UNIVERSIDADE DE SÃO PAULO

FACULDADE DE FILOSOFIA LETRAS E CIÊNCIAS HUMANAS

DEPARTAMENTO DE GEOGRAFIA

FERNANDO SILIANO REYES

O PAPEL DAS VIAS DE CIRCULAÇÃO NA COESÃO TERRITORIAL DO ESTADO BOLIVIANO: DA AUDIÊNCIA DE CHARCAS À BOLÍVIA DE 1971 
UNIVERSIDADE DE SÃO PAULO

FACULDADE DE FILOSOFIA LETRAS E CIÊNCIAS HUMANAS

DEPARTAMENTO DE GEOGRAFIA

\title{
O PAPEL DAS VIAS DE CIRCULAÇÃO NA COESÃO TERRITORIAL DO ESTADO BOLIVIANO: DA AUDIÊNCIA DE CHARCAS À BOLÍVIA DE 1971
}

\author{
Fernando Siliano Reyes
}

\begin{abstract}
Dissertação apresentada ao Programa de Pós-Graduação em Geografia Humana como parte dos requisitos necessários para a obtenção do título de mestre pelo Departamento de Geografia da Faculdade de Filosofia, Letras e Ciências Humanas da Universidade de São Paulo. Área de concentração: Geografia Humana.
\end{abstract}

Orientador: Prof. Dr. André Roberto Martin

São Paulo 


\section{Fernando Siliano Reyes}

\section{O PAPEL DAS VIAS DE CIRCULAÇÃO NA COESÃO TERRITORIAL DO ESTADO BOLIVIANO: DA AUDIÊNCIA DE CHARCAS À BOLÍVIA DE 1971}

Dissertação apresentada ao Programa de Pós-Graduação em Geografia Humana como parte dos requisitos necessários para a obtenção do título de mestre pelo Departamento de Geografia da Faculdade de Filosofia, Letras e Ciências Humanas da Universidade de São Paulo. Área de concentração: Geografia Humana.

São Paulo

2010

BANCA EXAMINADORA 


\section{Cantar}

Mi patría tíene montañas no mar. Olas de trigo y trigales, no mar. Espuma azul los pinares, no mar. Cielos de esmalte fundido, no mar. y el coro ronco del viento sin mar. 
Aos meus pais Francisco e Olga, que me ensinaram a buscar sempre a verdade.

À minha esposa Keiko, pelo amor, pelo apoio contínuo e por tudo o mais. Aos meus filhos Luísa e André, por me darem esperanças ao futuro. 


\section{Agradecimentos}

Quando temos ao nosso lado pessoas especiais, tudo fica mais fácil. Escrever esta dissertação não seria possível se eu não tivesse pessoas que, de uma maneira ou de outra, me auxiliaram.

Ao meu orientador, professor André Roberto Martin, que acreditou em mim, no meu trabalho e permitiu meu retorno à academia.

Ao professor Antônio Carlos Robert Moraes, pelos ensinamentos, pelas formulações teóricas e indicações bibliográficas que muito me ajudaram na construção deste trabalho.

À professora Mônica Arroyo, pelas muitas indicações de caminhos a serem seguidos.

Aos colegas Eduardo e Matheus, pela oportunidade de discutir as questões relativas à Bolívia, sempre em alto nível.

Ao amigo Maurício sempre me presenteando com suas valiosas críticas construtivas.

Aos amigos Edson, Rose, Wladimir, Vagner, Rosângela, Ana, Mônica, Renato, Gabeira, Ollitta, Fernando, Andréa e Edna pela camaradagem, sempre presentes, sem nunca pedirem nada em troca, a não ser a amizade.

À Tokiko e à Satiko, pela confiança no meu trabalho.

À Cássia, ao Félix, à Gezilde e à Juliana, pelo apoio fraternal e pelo carinho.

Ao pai Francisco e à mãe Olga, pela força, confiança e ensinamentos para eu me tornar um verdadeiro homem.

À Luísa e ao André, filhos mais que especiais que souberam, pacientemente, trocar os momentos em que poderíamos estar juntos.

E à Keiko, luz do meu caminho, o meu ombro amigo e companheiro, sempre presente, sempre incentivando, sempre apoiando, sempre disposta a ajudar para que este trabalho pudesse ser realizado.

A todos, o meu sincero, eterno e respeitoso agradecimento. 


\section{RESUMO}

Para entendermos o papel que as vias de circulação desempenharam na tentativa de dar coesão ao território boliviano, buscamos entender a ocupação do espaço andino desde a chegada dos espanhóis no território pré-boliviano, nas terras altas de Potosi. Também tentamos analisar os caminhos construídos a partir dessa ocupação, seja para o escoamento da prata, seja para o abastecimento da população que orbitava ao redor do complexo mineiro.

No decorrer da história da Bolívia independente, a circulação foi um dos motes da tentativa de unificação espacial com o Peru, comandada pelo general Andrés de Santa Cruz, uma vez que, na primeira metade do século XIX, alcançar o litoral boliviano era uma tarefa extremamente difícil, em face da inexistência de técnicas que tornassem menos dispendiosa a transposição da escarpa andina.

A guerra com o Chile, no final do século XIX, ainda hoje desperta sentimentos nacionalistas na população boliviana em função da perda de todo o seu território voltado para o Pacífico. A amputação de sua saída para o mar fez com que o governo boliviano exigisse do vencedor Chile a construção de uma estrada de ferro. Esta ligaria o país a um porto no Pacífico, a fim de seu comércio internacional não fosse sufocado e sua economia arruinada, devido a sua condição mediterrânea.

A disputa com o Brasil pelo território do Acre levou a Bolívia, mais uma vez, a pensar em uma solução circulatória que permitisse o escoamento da borracha, uma mercadoria então cobiçada no mercado internacional. No acordo entre os dois países, o Brasil se comprometeu a construir uma estrada de ferro para escoar a mercadoria boliviana pelos rios da bacia amazônica.

A guerra do Chaco, disputada com o Paraguai, cujo motivo teria sido uma disputa por petróleo, na realidade, foi uma tentativa de o governo boliviano alcançar o Atlântico utilizando o rio Paraguai. A derrota fez com que a Bolívia conseguisse acessar o Oceano Atlântico por intermédio da construção de uma ferrovia entre Santa Cruz de la Sierra e Corumbá, na fronteira com o Brasil, e de lá até o porto de Santos. Além dessa alternativa, a Bolívia também se 
utilizou do transporte ferroviário para alcançar o Atlântico, via Argentina, chegando até o porto de Buenos Aires.

A violenta derrota boliviana na guerra do Chaco abriu cicatrizes que culminaram na Revolução Nacionalista de 1952. O governo nacionalista estatizou as ferrovias e criou uma empresa estatal para cuidar das rodovias da Bolívia, porém, ao incentivar a construção de estradas de rodagem, a ingerência estadunidense inviabilizou a efetiva integração territorial boliviana por vias férreas e, por extensão, a ligação ferroviária entre os oceanos Atlântico e Pacífico, pela união dos portos de Arica no Chile e de Santos no estado de São Paulo.

\section{PALAVRAS-CHAVE}

Bolívia, circulação, conflito, integração, geopolítica. 


\begin{abstract}
To understand the role played by the circulation ways so as to provide cohesion to the Bolivian territory, one must understand the occupation of the Andean space since the arrival of the Spanish at the pre-Bolivian territory, in the high lands of Potosi. We have also tried to analize the ways built after such occupation, whether for the flow of silver, or for the provisioning of the population orbiting the mining complex.

In the course of independent Bolivia's history, circulation was one of the mottos in the search for spatial unification with Peru, commanded by General Andrés de Santa Cruz, seeing that it was such an extremely hard task to reach the Bolivian sea coast in the first half of the $19^{\text {th }}$ century, due to the inexistence of techniques which could make the transposition of the Andean scarp less costly.
\end{abstract}

The war against Chile at the end of the $19^{\text {th }}$ century still arouses nationalistic feelings in the Bolivian people today, for the loss of their whole territory facing the Pacific. The amputation of their exit to the sea made the Bolivian government demand that a railroad connecting Bolivia to a port in the Pacific should be built by the winner - Chile. Thus, international trading would not be suffocated and consequently, Bolivian economy would not be ruined by their mediterranean condition.

The dispute against Brazil for the territory of Acre once again forced Bolivia to come up with a circulatory solution so as to enable the flow of latex, such a coveted raw material in international markets by then. It was agreed that Brazil would build a railroad for the flow of Bolivian commodities along the Amazon watershed.

The Chaco War, whose motto was the dispute for oil against Paraguay, was, in fact, another Bolivian attempt to reach the Atlantic through the Paraguay river. The defeat enabled Bolivia to access the Atlantic after the construction of a railroad connecting Santa Cruz de la Sierra to Corumbá, in the borderline with Brazil, and from that point to the Port of Santos. Besides this alternative, Bolivia also used railways to reach the Atlantic through Argentina, up to the Port of Buenos Aires. 
Bolivia's huge defeat in the Chaco War has left scars which culminated in the nationalistic revolution of 1952 . The nationalistic government took over all railways and created a state-owned company to manage Bolivian roads. However, North-American interference and stimulus to the construction of highways precluded an effective integration of the Bolivian territory through railroads and, thus, the railway connection between the Atlantic and the Pacific, uniting the Port of Arica in Chile and the Port of Santos in São Paulo.

\section{KEY-WORDS}

Bolivia, circulation, conflict, integration, geopolitics. 


\section{LISTA DE MAPAS}

Mapa 1. Localização da Bolívia na América do Sul. 18

Mapa 2. Departamentos bolivianos 21

Mapa 3. Rota de escoamento da prata 32

Mapa 4. Território original da República da Bolívia em 1825 43

Mapa 5. Acessos da Bolívia para o oceano Pacífico em 1825.

Mapa 6. Ferrovias da Bolívia no final do século XIX .80

Mapa 7. Eixos econômicos da Bolívia .112

Mapa 8. Estrada de ferro Santa Cruz de la Sierra - Santos 120

Mapa 9. Rede ferroviária boliviana 124

Mapa 10. Perdas territoriais da Bolívia 131

Mapa 11. Mapa do território atual da Bolívia. 132

\section{Lista de fotografias}

Fotografia 1. Cachoeira de Santo Antônio, no rio Madeira 75

Fotografia 2. Restos dos trilhos da ferrovia Madeira-Mamoré .86 


\section{SUMÁRIO}

APRESENTAÇÃO ……………………………............ 13 -

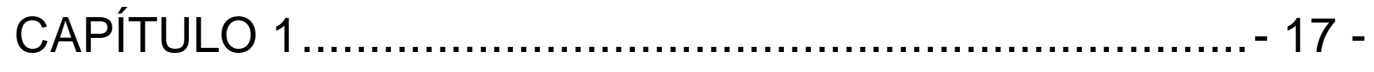

UM PAÍS CHAMADO BOLÍVIA........................................ 17 -

1.1 A OCUPAÇÃO HUMANA ………....................... 21 -

1.2 A OCUPAÇÃO ESPANHOLA ………………....... 23 -

1.3 O SURGIMENTO DO ESTADO BOLIVIANO ....... 38 -

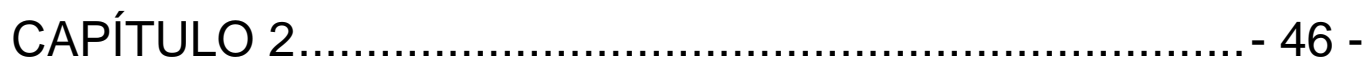

A GUERRA DA CONFEDERAÇÃO PERU-BOLIVIANA ... - 46 -

2.1 A GUERRA DO PACÍFICO .................................. 51 -

2.2 A QUESTÃO DO ACRE..................................... 61 -

2.3 A GUERRA DO CHACO .................................. 86 -

2.3.1 A QUESTÃO DO PETRÓLEO ........................ 92 -

2.3.2 O FIM DO CONFLITO ............................... 95 -

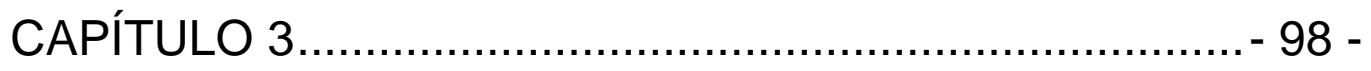

A REVOLUÇÃO INACABADA DE 1952 ............................ 98 -

3.1 O ORIENTE BOLIVIANO ................................. 110 -

3.2 O INTERESSE DO BRASIL E DA ARGENTINA - 114 CONSIDERAÇÕES FINAIS......................................... 128 -

REFERÊNCIAS BIBLIOGRÁFICAS .............................. 136 - 


\section{APRESENTAÇÃO}

A Bolívia, para o senso comum e a indústria cultural, tem sido sinônimo de pobreza e miséria e, nos últimos tempos, uma miséria de feições nitidamente indígenas e de experimentos populistas. Segundo Hofmeister (2004), a Bolívia pode ser considerada o país mais pobre da América do Sul e o com maior instabilidade política do continente. Desde sua independência, em 1825, pode-se contar mais de duzentos golpes de Estado e trocas de governo com uso de força. Constatações importantes sobre o "estado das coisas" na Bolívia.

Contudo, o conhecimento não se faz apenas por constatações ou impressões, mas pelo avanço da análise do real, que precisa ser desvelado, ou seja, desnaturalizado e historicizado. Assim, como qualquer sociedade, a Bolívia não é o ponto de chegada da reflexão geográfica, mas o ponto de partida para a compreensão de uma intrincada relação, de uma sociedade nacional com o espaço e o tempo do capitalismo mundializado.

A formação da economia-mundo capitalista estabeleceu elos intricados entre as terras e mares do globo, cujo processo foi assimétrico e nada harmonioso. A expansão do capital expresso no desenvolvimento desigual e combinado espalhou a mercantilização, a expropriação e, de acordo com Harvey (2006), o desapossamento dos homens e da natureza.

Nesse processo, o surgimento de Estados Nacionais foi fundamental, pois essas novas entidades políticas definiram e organizaram espaços territoriais destinados ao processo de acumulação e valorização de capital. Contudo, não se pode esquecer de que nacional/internacional se interpenetram e se determinam mutuamente. Dessa forma, os Estados Nacionais se constituem tanto uma interface da expansão global do capitalismo e das áreas de atuação das camadas burguesas em seu exercício de hegemonia, quanto do desapossamento/enfrentamento dessas classes subalternas. Assim, a expansão do capitalismo também é a expansão de formas específicas de organizar o espaço. 
No caso concreto e particular da Bolívia, isso implicou, historicamente, a valorização/desvalorização de determinadas porções de seu território ${ }^{1}$ pelas forças que expressam o desenvolvimento e o desdobramento das relações do modo de produção capitalista. Nesse sentido, Costa Neto enfatiza que "a Bolívia estruturou-se, social e economicamente, sobre três pilares básicos de sustentação: a mineração de estanho, no Oeste do país; a economia da borracha, no Norte; e a exploração de petróleo e gás natural, na região Sudeste." (COSTA NETO, 2005, p. 87)

Para a viabilização do comércio exterior e do próprio território boliviano, a questão da circulação transformou-se em prioridade, em função da própria configuração territorial da Bolívia que, num primeiro momento, tem sua saída para o oceano pacífico dificultada pelas imposições do relevo, porém, quando a técnica permite a superação dessas dificuldades, o país perde sua condição marítima.

A partir dessa ótica, o presente trabalho elege como foco a compreensão do papel das vias de circulação na integração territorial do Estado boliviano. Entendemos que essa circulação se desenvolve de acordo com as determinações do modo de produção capitalista relacionadas à Divisão Territorial do Trabalho e ao processo de espacialização das relações sociais.

Contudo, com o passar do tempo, novas técnicas são incorporadas no sentido de suprir as necessidades próprias de uma sociedade voltada para a valorização do capital e suas formas de sociabilidade.

Assim, no Estado boliviano, a construção de caminhos adquire uma importância ímpar, pois sua condição mediterrânea impõe ao país a necessidade de ligações com o mercado externo, utilizando para isso dos territórios de países vizinhos. Além disso, a busca da coesão interna torna-se condição fundamental para a existência do próprio Estado, vilipendiado nos conflitos externos em que esteve envolvido.

Para atingir os objetivos propostos, delimitamos o tempo histórico do trabalho entre a ocupação espanhola, no início do século XVI até 1971, ano que encerra o ciclo de governos nacionalistas ligados ao Movimento

\footnotetext{
${ }^{1}$ O conceito "Território" será utilizado neste trabalho na perspectiva de Moraes. Para este autor, "o território deve ser entendido como uma materialidade e como uma representação e/ou como um projeto de ocupação prática de porções da superfície terrestre e de sua legitimação simbólica." (2009, p. 29)
} 
Nacionalista Revolucionário (MNR), oriundos da revolução de 1952. Para tanto, dividimos esta dissertação em 3 capítulos.

No primeiro capítulo, trabalhamos as características físicas e humanas da Bolívia, sua localização, seus aspectos físicos e climáticos, sua regionalização e divisão da população. Procuramos também descrever a força da herança indígena na construção da identidade dos povos que compõem o país. Recorremos à ocupação espanhola e ao início do Sistema-mundo moderno-colonial para compreendermos:

a) a herança espanhola no que tange à construção de vias de circulação para a articulação mais eficaz com a metrópole;

b) a apropriação do espaço potosino e das áreas vizinhas, necessárias para a existência de Potosi;

c) a construção do Estado boliviano, cujo território era, após a independência, aproximadamente duas vezes maior do que hoje, inclusive com parte de seu território alcançando o oceano Pacífico.

No segundo capítulo, trabalhamos com as disputas externas, nas quais o Estado boliviano esteve envolvido, desde a tentativa de formar uma grande república com a junção territorial com o Peru e o surgimento da Confederação Peru-Boliviana, um ensaio de alargar as possibilidades de acesso à costa do Pacífico. Além disso, veremos a Guerra do Pacífico, na qual a Bolívia perdeu todo seu litoral para o Chile, necessitando a partir daí de uma ferrovia que não asfixiasse seu comércio internacional.

$\mathrm{Na}$ sequência tratamos da questão do Acre, território perdido para o Brasil, em meio a uma disputa internacional pela posse de um território produtor de borracha, material importante para os países centrais da época. A perda do Acre mais uma vez faz a Bolívia requerer a construção de uma ferrovia para escoar, via bacia amazônica, a produção de borracha que restou em seu território.

Finalizamos o segundo capítulo discutindo o mais cruel conflito externo em que a Bolívia se envolveu, a Guerra do Chaco, disputada contra o Paraguai. Paradoxalmente, apesar da derrota sofrida, esse conflito fez surgir o embrião de uma consciência nacional.

O terceiro capítulo trata da Revolução de 1952, realizada com contornos de uma revolução socialista, mas apropriada pela elite pequeno-burguesa, que 
foi obrigada a fazer concessões à classe trabalhadora, principalmente no que tange à privatização da principal riqueza boliviana, as minas de metais preciosos.

Em seguida, escrevemos sobre o oriente boliviano, uma área que até meados do século XX não estava integrada ao Estado boliviano e que, pela ação estatal, passa a ter uma importância cada vez maior no espaço econômico boliviano.

Finalizando o terceiro capítulo, procuramos esclarecer o interesse do Brasil e da Argentina em ter a Bolívia como área de influência, ambos se utilizando da construção de vias de circulação para integrar o oriente boliviano no sentido de consolidar a hegemonia sobre esse país. 


\section{CAPÍTULO 1 \\ UM PAÍS CHAMADO BOLÍVIA}

A República da Bolívia é um país mediterrâneo, encravado na Cordilheira dos Andes, na porção central da América do Sul. Possui uma área de $1.098 .581 \mathrm{~km}^{2}$ e situa-se entre os meridianos $57^{\circ} 26^{\prime} \mathrm{W}$ e $69^{\circ} 38^{\prime} \mathrm{W}$ e entre os paralelos 9० 38' S e 220 53' S (Mapa 1).

Limita-se ao norte e a leste com o Brasil, ao sul com a Argentina, a oeste com o Peru, a sudeste com o Paraguai e a sudoeste com o Chile.

É cortada pela Cordilheira dos Andes, que percorre o oeste do país em duas cadeias paralelas. Entre elas, encontra-se um altiplano árido e quase sem vegetação. Nesse planalto está instalada a maior parte da população boliviana, principalmente na capital La Paz e na cidade vizinha de El Alto.

Com relação a sua posição geográfica, a Bolívia pode ser considerada o centro integrador da América do Sul, pois é o único país americano que possui pedaços de seu território na Cordilheira dos Andes, nas bacias hidrográficas amazônica e platina.

Ainda no que tange à posição geográfica, a Bolívia poderia ser o grande centro conector para uma futura política de integração entre os países sulamericanos, já que seu território poderia ser o centro de convergência de uma rede de transportes rodoviários e ferroviários vinculados a redes de transportes nacionais. Além disso, poderia ser o eixo de ligação entre um porto fluvial no Prata e outro no Amazonas, bem como o centro da ligação entre o Oceano Pacífico e o Atlântico, proporcionando, dessa forma, o trânsito mais rápido para o comércio entre os países latino americanos e seus parceiros transcontinentais. 


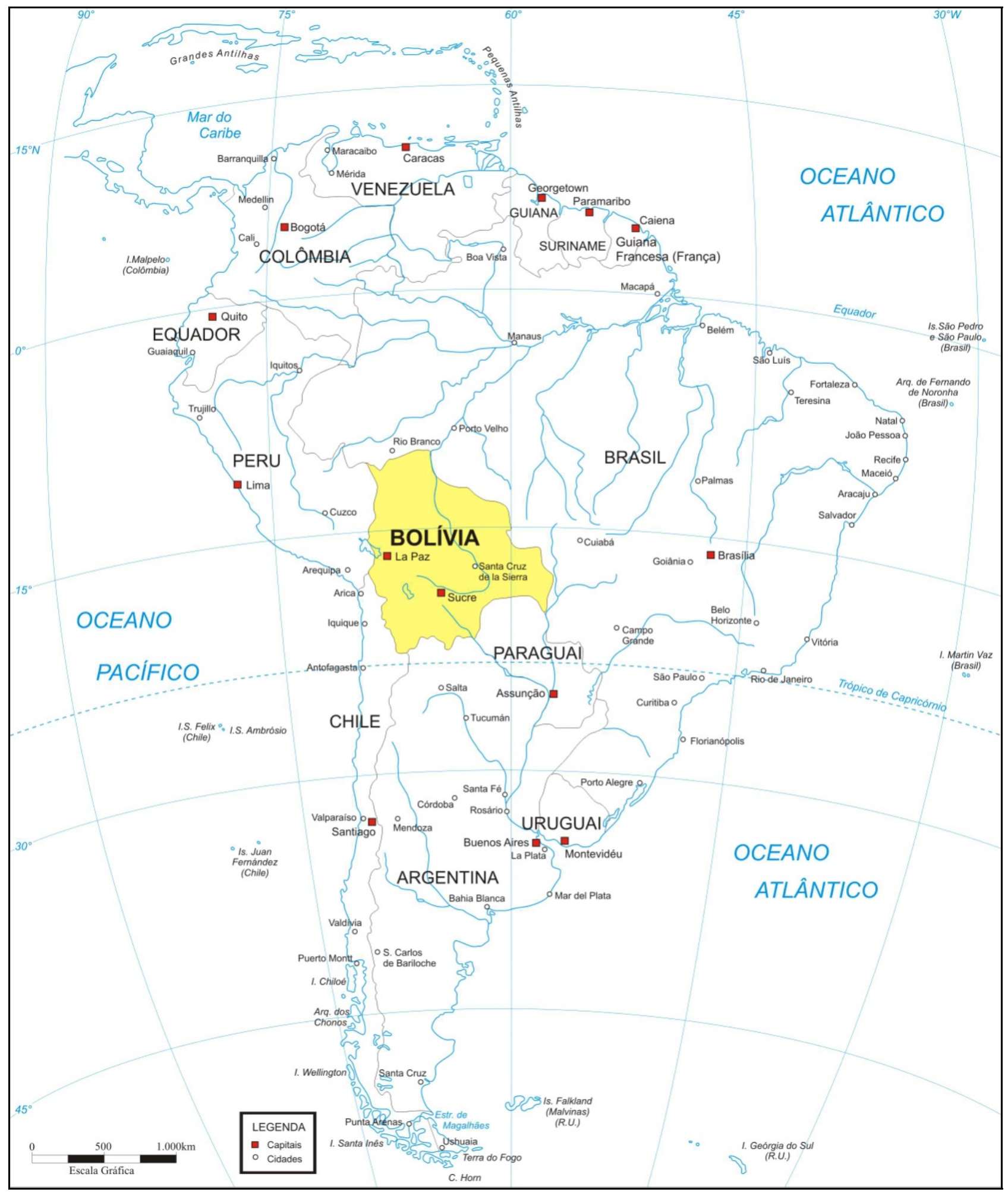

Mapa 1

Localização da Bolívia na América do Sul (BOCHICCHIO, 2003, p. 43 - adaptado) 
Segundo dados do Instituto Nacional de Estadística², órgão do governo boliviano, o território do país é dividido em três grandes zonas geográficas. A zona de maior extensão é chamada de llanos (planícies), que corresponde a $59 \%$ do território boliviano (aproximadamente $648.000 \mathrm{~km}^{2}$ ) e abrange os departamentos de Pando, Beni e Santa Cruz. Localiza-se ao norte da Cordilheira Oriental, estendendo-se desde a base da Cordilheira dos Andes até o rio Paraguai. Nessa região predominam as planícies, que possuem uma vegetação exuberante.

Em seguida, destaca-se a Zona Andina, abrangendo em torno de $28 \%$ do território (aproximadamente $307.000 \mathrm{~km}^{2}$ ), compreendendo os departamentos de La Paz, Oruro e Potosi. Situa-se a mais de 3.000 metros de altitude, entre as Cordilheiras Ocidental e Oriental. É nessa zona que se encontra o lago mais alto do mundo, o Titicaca, situado a 3.810 metros de altitude e com uma extensão de $8.100 \mathrm{~km}^{2}$.

Por fim, a Zona Subandina, intermediária entre o altiplano e os llanos orientais, ocupa cerca de $13 \%$ do território da Bolívia (aproximadamente $145.000 \mathrm{~km}^{2}$ ), nos quais se localizam os departamentos de Chuquisaca, Cochabamba e Tarija. É nessa zona que se encontram os vales andinos e os yungas (uma zona de transição entre as terras altas, secas e áridas, e terras baixas e úmidas), a aproximadamente 2.500 metros de altitude.

O território boliviano está inserido em três grandes bacias hidrográficas. A bacia do Norte ou Amazônica, cujos principais rios bolivianos que a constituem são Madre de Dios, Orthon, Abuná, Beni, Yata, Mamoré e Guaporé ou Itenéz. A bacia Central ou Lacustre, formada pelos lagos Titicaca e Poopó e pelo rio Desaguadero. Por fim, a bacia do Sul ou da Prata, formada pelos rios Paraguay, Pilcomayo e Bermejo.

Apesar de a Bolívia estar localizada entre o Trópico de Capricórnio e a Linha do Equador, portanto, um país tropical, o clima muda substancialmente em função do relevo. Na parte andina o frio é intenso, as chuvas são escassas e no alto das montanhas persistem as chamadas neves eternas. Na região da planície o clima é tropical, com chuvas concentradas no verão e as temperaturas são sempre elevadas.

\footnotetext{
${ }^{2}<$ http://www.ine.gov.bo>. Acesso em 14 out. de 2008.
} 
O Estado boliviano (Mapa 2) é dividido em nove departamentos (Pando, Beni, Santa Cruz, Chuquisaca, Tarija, Potosi, Cochabamba, Oruro e La Paz), 112 províncias e 327 municípios. A cidade de Sucre é a capital constitucional e a sede do governo fica em La Paz.

Segundo o censo boliviano de $2001,59 \%$ da população boliviana $(4,7$ milhões) é composta por pobres. Em torno de $42,2 \%$ da população total vive com menos de dois dólares por dia. Cerca de 64\% são indígenas (a maioria quéchua e aymará) ${ }^{3}$, concentradas, até a década de 1980, nas áreas rurais. Os quéchuas concentram-se na região subandina e os aymarás na região andina. Vale ressaltar a participação, na população boliviana, de índios guaranis, concentrados principalmente na planície.

Apesar de serem descendentes diretos dos primeiros ocupantes do atual território boliviano, essa população indígena sempre esteve à mercê dos interesses econômicos e políticos da burguesia nacional e do imperialismo, ora britânico ora estadunidense. Atualmente, são os capitalistas brasileiros, argentinos, croatas, russos e japoneses, que vislumbram a Bolívia como um espaço de acumulação de capital. Pelo fato de serem camponeses indígenas (que carregam heranças espanholas coloniais), ou apenas camponeses (sem o ranço colonial) ${ }^{4}$, o que os une é a pobreza e, de acordo com Harvey (2006), potenciais expropriados para a acumulação do Modo Capitalista de Produção, no papel de produtores espoliados.

\footnotetext{
${ }^{3}<$ http://www.ine.gov.bo>. Acesso em 14 out. de 2008.

${ }^{4}$ Mignolo (2003, pp. 276-277) resgata os estudos de Rivera Cusicanqui feitos na publicação "Oprimidos pero no Vencidos" de 1984 onde a autora diferencia o "camponês-aimará ou "camponês-quíchua", que indicam as tensões de classe e etnia, resgatando a opressão colonial, do simples "camponês", fruto do capitalismo sem fricções étnicas.
} 


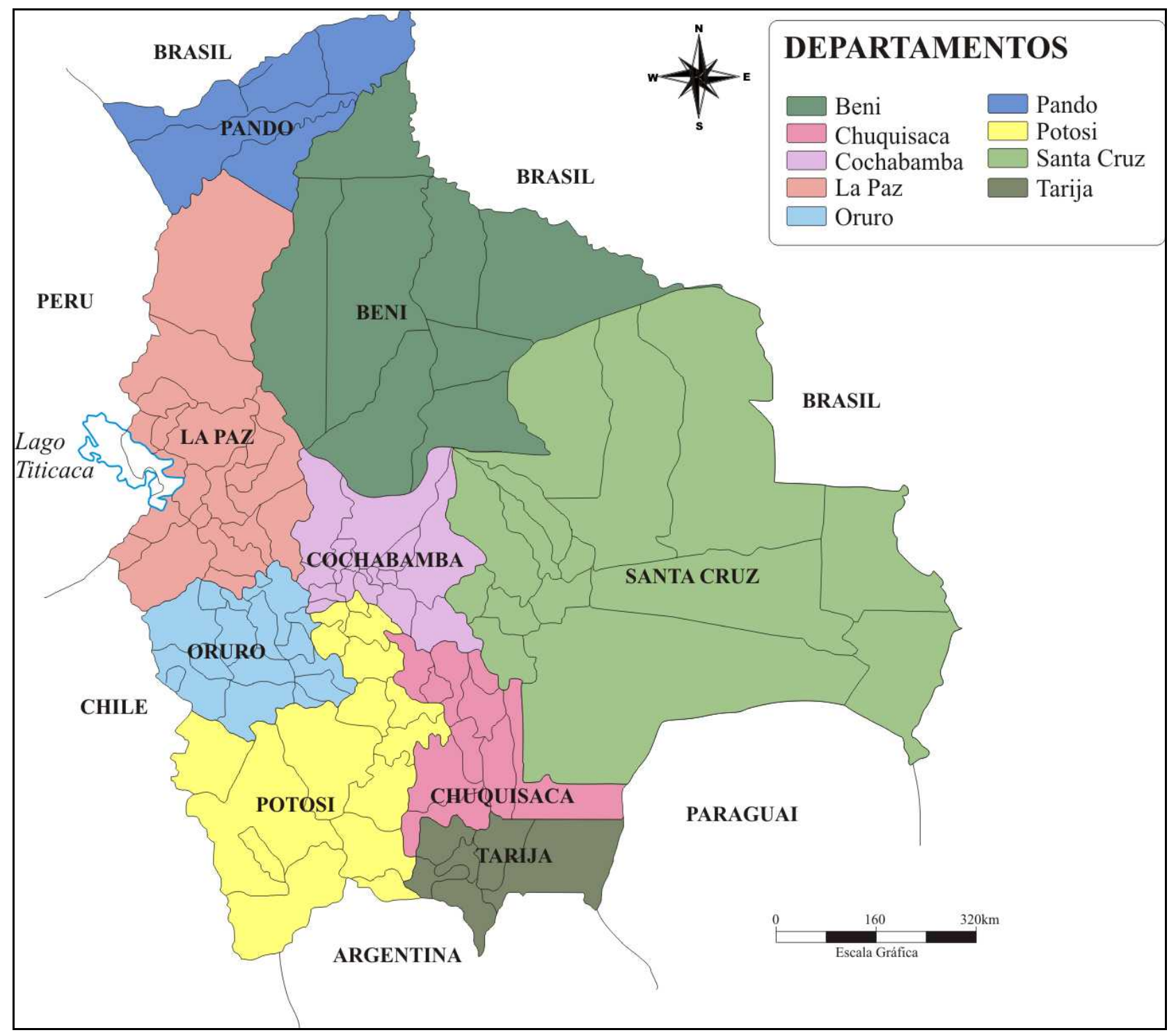

\section{Mapa 2}

Departamentos bolivianos (GALLUP, 2005, p. 111 - adaptado)

\subsection{A OCUPAÇÃO HUMANA}

Na região andina há resquícios de civilização de cerca de 20.000 anos, mas segundo Klein (2004), a primeira grande civilização a se desenvolver no altiplano boliviano foi a civilização Tiahuanaco, cuja capital homônima foi erguida na margem sul do lago Titicaca, a partir do ano 600 a.C.. Lá 
desenvolveram técnicas agrícolas de cultivo em terraços e nos planaltos, até desaparecer por volta de 1200 d.C..

Posteriormente à civilização Tiahuanaco, desenvolveu-se próximo ao Lago Titicaca o reino dos Aymarás, que migraram para Tiahuanaco após sua derrocada. Os Aymarás, também chamados de collas, eram divididos em sete grandes nações. Como observa Klein, "O desenvolvimento dos reinos dos Aymarás assinalou propriamente o início da história boliviana. Eles dominaram os planaltos centrais desde o fim do século XII até a chegada dos espanhóis no século XVI" (KLEIN, 2004, p. 14). Dedicavam-se, principalmente, à criação de Ihamas e alpacas e praticavam uma agricultura extensiva.

Os Quéchuas também emergiram após o colapso da civilização Tiahuanaco. O Império Inca ${ }^{5}$, emergido em Cuzco, ao contrário dos aymarás, era expansionista e estendeu seu império desde o sul da atual Colômbia até o norte do atual Chile. Eles estenderam a influência de seu império sobre o reino dos aymarás, em 1460, confinando-os em uma província de nome Kollasuyo, uma das quatro unidades administrativas do Império Inca. No olhar de Klein, essa influência não significou a incorporação dos aymarás, já que mantiveram sua organização social e política, pagando apenas tributos aos quéchuas. A derrocada dos aymarás aconteceu em 1470, não de modo pacífico. Derrotados, perderam a independência para os quéchuas, porém, a língua aymará não conseguiu ser derrotada e é falada até hoje.

A população pré-colombiana que ocupava as planícies do leste era composta em sua maioria por índios, falava o idioma guarani e pertencia às etnias moxo e chiquitanos. Os povos do leste não foram dominados pelo Império Inca, mesmo os espanhóis tiveram enormes dificuldades para fazê-lo. Segundo informações contidas no sítio do Instituto Nacional de Estadística da Bolívia ${ }^{6}$, apenas em 1675 dois padres espanhóis partiram de Lima até Santa Cruz e de Santa Cruz para a tribo dos moxos, em Guapay, fundando em 1682 a missão de Nossa Senhora do Loreto e em 1686 fundaram a missão da Santíssima Trindade, que hoje é a capital do departamento de Beni.

\footnotetext{
${ }^{5} \mathrm{O}$ nome inca refere-se a império e não, em termos restritos, aos seus habitantes. (CHASTEN, 2001, p. 29)

${ }^{6}<$ http://www.ine.gov.bo> (acesso em 14 de outubro de 2008).
} 
Ainda segundo o Instituto Nacional de Estadística, a administração do oriente foi confiada pelos espanhóis, no século XVII, aos padres jesuítas, que levantaram a primeira construção nas terras dos chiquitanos, fundando a cidade de São Francisco Xavier, nas proximidades do rio Paraguai, além das missões de Moxos, Chiquitos, Mainas, Putumaio e Orenoco que eram interligadas por redes de trilhas que se cruzavam.

O contato com indígenas afastados das minas de prata localizadas no altiplano, principalmente nos vales da vertente oriental da Cordilheira dos Andes, era realizado sobretudo por religiosos. Conforme Caio Prado Junior (1994), os religiosos dirigiam-se para os lugares onde inexistiam os minerais alvo da ambição metropolitana. Portanto, a conquista espiritual seria mais fácil, pois não haveria disputa, num primeiro momento, entre os interesses religiosos de um lado e os econômicos de outro lado, ou seja, a necessidade de ter braços para as minas de prata do altiplano.

Em 1767, com a expulsão dos jesuítas, essa área ficou à mercê dos bandeirantes brasileiros, que buscavam riquezas minerais e índios para escravizarem, causando um esvaziamento progressivo no oriente boliviano.

\subsection{A OCUPAÇÃO ESPANHOLA}

A conquista espanhola do Império Inca foi obra de Francisco Pizarro, numa época de declínio do império. Após a morte do imperador Huayna Capac, em 1527, seus filhos Huascar e Atahualpa travaram uma briga pela sucessão.

De acordo com Chasteen,

Pizarro tinha apenas 168 espanhóis, mas infelizmente para os incas, o imperador reinante e seu sucessor haviam morrido subitamente da epidemia que, alastrando-se pelas rotas comerciais à frente de Pizarro, devastou a família dirigente inca, gerando uma crise de sucessão pouco antes da chegada dos espanhóis. Desastradamente, uma guerra civil inca havia eclodido. Atahualpa comandava um lado e seu irmão, Huascar, o outro. O ardiloso Pizarro conseguiu jogar os dois lados um 
contra o outro, obtendo a derradeira vitória para si. (CHASTEEN, 2001, p. 45)

Embora Atahualpa tenha derrotado Huascar, não havia ainda consolidado plenamente seu poder quando da chegada dos espanhóis, comandados por Pizarro, em 1532.

Entre os aymarás também houve resistência à ocupação espanhola, porém, a tarefa se mostrou bastante difícil, pois além de enfrentar o forte exército espanhol, tinham de enfrentar também uma parcela de seu próprio povo que estava colaborando com os conquistadores.

Elliott (2008) escreve que, em novembro de 1533, a cidade de Cuzco, a principal cidade Inca, foi tomada pelos espanhóis, destruindo o império. A intencionalidade espanhola era manter a estrutura social incaica para carrear os lucros para a metrópole.

Pela disputa do butim, houve disputas entre os próprios espanhóis, notadamente entre os exploradores Francisco Pizarro e Diego de Almagro. Os remanescentes incas tentaram uma reação, comandada por Manco Inca, mas foram derrotados, quando em 1572 o último reduto inca, localizado em Vilcabamba, foi derrotado pelas forças espanholas. As disputas entre os próprios espanhóis eram tão violentas que Diego de Almagro foi assassinado em 1538, e Francisco Pizarro foi morto pelos seguidores de Almagro, em 1542.

A ocupação espacial do território incaico seguiu a lógica sistêmica mercantilista, na qual o acúmulo de metais preciosos era condição fundamental do processo de conquista e dominação dos territórios encontrados. Para Dussel,

Nunca houve, empiricamente, História Mundial até 1492 (como data da decolagem do "Sistema-mundo"). Anteriormente a essa data, os impérios ou sistemas culturais coexistiam entre si. Somente com a expansão portuguesa a partir do século $\mathrm{XV}, \mathrm{a}$ chegada ao Extremo Oriente no século XVI, e com o descobrimento da América hispânica, todo o planeta torna-se o 'lugar' de 'uma só' história mundial. (DUSSEL, 2005, p. 61) 
Dessa forma, tanto o atual sistema mundial quanto a América nasceram no final do século XV. Nesse sentido, não conseguiremos entender o avanço do modo de produção capitalista sem entender os processos de colonização da América, como apontou Moraes em sua análise sobre a formação dos territórios coloniais:

A colonização americana inicia-se com a instalação de enclaves, que atuam como bases de difusão do processo. Esses evoluem para regiões quando passam a abarcar espaços mais dilatados, que abrigam assentamentos e fluxos permanentes e consolidados. Tais conjuntos regionais, em suas articulações e complexizações, acabam por conformar efetivos territórios na América colonial, que apresentam uma divisão interna do trabalho com zonas de produção especializadas. Tais organizações espaciais, dotadas de instalações e assentamentos (e de fundos territoriais), com sua lógica de disposição das atividades e equipamentos no espaço, emerge como um dos elementos significativos da "herança colonial" das formações periféricas.

Enfim, os territórios coloniais atuaram como as bases da construção dos territórios nacionais na América Latina. Por isso, entender a dinâmica que presidiu suas formações, e conhecer os arranjos sociais gerados em cada caso, aparecem como pressuposto para a explicação da história das sociedades latino-americanas. (MORAES, 2000, p. 23)

A partir da lógica de análise da constituição da economia-mundo, pensamos que, para uma melhor compreensão do objeto de estudo, é fundamental fazer um breve levantamento histórico da Bolívia, desde a ocupação desse espaço pelos espanhóis.

O Estado Nacional conhecido como Bolívia originou-se do espaço colonial dominado pela Espanha, do século XVI ao XIX. Como assinala Fernando Novais (2000), a colonização moderna representou a europeização das Américas e de outras áreas do planeta como resultado do expansionismo marítimo-mercantil, bem como a criação de espaços complementares ao 
processo de acumulação de capitais das áreas metropolitanas da nascente economia-mundo.

O poder metropolitano espanhol impôs suas determinações sobre a América Latina, por meio da sujeição manu militari dos povos e culturas indígenas estabelecidos no altiplano andino e na planície. Houve a destruição do Império Inca, contudo, certas estruturas indígenas relacionadas ao trabalho compulsório e a subordinação ao poder central foram mantidas devido a sua serventia para a constituição de uma economia colonial baseada em enclaves mineiro-exportadores.

A partir desses enclaves, desenvolveram-se regiões e um território colonial, segundo Gumucio:

Es en el altiplano y los valles interandinos dónde hoy vive la mayor parte de la población, y es allí dónde se formaron las altas culturas precolombinas de los quéchuas y aimaras y se asentaron las principales ciudades, como Chacras (hoy Sucre), La Paz, Cochabamba, Oruro y Potosí, y las explotaciones mineras. En el oriente fueron las ciudades de Santa Cruz, Trinidad, Riberalta y Cobija, y uma miríada de pueblos fundados por los jesuítas n los siglos XVI y XVII (GUMUCIO, 1996, pp. 14-15)

Moraes (2000) enfatiza a enorme importância da exploração da prata na organização do padrão da ocupação espacial da colônia e, principalmente, da importância fulcral de Potosi no processo de ocupação territorial por parte da Espanha.

Segundo Bakewell (2008), as primeiras fontes de prata foram encontradas em 1538 por Gonzalo Pizarro nas minas incas de Porco e, em 1545, em Potosi, seguido de outros achados menores nas proximidades. A

\footnotetext{
7 Tradução livre: É no altiplano e nos vales interandinos onde hoje vive a maior parte da polulação e é lá que se formaram as altas culturas pré-colombianas dos quéchuas e dos aimarás e assentaram as principais cidades, como Charquas (hoje Sucre), La Paz, Cochabamba, Oruro e Potosi, e a mineração. No oriente foram fundadas as cidades de Santa Cruz, Trinidad, Riberalta e Cobija, e uma série de povoados fundados pelos jesuítas nos séculos XVI e XVII.
} 
descoberta das reservas de prata em Potosi "representou um dos acontecimentos mais importantes da história americana. Esta vila foi durante muito tempo o coração econômico, a 'jóia do império', o impulsionador da economia colonial sul-americana". (PRODANOV, 2002, p. 37).

Dados contidos em Prodanov (2002) dão conta que, aproximadamente, 30.000 toneladas de prata foram extraídas das minas potosinas para abastecer a Espanha, financiando o mercantilismo europeu.

Num primeiro momento, a prata era retirada em veios que corriam praticamente na superfície, porém, em pouco tempo, a voracidade da extração levou a escavação de vários túneis no interior da montanha.

A necessidade premente de mão-de-obra fez que fosse colocada em prática, por volta de 1550, pelo vice-rei Dom Francisco de Toledo, a prática da mita, ou seja, o trabalho compulsório nas minas, realizado por índios do sexo masculino com idade entre dezoito e cinquenta anos.

Para Bakewell (2008), a descoberta de jazidas de mercúrio em Huancavelica (no atual Peru), no ano de 1563, também possui importância ímpar no mesmo processo de ocupação territorial.

De acordo com Moraes,

a ocupação segue um eixo que vai das minas de mercúrio de Huancavelica, trezentos quilômetros ao norte de Lima, passando por esta cidade, e avançando num sentido sul para a velha região mineira de Cuzco, até atingir o cerro de Potosi (a cerca de 2.000 quilômetros de Lima), a montanha de prata descoberta em 1545, a quatro mil metros de altitude. Tal rota latitudinal firma-se com a introdução da técnica do amálgama na extração mineira, em 1572, a qual torna Huancavelica 'condição de Potosi'. (MORAES, 2000, p. 203)

O mercúrio tornou-se fundamental para fazer a amalgamação com a prata. Na junção de ambos forma-se uma espécie de pasta. Ao mesmo tempo em que a prata se junta com o mercúrio, as impurezas se separam dessa mistura. A partir daí, a ela passa por um processo de aquecimento para 
separar o mercúrio da prata, garantindo a enorme produção desse último minério. Para sustentar tal afirmação, Bakewell escreveu que

A produção de Potosi cresceu quase seis vezes no período de 1575-1590, alcançando, em torno de 1592, não apenas o seu nível mais alto de todos os tempos, mas também um nível que excedeu o atingido por qualquer outro distrito mineiro em todo o período colonial. Nos anos de 1575-1600, Potosi produziu talvez a metade de toda a produção hispano-americana. Tal profusão de prata não teria vindo à tona sem a concomitante abundância de mercúrio de Huancavelica, que naqueles mesmos anos estava também produzindo como nunca havia feito. (BAKEWELL, 2008, pp. 140-141)

O processo de amalgamação também foi importante, segundo Wachtel (2008), pois os espanhóis puderam romper o controle técnico que os indígenas possuíam sobre a produção da prata, pois até então o método empregado era o chamado huayra (ou Guaíra), a tradicional fundição incaica baseada na energia eólica. A utilização do mercúrio fez com que as sobras da extração, que não podiam ser usados pelo método indígena, passaram a ser reaproveitadas no novo processo de amálgama, proporcionando um revigoramento da produção da prata.

Potosi, um local ermo de difícil acesso, situado a cerca de 4.000 metros acima do nível do mar e encravada no alto da Cordilheira dos Andes pode ser considerada, segundo Pierre Vilar (1981) um dos "lugares históricos do capitalismo", devido a enorme quantidade de prata ali encontrada. Em pouco tempo a população cresceu abruptamente, chegando a ter aproximadamente 160.000 habitantes, segundo Morse (2008), e transforma-se na maior cidade do hemisfério sul. Para abastecê-la, tudo vinha de fora, nada era ali produzido, nada deveria tirar a atenção do que mais importava em Potosi: a extração da prata.

As estradas e o comércio expandiram-se rapidamente à medida que se desenvolveram novos circuitos econômicos, energizados pela mineração. Roupas, vinho e ferro da 
Espanha, escravos da África, sedas e especiarias do Oriente fluíam para as vilas mineiras e para pagar por tudo isso, enormes quantidades de metal precioso, principalmente prata, começaram a fluir na direção oposta. (BAKEWELL, 2008, p. 102)

Bakewell (2008) salienta que a produção de mercúrio em Huancavelica entrou em declínio a partir de 1595, devido ao violento processo de exploração ali realizado. Porém, como o uso da amálgama estava enraizado na extração da prata, proporcionando ganhos em escala, os espanhóis se valeram da importação do mercúrio oriundo principalmente de Almadén, na Espanha, mas também era importada de Idrija, na atual Eslovênia, que na época vivia sob os auspícios dos Hasburgos.

Os processos de mineração em Potosi também serviram para o desenvolvimento de um dinâmico mercado interno, ligando e dando vida a diversas localidades dentro do território colonial espanhol.

As cidades de Cochabamba, Tarija e Tomina, fundadas respectivamente em 1571, 1574 e 1575, encarregaram-se de abastecer com gêneros alimentícios a população do altiplano, principalmente, trigo e milho. La Paz (Ciudad de Nuestra Señora de La Paz), fundada em 1548, especializou-se no cultivo de raízes de coca, na criação de animais e prosperou graças à condição de ponto de parada no caminho entre as minas de Potosi e o litoral e, posteriormente, por estar na rota entre Lima e Buenos Aires, enquanto Santa Cruz abastecia a mesma região com produtos tropicais. O trigo e o vinho eram trazidos do Chile. Os animais, tanto de carga quanto para o abastecimento de carne, procediam da planície platina. Alguns produtos têxteis vinham da cidade de Quito.

Prodanov (2002) salienta que o poder de compra da elite de Potosi também chegava a mercados internacionais, de onde compravam tecidos de Granada, Flandes e da Calábria, chapéus de Paris e de Londres, jóias da Índia, do Ceilão, do Panamá, cristais venezianos, tapetes persas e outros produtos de muito valor.

Potosi se torna o polo aglutinador de uma economia agrária periférica, que se estende por uma enorme área, constituída apenas para abastecê-la, 
pois na lógica sistêmica do Antigo Sistema Colonial, o lucro oriundo das atividades de mineração compensava tais investimentos.

Como observa Prodanov (2002), Potosi também foi responsável pelo surgimento da segunda cidade mais importante do Vice-Reino, entre os séculos XVI e XVIII. Trata-se da atual cidade de Sucre, que foi fundada sobre um povoado indígena chamado Charcas, em 1538, com o nome de La Plata. Este local, que antes da denominação atual chamava-se Chuquisaca, dista cerca de 120 quilômetros de Potosi e foi o lugar escolhido pela elite potosina tanto para fugir dos rigores naturais de Potosi quanto para articular os processos inerentes à exploração da prata. Seu acelerado crescimento se deu por sua posição geográfica estratégica, pois se tornou confluência de caminhos dentro do Vice-Reino.

No que tange ao escoamento das mercadorias e ao recebimento dos produtos necessários à manutenção das condições básicas de vida na área mineira, Moraes nos mostra que

A ocupação do território colonial estrutura-se num padrão voltado para fora, isto é, a apropriação dos espaços obedece a um itinerário que exprime o sentido prioritário dos fluxos (centrípetos do ponto de vista da colônia, e centrífugos na ótica da metrópole) $\mathrm{O}$ desenho espacial básico observado é o denominado 'bacia de drenagem', em que um eixo de circulação central ramifica-se por caminhos que vão buscar as zonas de produção, e esse eixo tem por destino um porto (lacustre, marinho ou estuarino) que articula os lugares drenados com os fluxos do comércio ultramarino... Quanto mais ampla a área de drenagem e quanto mais intenso o fluxo praticado, maior será a importância do porto de referência na hierarquização dos lugares coloniais no interior de cada império. (MORAES, 2005, p. 68)

A exportação dos minerais extraídos nesta área colonial, segundo Moraes (2000), em sua maior parte saía de Potosi e era enviada para Lima, de onde seguia para o porto de Callao (Mapa 3), seguindo para o Panamá e de lá, 
enviada para Havana, de onde seguia para Sevilha, na Espanha. Tal trajeto, de acordo com Moraes, durava cerca de dezoito meses.

Sevilha, situada a cerca de 110 quilômetros do litoral, não era uma cidade marítima, apesar de ter sido o principal porto espanhol, pois, de acordo com Macleod (2008), possuía algumas vantagens: estava protegida tanto das tempestades atlânticas quanto dos ataques de piratas.

Macleod (2008) escreve que pelo porto de Buenos Aires escoava-se grande parte da prata contrabandeada de Potosi, via Salta, Tucumán e Córdoba que, repassada para contrabandistas da Colônia do Sacramento e do Rio de Janeiro (Mapa 3), seguia para Lisboa e para as possessões portuguesas na Ásia, a fim de financiar a penetração lusa nesse ponto do planeta.

Aliás, vale ressaltar que esse comércio clandestino de prata foi responsável pela segunda fundação da cidade de Buenos Aires, em 1580. Esta cidade tornou-se não só uma das principais rotas de abastecimento de Potosi, principalmente de cavalos, mulas, gado bovino, mas também de manufaturas europeias e artigos de luxo, criando uma ligação entre a região mineira e o oceano Atlântico, trajeto bem mais curto que a rota legal via Panamá, Callao e Lima. Tal circuito foi legalizado, em 1595, pela coroa espanhola.

Não é à toa que na primeira metade do século XVII, os portugueses pretendiam, conforme afirma Bandeira (1985), tomar posse de Buenos Aires, pois além de permitir o controle da Bacia do Prata, abriria caminho para as minas de Potosi. Tal pretensão, porém não se concretizou. Reabrir a rota clandestina entre o Atlântico e Potosi também não foi levada adiante. Restou então à metrópole portuguesa fundar, em 1680, a "Colônia do Sacramento na margem oeste do rio da Prata, para convertê-la em depósito do comércio de contrabando com Buenos Aires, que se tornava então um dos principais portos da América espanhola." (MAURO, 2008, p. 472). 


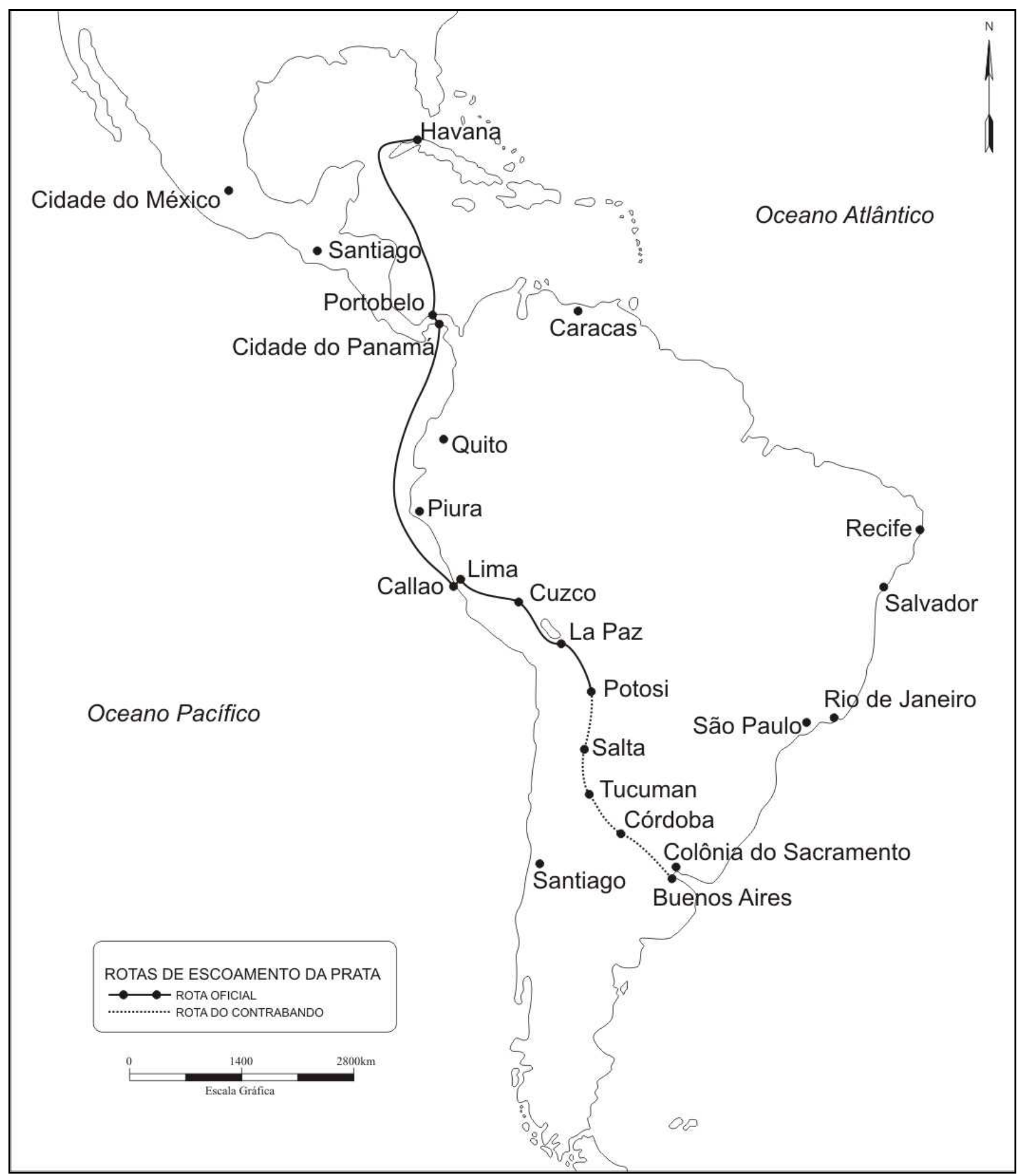

Mapa 3

Rotas de escoamento da prata (MACLEOD, 2008, v. II, p. 257 - adaptado) 
O declínio econômico de Potosi, quando a produção de prata entrou numa espiral descendente, teve início no ano de 1592 e estendeu-se até a segunda metade do século XVII. Além da exaustão natural das minas, outro fator bastante importante para sua retração foi o esgotamento da produção de mercúrio das minas de Huancavelica no Peru e de Almadén na Espanha. Potosi, que chegou a ter uma população fixa, no início do século XVII, de aproximadamente 160 mil habitantes, viu esse número cair para não mais que 30 mil. Na época da independência boliviana, em 1825, apenas nove mil pessoas viviam em Potosi.

Outro processo distinto de ocupação do altiplano se deu pelo chamado "Piemonte" andino. A cidade de Assunção, fundada em 1537, serviu tanto como ponto de partida para expedições quanto de centro abastecedor de mate, milho e batata-doce para Potosi. A partir de Assunção, os espanhóis, em sentido noroeste, fundam em 1561 a cidade de Santa Cruz de la Sierra, que começa a fornecer produtos tropicais à zona mineradora.

Esses dois processos distintos de ocupação, sendo o primeiro a partir do atual Peru e o segundo a partir do atual Paraguai, que possibilitaram a criação de novos assentamentos populacionais em áreas de difíceis condições de vida, mostra-nos o grandioso circuito armado pela metrópole para garantir a extração, circulação e exportação da prata, envolvendo um arco maior de espacialização. Este reunia as áreas andina e platina num território constituído pelo poder das relações sociais referentes ao Antigo Sistema Colonial, "numa lógica na qual cada colônia aparece como parte de uma estrutura que trabalha para o centro do sistema" (MORAES, 2005, p. 64), sendo que nesse processo "as colônias são porções da economia-mundo, na qual se apresentam como partes subordinadas de um império, e, em conjunto, delimitam a verdadeira periferia do mundo capitalista". (ibidem, p. 56)

Os portugueses, nas palavras de Bandeira (1985), ficaram frustrados ao descobrir que nas terras destinadas pelo Tratado de Tordesilhas não encontraram um mísero grama de prata.

Os metais, que a imaginação escaldante dos primeiros exploradores pensava encontrar em qualquer território novo, 
esperança reforçada pelas prematuras descobertas castelhanas, não se revelaram tão disseminados como se esperava. (PRADO JUNIOR, 1994, p. 25)

Para tal intento, os bandeirantes começaram a embrenhar-se pelo interior do continente para encontrar o Eldorado ou mesmo alcançar Potosi. Conforme Miranda (2007), em 1621, uma expedição chefiada por Antônio Castanho da Silva partiu de São Paulo e, via Cuiabá, chegou a Potosi. Porém, não logrou êxito em sua expedição, pois morreu logo em seguida, em decorrência das adversidades que o trajeto lhe impôs.

Tanto Moraes (2000) quanto Ferreira (2005) relatam a realização de uma expedição oficial, em nome do rei Dom João IV, do bandeirante Antônio Raposo Tavares, ocorrida entre 1648 e 1651, que tinha como objetivo, além de descobrir pedras preciosas, o de reconhecer e ampliar os domínios portugueses na América.

Essa expedição dividiu-se em duas tropas, uma delas, chefiada pelo próprio Antônio Raposo Tavares e outra, por Ântonio Pereira de Azevedo, ambas chegando à região dos índios Serranos, na região de Potosi. Posteriormente, navegaram pelo rio Guapaí até o rio Mamoré e deste, para o rio Madeira. Daí enfrentou o rio Amazonas, chegando à cidade paraense de Gurupá, em 1651. Finalmente alcançaram Belém, no estado do Pará, de onde os 59 brancos sobreviventes retornaram para São Paulo. Com esse trajeto de mais de dez mil quilômetros, a Bandeira de Antônio Raposo Tavares fez uma descoberta importante. No relato de Moraes,

Partindo de São Paulo, sua expedição atingiu o sopé andino, transitando nas imediações de Santa Cruz de la Sierra, em seguida atravessando o interflúvio dos Parecis, penetrou na região amazônica, atingindo Belém, pela rota dos rios Mamoré, Madeira e Amazonas. Tal itinerário deu ciência da proximidade (e da não comunicação) das duas grandes bacias hidrográficas sul-americanas, pondo por terra o mito cartográfico da ilha Brasil. (MORAES, 2000, p. 395) 
A importância dessa Bandeira reside na contribuição à configuração territorial do Brasil, pois quando da assinatura do Tratado de Paz e Amizade entre portugueses e espanhóis, em 1668, as terras baixas do oeste amazônico foram reconhecidas como território português, utilizando para tal reconhecimento o princípio do uti possidetis ${ }^{8}$. Dessa maneira, Raposo Tavares, "incorporava à zona de influência política da Coroa Portuguesa, toda a região do Oeste. E nela, todo o trecho encachoeirado do rio Madeira." (FERREIRA, 2005, p. 24)

A particularização do Antigo Sistema Colonial, nas condições específicas do altiplano, engendrou um modo de sociabilidade marcado pela imposição da visão de mundo eurocêntrica e a consequente subalternização das populações indígenas, relegadas à mera condição de mão-de-obra necessária à viabilização da economia colonial. Moraes (2000) destaca que a mineração implicou construções, assentamento, redes de abastecimento, perenização de fluxos, além de melhor organização da estrutura administrativa, ou seja, a incorporação exploratória do novo espaço, das terras e pessoas, à dinâmica da economia metropolitana.

Nesta perspectiva, as hierarquias sócio-culturais tornam-se extremamente rígidas, expressando o caráter colonial desta sociedade, na qual o branco/europeu associa-se às várias nuances do colonizador e/ou agente metropolitano e o indígena ao fardo laboral nas atividades mineradoras, cabendo aos mestiços transitar nos interstícios desta hierarquia social, simultaneamente, estrutura de produção. Como aponta Aníbal Quijano "Na América, a ideia de raça foi um modo de outorgar legitimidade às relações de dominação impostas pela conquista." (QUIJANO, 2005, p. 228)

Portanto, não havia uma comunidade possível, real ou imaginada, nas condições vigentes de inferiorização da massa de população indígena e mestiça, uma vez que a identidade nacional, como diz Moraes (2009) é uma construção cultural de múltiplos caminhos de afirmação. Sendo assim, as elites que se constituíam a partir das relações econômicas coloniais não se preocupavam em criar elementos de consentimento e/ou persuasão para se associar ao caráter coercitivo do exercício do seu poder. "Os espanhóis, além

\footnotetext{
${ }^{8}$ Cada um dos lados mantém o que ocupou, ou seja, a terra é do país que a ocupa.
} 
de ocupar a paisagem física, também se apropriaram da paisagem espiritual e cultural." (THIESSEN-REILY, 2008, p. 360)

O exercício do poder, segundo os moldes da hegemonia gramsciana, pressupõe a integração mínima do povo ao sistema vigente, contrariando a situação concreta de visão e ação instrumental do povo, visto apenas como força de trabalho por parte da elite europeizante. A grande população indígena, a maior parte analfabeta no idioma metropolitano, permaneceu fora do processo de construção nacional das elites.

Contudo, enquanto contradição do próprio processo de particularização do Antigo Sistema Colonial, ocorreu a preservação das comunidades indígenas, que foram recontextualizadas enquanto elemento de apoio sistêmico, já que faziam a gestão (controle e reprodução) da mão-de-obra. Instituições tradicionais, como a mita (trabalho compulsório nas minas) e a pongaje (o trabalho índio empregado para o serviço pessoal), foram apropriadas pelos espanhóis e pela elite criolla, em função da enorme necessidade de mão-de-obra para a mineração, só sendo abolidas oficialmente em 1812. Na leitura de Urquidi "as comunidades indígenas permaneceram como residindo num país diferente, ocupando o mesmo território com as oligarquias, mas de modo subterrâneo". (URQUIDI, 2007, p. 74)

Se por um lado essas comunidades representavam a submissão à ordem colonial, também se constituíram em polos de aglutinação da população indígena e de sua cultura. Essa ambiguidade gerou movimentos de resistência nas áreas do Vice-Reinado do Peru, em fins do século XVIII, como as revoltas de Tupac Amaru e Tupac Katari, conforme Gerab e Resende (1987).

Esses movimentos de rebeldia das populações coloniais foram debelados a ferro e fogo pelo consórcio formado pela elite colonial e as autoridades metropolitanas. A Era das Revoluções - a crise do Antigo Regime e do Antigo Sistema Colonial - na América hispânica não assistiu à constituição de nações e nacionalismos, no sentido proposto por Eric Hobsbawm em seu livro "Nações e Nacionalismos desde 1780", de 2004.

A tônica das Luzes na América espanhola foi o protesto anticolonial, que galvanizou as elites no sentido de romper com a metrópole e se apropriar do poder colonial, como fundamento para a construção de seu Estado.

Mariátegui indica que: 
As idéias da Revolução Francesa e da constituição estadunidense encontraram um clima favorável para sua difusão na América do Sul, porque na América do Sul já existia, ainda que embrionariamente, uma burguesia que, diante de suas necessidades e interesses econômicos, podia e devia ser contagiada pelo humor revolucionário da burguesia européia. (MARIÁTEGUI, 2008, p. 36)

Os movimentos de independência na América Latina não foram comandados pela massa indígena. Os líderes foram os chamados "Crioulos" (descendentes de espanhóis nascidos na América), que não pensavam em criar uma sociedade indígena e igualitária. Suas pretensões eram apenas se apossar das riquezas do território que haviam sido apropriadas pelos espanhóis. Mas, como tomar o poder sem perder o controle da grande massa indígena? A saída encontrada foi a adoção do nativismo que, segundo Chasteen,

glorificava a idéia de uma identidade americana definida pelo local de nascimento, algo que os crioulos compartilhavam com os povos indígenas, com aqueles de sangue misto, mesmo com os filhos de escravos africanos. Com os apelos nativistas, os crioulos poderiam conquistar a independência mantendo a hierarquia social mais ou menos intacta... A maioria dos crioulos conservou as velhas noções da supremacia branca, como nos recém-independentes Estados Unidos. (CHASTEEN, 2001, pp 88-89)

Portanto, os processos de independência na Iberoamérica, não cancelou o colonialismo nas nações latino-americanas. Pelo contrário, tornou-as pós-coloniais: agora se autogovernando, mas ainda moldadas pela herança colonial. (ibidem, p. 93) 
De acordo com Roberto Choque, o processo de independência na Bolívia, comandado pela elite criolla, tratou primeiro de assegurar a independência da Espanha para, num segundo momento, se preocupar com os índios, a maioria da população. Em suas palavras:

A independência criolla do Estado ou da coroa da Espanha não
significou sua libertação (dos indígenas) do sistema de
exploração colonial, ou seja, com o novo Estado Republicano
continuaram todas as suas cargas tributárias e serviços
pessoais. Em outra ordem de coisas, o novo Estado
marginalizou o indígena da sociedade civil. (CHOQUE, 2006, p. 16)

Cabe ressaltar que os processos de independência na América Latina tiveram a participação inequívoca da Inglaterra, berço do capitalismo liberal, reconhecendo e financiando as repúblicas nascentes que imediatamente passaram a desempenhar seu papel na clássica Divisão Internacional do Trabalho, como fornecedores de produtos primários e receptores de produtos manufaturados.

No campo das ideias, a elite criolla e mesmo Simon Bolívar se enxergavam como continuadores de uma civilização europeia na América, uma vez que, no imaginário europeu que influenciava essa elite, "as Américas eram consideradas, da perspectiva europeia colonial, como uma extensão e não como algo diverso dela". (MIGNOLO, 2003, p. 182)

\subsection{O SURGIMENTO DO ESTADO BOLIVIANO}

O altiplano meso-sul-americano, também conhecido como Alto Peru ou Audiência de Charcas, estava nitidamente vinculado ao padrão societário andino (combinação de estruturas incaicas e europeias hegemonizadas pelo poder metropolitano). A região contituía-se em uma zona de contato entre o Vice-Reinado do Peru (com sede em Lima, formado em 1543) e o ViceReinado do Prata (com sede em Buenos Aires, organizado em 1776), ao qual 
se vinculou, a partir dessa data, à Audiência de Charcas, por imposição da coroa espanhola. A consequência imediata da transferência foi o declínio econômico de Lima. Segundo Brading,

O resultado foi uma mudança radical no equilíbrio geopolítico do continente. Pois, com seu monopólio comercial já rompido pela abertura da rota comercial através do Cabo Horn, Lima, a antiga capital de todo o império na América do Sul, sofreu uma grande perda de prestígio. A inclusão do Alto Peru no novo vice-reino, com o propósito de fornecer a Buenos Aires os lucros fiscais de Potosi, preparou o caminho para a divisão política permanente da zona andina. (BRADING, 2008, p. 405)

Mercado (1988) escreve que o nascimento da Bolívia, como país independente, é resultado de dois fatores. O primeiro nos remete à crise do azougue (mercúrio), resultado do bloqueio de Napoleão Bonaparte às Ilhas Britânicas que acabou por arruinar a já combalida economia de Potosi, que se encontrava numa grande depressão; o segundo, remete-nos à guerra das republiquetas ${ }^{9}$. Alguns antecedentes, porém, devem ser destacados.

Waddell (2009) expõe que no início do século XIX Napoleão Bonaparte invade a Espanha e derruba a realeza espanhola, fazendo seu irmão José Bonaparte chegar ao trono daquele país, controlando, dessa forma, o poder. A usurpação do trono espanhol não foi bem recebida pelas elites sul-americanas, que declararam lealdade a Fernando VII.

Nesse contexto, as elites criollas vislumbraram a possibilidade de assumirem definitivamente o poder para romper com uma metrópole sob domínio francês. Porém, o governo patriótico espanhol, situado em Cádiz, no sul da Espanha, insistia em manter seu monopólio sobre suas colônias. Por outro lado, a Inglaterra, apesar de apoiar o governo espanhol, insistia na liberalização comercial das colônias espanholas, obviamente, para benefício próprio. Tal posicionamento tornou tensas as relações entre o governo patriótico espanhol e o governo imperial inglês, dificultando, inclusive, uma maior participação inglesa no comércio colonial.

\footnotetext{
${ }^{9}$ Grupos independentistas guerrilheiros armados.
} 
No caso da América Espanhola, porém, as circunstâncias europeias ditavam que nem a França e nem a Espanha eram capazes de estabelecer o controle, ao passo que, no entender da Inglaterra e dos Estados Unidos, seus interesses estavam em evitar qualquer ação decisiva. Assim, as colônias espanholas tiveram oportunidade de determinar seu próprio futuro. (WADDELL, 2009, p. 239)

Fernando VII foi reconduzido ao trono espanhol em 1814, reduziu as conquistas liberais e, para restaurar a dominação colonial, enviou tropas à América espanhola para sufocar os movimentos independentistas. Por intermédio de um acordo assinado com a Inglaterra no mesmo ano, este país se comprometia a não enviar armas e munições diretamente para os insurgentes na América. No entanto, a Inglaterra exportava tais equipamentos por portos neutros para chegarem à América. Além disso, o governo imperial espanhol ofereceu ao Império britânico o monopólio do comércio com as colônias americanas, em troca de a Inglaterra desestimular as aspirações rebeldes.

Como o governo imperial inglês entendia que o processo revolucionário só seria contido com a concessão de algumas exigências aos coloniais, não aceitou a proposta. Essa atitude produziu um efeito contrário, pois aumentou ainda mais o ânimo das lutas pela independência na América espanhola, ainda mais com a proclamação, em 1823, da chamada "Doutrina Monroe" pelo congresso estadunidense, que declarava que qualquer interferência europeia em terras americanas seria considerada uma atitude não amistosa aos Estados Unidos.

O Alto Peru (Charcas) foi palco do primeiro movimento independentista da América espanhola. Conforme Klein (2004), em 1809, rebeldes liderados por Pedro Domingo Murillo instauraram uma Junta Tuitiva e proclamaram um regime independente e autônomo em nome de Fernando VII, rei da Espanha. Esse movimento foi sufocado por uma tropa comandada pelo presidente de Cuzco, o senhor José Manuel de Goyeneche, que estava comprometido com a junta central espanhola, e terminou com a morte de Murillo, em outubro de 1810. 
Bushnell (2009) salienta que os argentinos, num primeiro momento, interessados nos frutos que o comércio da prata de Potosi poderia continuar a render à Buenos Aires, já que mantiveram o monopólio sobre o comércio exterior do Rio da Prata, com o apoio da população de Cochabamba, enviaram, em 1810, uma coluna militar até o Alto Peru, chefiada por Juan José Castelli, que chegou a ganhar batalhas em Potosi, Chuquisaca e La Paz.

em sete de novembro de 1810, o exército revolucionário obteve uma vitória decisiva na batalha de Suipacha e logo após entrava em Potosi. Em diversos outros lugares, inclusive em Chuquisaca e em La Paz, os patriotas locais tomaram o poder e rapidamente estabeleceram relações com os invasores. (BUSHNELL, 2009, p. 149)

Mais uma vez as tropas legalistas de José Manuel de Goyeneche partiram para estancar o movimento e, em 20 de julho de 1811, na localidade de Huaqui, próxima ao lago Titicaca, derrotou a tropa argentina, perseguindo-a até as proximidades de Tucumán.

Nova marcha argentina com destino ao altiplano ocorreu em 1813, desta vez comandada por Manuel Belgrano. Ele e seus homens conseguiram chegar a Potosi, mas foram derrotados no final de 1813, devido a superioridade militar das tropas legalistas comandadas, desta vez, pelo general espanhol Joaquín de la Pezuela, que derrotou outro exército argentino em 1815. Uma nova investida argentina ocorreu em 1817, também sem sucesso.

Depois dessas derrotas, os argentinos se retiraram do combate direto pela emancipação do Alto Peru, deixando a tarefa da libertação para grupos armados denominados republiquetas. Estes se constituíram como movimentos armados de libertação nacional, entre 1809 e 1824, até a chegada, em 1825, de um exército libertador vindo do Peru, comandado por Antonio José de Sucre e por Simon Bolívar.

Conforme Mercado (1988), o Alto Peru independente da Espanha, apesar de ser, antes dos conflitos pela independência, parte do Vice-Reinado do Prata, não iria fazer parte das Províncias Unidas do rio da Prata. Os argentinos, praticamente, abandonaram o Alto Peru nas mãos das 
republiquetas, pois a decadência econômica de Potosi e a violência da guerra fizeram que os governantes portenhos não cobiçassem a região.

O representante de Buenos Aires, Carlos María de Alvear, ficou encarregado de negociar com Simon Bolívar a não participação do Alto Peru nas Províncias Unidas do rio da Prata. Portanto, o caminho natural seria a união com o Peru, mas o sentimento dominante da elite criolla do Alto Peru era o de uma república separada para não ficar à mercê da elite limenha, acreditando em um novo resplandecer de Potosi.

Nesse sentido, a Bolívia nasce como um "Estado-tampão" entre a Argentina e o Peru. Além disso, a elite da cidade de Lima tinha na construção do Estado boliviano um anteparo para a agressividade argentina. Por isso, Simon Bolívar não conseguiu levar a cabo suas pretensões de construir a "Confederação Andina", que seria formada pelo Peru, Alto Peru e pela GrãColômbia $^{10}$. Além do mais, segundo Klein (2004), a Argentina tinha uma posição hostil à ideia e o próprio Simon Bolívar temia um Estado peruano com muito poder.

A independência do Alto Peru se concretizou em 6 de agosto de 1825, quando, sob a liderança do general Antonio José de Sucre e um grupo de 48 delegados se reuniram em Chuquisaca e ali constituíram uma nação independente, com 2.363.769 $\mathrm{km}^{2}$, batizada cinco dias depois com o nome de Bolívia (Mapa 4).

\footnotetext{
${ }^{10}$ composta pelos atuais territórios do Panamá, Colômbia, Venezuela e Equador.
} 


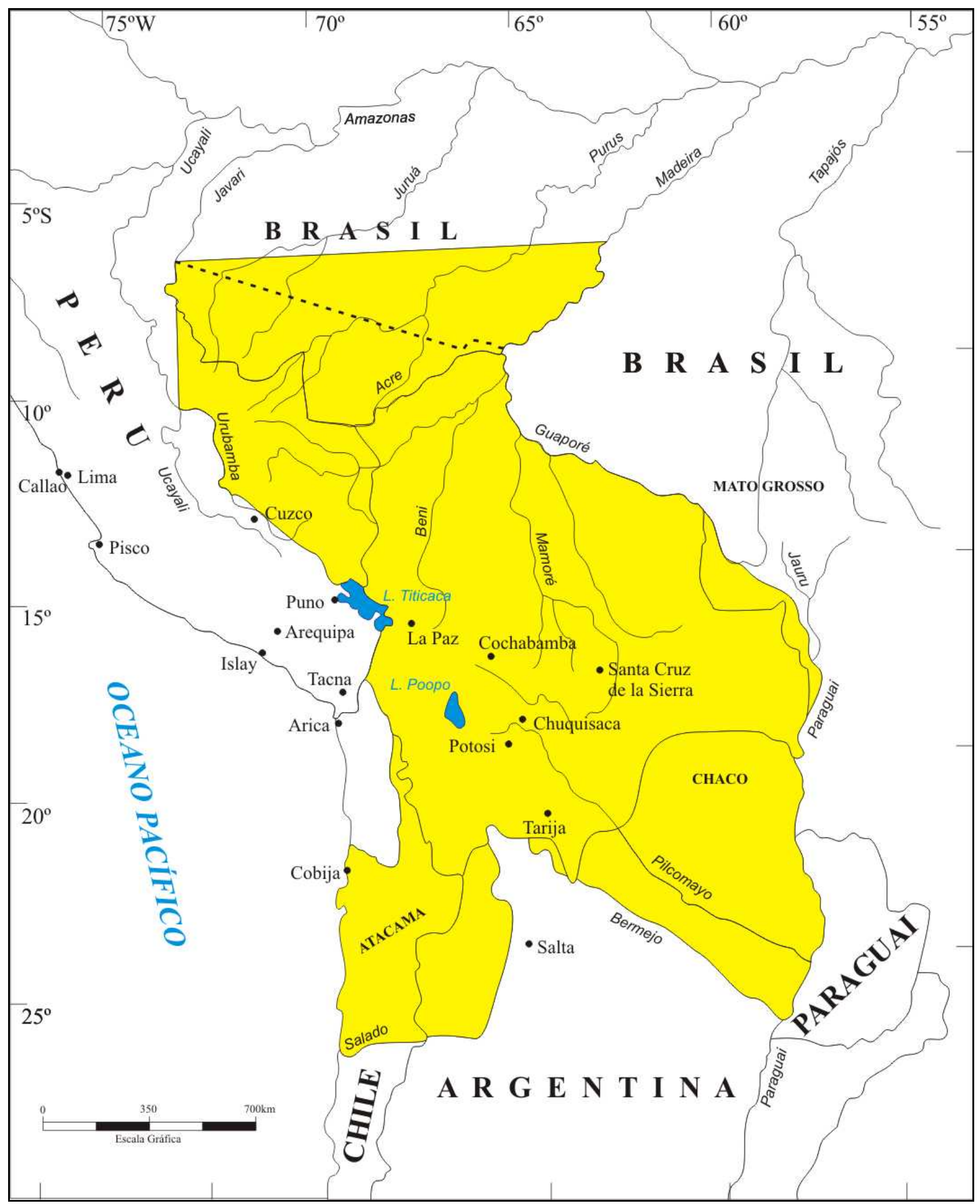

Mapa 4

Território original da República da Bolívia em 1825 (KLEIN, 1991, p. 72 - adaptado) 
Surgiu como "um Estado fraco e isolado do mundo... um Estado em guerra perpétua com sua própria população" (MERCADO, 1988, p. 19). Na caracterização de Vallaux (1914), é um Estado simples, com uma pequena coesão interna em suas redes de transportes. Uma república que nasce e ganha como herança uma economia estagnada.

Uma república eminentemente indígena, que "tinha uma população estimada de 200.000 brancos, 100.000 chollos e, aproximadamente, 800.000 camponeses índios" (KLEIN, 2004, p. 73), cuja primeira constituição foi escrita por Simon Bolívar, que emprestou o seu nome ao novo país, e baseava-se nas constituições napoleônicas. Como a mesma carta magna também foi adotada no Peru, alimentou-se, dessa forma, a esperança de uma união entre os dois países que, no entanto, teve curta duração.

Sucre, o primeiro presidente da jovem república abandona o poder em 1829, sendo substituído por Andrés de Santa Cruz.

Para se compreender a construção da identidade nacional boliviana é necessário entender as raízes e as consequências das guerras travadas pela Bolívia. Segundo Wasserman:

As classes dominantes usaram as derrotas como pretexto para justificar a ideia de que a heterogeneidade étnica do país constituía-se em uma 'fraqueza originária', um 'defeito congênito', que impedia a Bolívia de ganhar uma guerra contra vizinhos poderosos e que, ao mesmo tempo, constituir-se-ia em um obstáculo para se atingir a modernidade. (WASSERMAN, 2004, p. 320)

O Estado boliviano, mesmo nascendo "fraco", foi alvo da cobiça externa devido à riqueza mineral contida nas entranhas do seu território. Além disso, o nascente Estado encontrava-se numa posição geográfica privilegiada entre a bacia hidrográfica do Prata, que Ihe proporciona uma ligação com o Atlântico sul; a bacia hidrográfica Amazônica, por meio do qual podia atingir o oceano Atlântico, via Belém do Pará e, a partir daí, os mercados da costa leste estadunidense e o europeu; e a saída para o oceano Pacífico, pelo porto de Cobija, via deserto do Atacama. 
Esse Estado foi, ao longo de sua existência, sendo fragmentado, constituindo, nas palavras de Urquidi "mais uma prova do descaso com que as elites incorporaram o território nacional. Para a oligarquia, o território nacional, até as primeiras décadas do século $\mathrm{XX}$, não era questão fundamental". (URQUIDI, 2007, p. 73) 
CAPÍTULO 2

\section{A GUERRA DA CONFEDERAÇÃO PERU-BOLIVIANA}

A primeira derrota boliviana deu-se na chamada Guerra da Confederação Peru-Boliviana (1836-1839).

Bonilla (2009) escreve que a Bolívia, mesmo com sua independência em 1825 e apesar de possuir em seu pequeno litoral voltado para o oceano Pacífico, um porto franco na localidade de Cobija, o acesso ao mesmo era bastante penoso, devido a descida da íngreme escarpa andina, além da difícil travessia do deserto de Atacama, no lombo de mulas. Mesmo no seu auge, o porto do Cobija movimentava apenas um terço do comércio exterior da Bolívia, abastecendo, principalmente, o sul boliviano.

O acesso mais usado pelos bolivianos para o oceano Pacífico ainda continuava a ser realizado pelo Peru, em função da ausência quase absoluta de uma rede de transportes internos no território boliviano. $\mathrm{O}$ abastecimento do norte da Bolívia se dava ora navegando, ora contornando o lago Titicaca até a localidade de Puno. Daí se atingia o porto de Molendo ou o de Arica, no Peru (Mapa 5).

Nas palavras de Ferreira:

Daí desciam as vertentes dos Andes até aos portos de mar de Molendo, Arica, Pisagua e Iquique. Nascia, pois, a Bolívia em condições dramáticas: sem porto de mar, sendo obrigada agora a servir-se dos portos de um país estrangeiro, o Peru. Não obstante o território boliviano chegasse até o mar, tornavase difícil ao jovem país construir um caminho próprio até o porto que construísse, no litoral. Essa dificuldade era conseqüência da própria geografia física da Bolívia [...] A faixa litorânea era uma planície deserta, que terminava onde começam as faldas da cordilheira dos Andes. [...] era pois, este, o relevo do território boliviano: um altiplano entre duas cordilheiras." (FERREIRA, 2005, p. 55) 


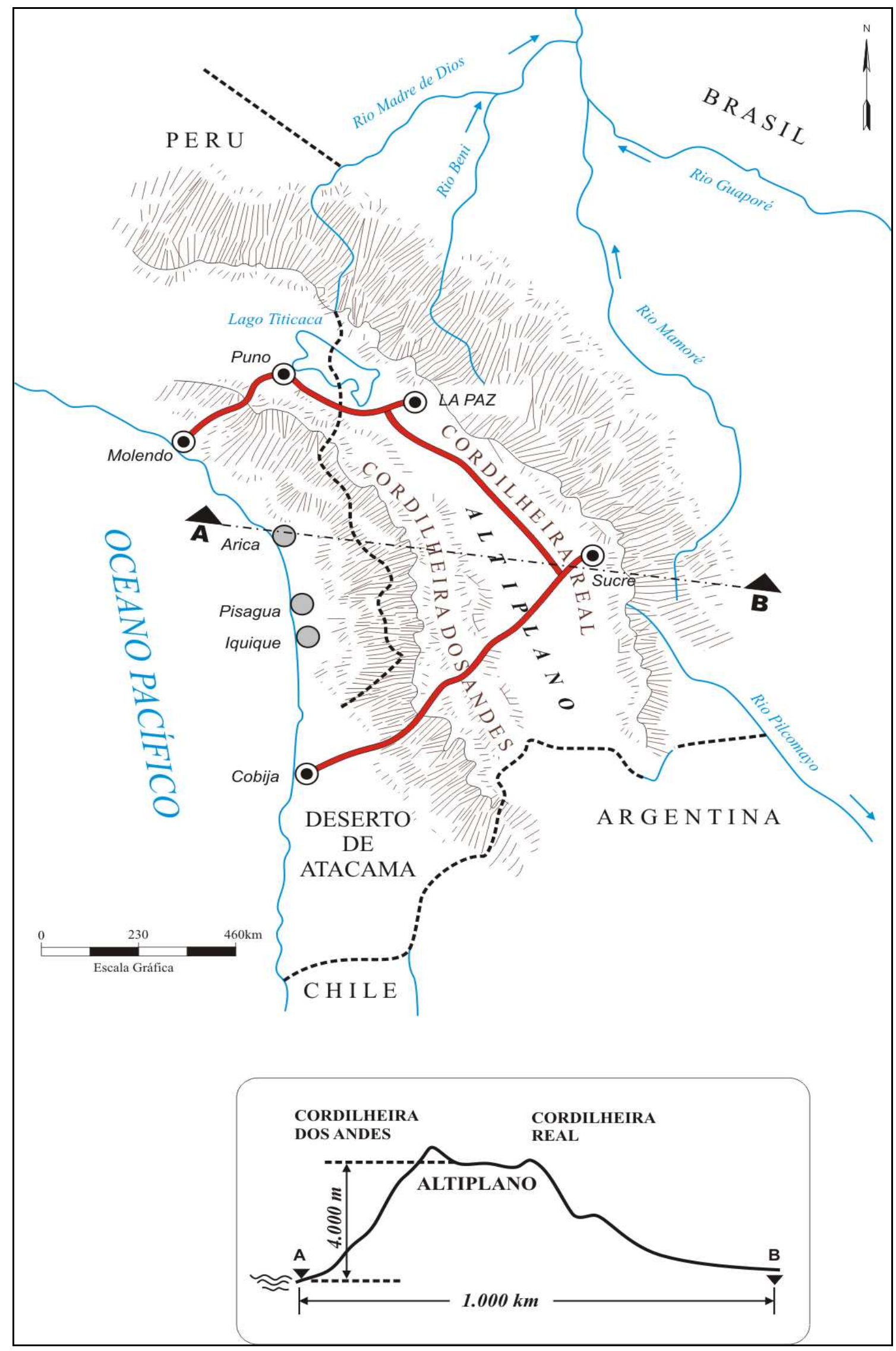

Mapa 5

Acessos da Bolívia para o oceano Pacífico em 1825 (FERREIRA, 2005, p. 57 - adaptado) 
Percebe-se, dessa forma, a necessidade da unificação entre as jovens repúblicas do Peru e da Bolívia, principalmente por parte desta, em função da quase inexistência, naquele momento, de técnicas apropriadas para vencer os desafios naturais impostos pela severidade da vertente oeste da Cordilheira dos Andes. Nas palavras do próprio Santa Cruz, "era uma questão de vida ou morte para a Bolívia" (BONILLA, 2009, p. 575) a utilização dos portos peruanos de Molendo e, principalmente, de Arica.

Quando Peru e Bolívia se unificaram, por um decreto assinado em 28 de outubro de 1836, sob o comando de Andrés de Santa Cruz em aliança com alguns caudilhos do sul do Peru descontentes com o governo limenho, o novo mandatário da recém-fundada Confederação Peru-Boliviana começou a oferecer, segundo Bonilla (2009), recompensas para os navios que viajassem diretamente para o porto de Callao, na costa peruana, desistindo da escala no porto chileno de Valparaíso. Este era o principal elo estratégico no comércio entre a Inglaterra e o Peru, efetivando-se, principalmente, via estreito de Magalhães, além de tornar livres os portos de Arica, Cobija, Callao e Paita. Tal benefício consistia numa estratégia para tentar capitalizar para o novo Estado o enorme movimento existente no porto chileno.

O governo chileno não aceitou a unificação entre os dois países e muito menos a tentativa de diminuir a importância do porto de Valparaíso, declarando guerra à nascente Confederação em 26 de dezembro de 1836. O Chile contava, em suas fileiras, com diversos exilados, tanto peruanos quanto bolivianos e alegava que a união entre Bolívia e Peru ameaçava a independência das demais nações americanas.

Segundo Santos:

O Peru constituía-se, desde o período colonial, no principal mercado para a produção de trigo e farinhas chilenas. Nesse momento, o Chile, que já havia conseguido superar a fase de tensões centrífugas internas com o início da chamada fase dos 'Governos dos Decênios', lançava-se no projeto de transformar Valparaíso no principal porto do Pacífico Sul, ponto de parada obrigatório dos navios que dobravam o Cabo de Hornos com 
destino ao Oriente. A hegemonia de Valparaíso sobre Callao foi decidida na guerra que o Chile sustentou contra a Confederação Bolívia-Peru, que teve como causa imediata a denúncia do tratado que concedia preferências comerciais mútuas e a recusa das autoridades da confederação a derrogar a legislação que aumentava os direitos peruanos sobre as mercadorias que chegassem ao seu mercado com escala em Valparaíso. Porém, o motivo primordial do conflito bélico foi dirimir a supremacia comercial do Pacífico Sul entre Valparaíso e Callao. (SANTOS, 2002, p. 51)

A análise de Santos (2002) vai ao encontro do que escreveu Bruit "O fundador da República (chilena), Diego Portales, ao justificar a necessidade de destruir a Confederação Peru-Boliviana assinalava, entre outras razões, a do domínio que a nova organização trataria de exercer no Pacífico, arrebatando-o de nós" (BRUIT, 1985, p. 99), ou seja, a possibilidade de a Confederação alcançar a hegemonia nas águas do Pacífico oriental era uma grande preocupação do governo chileno. Além disso, Diego Portales afirmava que Bolívia e Peru juntos, seriam sem sombra de dúvida, um país muito superior ao Chile e que este não sobreviveria a tal união.

Bonilla (2009) escreve que a confederação não encontrou resistência apenas por parte do Chile. Internamente, as elites, tanto de Lima quando de La Paz, se opuseram à unificação. Em Lima, a elite se opôs ferozmente à divisão do país, quando o sul do Estado peruano tornou-se um estado separado dentro da confederação, pois Santa Cruz queria constituir três estados dentro da Federação: Peru do Norte, Peru do Sul e Bolívia. Em La Paz, o descontentamento acontecia pelo fato de Andrés de Santa Cruz ter escolhido a cidade de Lima para a capital da Confederação Peru-Boliviana.

Rosas, o ditador argentino, também não concordou com o nascimento da Confederação e, ao alegar uma disputa de fronteiras, declarou guerra a ela em maio de 1837, enviando tropas para combater a Confederação. No mesmo ano, essas foram derrotadas por Santa Cruz. 
Ao término da guerra, em janeiro de 1839, com a vitória chilena na batalha Yungay, norte do Peru, a Confederação foi encerrada e Santa Cruz exilado, primeiramente em Guayaquil e, posteriormente, na Europa.

Dessa forma, manteve-se a hegemonia do Pacífico Sul nas mãos do Chile.

Para Mercado, a intenção de Andrés, apesar do projeto conservador, pretendia "dar um projeto nacional a um país que não o tinha. Há nisto a tentativa de aplicação do centralismo de províncias, que tinham deixado de ser centrais." (MERCADO, 1988, p. 20)

Não é sem razão que durante a existência da Confederação PeruBoliviana, esta foi regida por uma constituição promulgada por Andrés de Santa Cruz, baseada na primeira constituição do Peru e da Bolívia, escrita por Simon Bolívar. O intento seria criar uma república oligárquica com um verdadeiro sentido dos interesses nacionais.

Vale salientar que, com o término da Confederação Peru-Boliviana, o novo presidente peruano, o general Agustín Gamarra, comandou uma invasão ao território boliviano, na tentativa de impor a hegemonia peruana sobre a Bolívia. O general foi derrotado e morto em Ingavi, norte da Bolívia, em novembro de 1841, por tropas do exército boliviano.

\section{A PERDA TERRITORIAL PARA O PERU}

A Bolívia perdeu para o Peru aproximadamente $220.000 \mathrm{~km}^{2}$ de seu território amazônico. Tal discussão ficou eternizada com o livro Peru x Bolívia, escrito por Euclides da Cunha. Uma tentativa de acordo aconteceu em 1897, porém, sem sucesso entre as partes litigantes.

Conforme consta nos relatos de Tocantins, a área disputada pelos dois países era bastante extensa.

O ministro Hérnan Velarde dizia que o Peru reclamava da Bolívia todo o território compreendido entre a nascente do Javari e a confluência do Beni - a totalidade do atual território do Acre - área incluída na zona litigiosa e sujeita a arbitragem 
do Tratado Peru-Bolívia, de 30 de dezembro de 1902. (TOCANTINS, 1979, vol. 2, pp. 353-354)

Esse território em disputa é uma área de difícil acesso e o mapeamento fronteiriço entre os dois países era de complexa solução, pois suas fronteiras se imbricavam desde os tempos das Audiências e até mesmo com a constituição da Confederação Peru-Boliviana.

Com o avanço das disputas pelo território do Acre, a disputa entre Peru e Bolívia se acirrou.

Tocantins (1979) escreve que como os países não chegavam a um acordo, em 30 de dezembro de 1902, resolveram apelar para um Tribunal de Arbitragem, denominado Juris Villazón-Osna, em homenagem aos dois ministros das relações exteriores que o subscreveram e foi presidido pelo então presidente da Argentina Júlio Argentino Roca.

Quando da assinatura do Tratado de Petrópolis, em 17 de novembro de 1903, as autoridades peruanas protestaram com veemência, pois o tratado legislou sobre uma área que, sob a ótica peruana, estava em litígio entre o Peru e a Bolívia.

\subsection{A GUERRA DO PACÍFICO}

A segunda disputa internacional da Bolívia aconteceu com o Chile na chamada "Guerra do Pacífico" (1879-1884), em um momento de crescimento da economia chilena e de declínio da economia boliviana.

Essa guerra foi produto de um conflito originado em 1842, em função da descoberta da aplicabilidade agrícola do nitrato de sódio (salitre) e do guano (adubo natural rico em nitrogênio), no deserto de Atacama que, até então, junto ao Pântano de Tamarugal, eram áreas repulsivas, mas com grande potencial mineral, que apresentavam limites imprecisos entre o Peru, o Chile, a Argentina e a Bolívia, pois

Na época colonial, o Vice-Reinado do Peru e a Capitania Geral do Chile separavam-se pelo deserto de Atacama, naquele 
momento, de escasso interesse econômico e quase desabitado. Esse deserto tem como limite sul o rio Salado ou Papozo, aos 25 $30^{\prime}$ de latitude sul. E, com a independência das antigas colônias, as sucessivas constituições chilenas registraram esse deserto como sendo o limite norte da república. (SANTOS, 2002, pp. 114-115)

Portanto, enquanto essa região não possuía atrativos econômicos que justificassem sua ocupação, a definição das fronteiras entre Bolívia, Chile e Peru se arrastava lentamente, mantendo-se até então como fundo territorial. A partir das descobertas de suas potencialidades econômicas, essa região fronteiriça passou a ser alvo de interesse dos governos em questão e das grandes empresas estrangeiras interessadas na extração dos minerais existentes.

O guano, palavra de origem quéchua, tornou-se um produto bastante atrativo na Europa, segundo Martínez Alier (2007), em função do nascimento da química agrícola em 1840, e foi importante para enriquecer o empobrecido solo europeu, além de aumentar a produtividade e atender às demandas inglesas, rendendo altos dividendos aos comerciantes do produto.

Proveniente das fezes de aves migratórias, o guano está relacionado com o fenômeno da ressurgência, que é consequência da ação da corrente marítima fria de Humboldt, que se desloca no sentido norte, em uma linha paralela ao litoral oeste da América do Sul. Na costa peruana, as águas superficiais se aquecem e sofrem um deslocamento, devido à ação dos ventos locais, afastando-se do litoral. A massa de água fria, que se encontrava nas profundezas, aflora, trazendo consigo nutrientes (plânctons) que estavam no fundo do mar, aumentando consideravelmente a quantidade de peixes nesse litoral.

Alimentadas pelos cardumes, as gaivotas e as alcatrazes excretaram durante milhares de anos muitas toneladas de matérias fecais, guano, ricas em nitrogênio, fosfatos e amoníaco. A ausência de chuvas contribui decisivamente para que o material fecal não perdesse suas propriedades químicas.

Quanto ao salitre (nitrato de sódio), é um mineral que pode ser usado na confecção de explosivos, como conservante de embutidos de carne e também 
fazer parte da composição de fertilizantes. Esse mineral foi encontrado em grandes quantidades na província de Tarapacá, no Peru, e na província de Antofagasta.

A partir de 1840, capitais de empresas chilenas, francesas e inglesas passaram a controlar a extração do cobre e, sobretudo, do guano. No final da década de 1850, descobriram-se vultosas reservas de salitre no deserto de Atacama, que começaram a ser explorados por capitais ingleses e chilenos e que investiam pesadamente nas empresas extratoras da Bolívia e do Peru. A Inglaterra se transformou no principal comprador desses produtos, revendendoos ao mercado europeu. Bonilla (2009) ressalta que a partir das descobertas realizadas nessa faixa litorânea, os portos bolivianos de Cobija e Antofagasta passaram a ser habitados essencialmente por chilenos, que representavam cerca de $90 \%$ da população local.

Observa-se, portanto, que a exploração das riquezas não era realizada pela elite boliviana que estava atrelada à extração da prata. Era uma área que, apesar de pertencer à Bolívia, o Estado não se fazia presente.

Como se observa nos escritos de Santos (2002), no ano de 1874 havia um acordo estabelecido entre Bolívia e Chile, que protegia o capital chileno de novos impostos por um período de 25 anos e estabelecia a fronteira entre os dois países no paralelo $24^{\circ} \mathrm{S}$. Porém, em fevereiro de 1878, o governo boliviano decidiu aumentar os impostos em 10 centavos sobre cada 100 quilos de salitre extraídos desde 1874 entre os paralelos $23^{\circ} \mathrm{S}$ e $24^{\circ} \mathrm{S}$, pagos pelas salitreiras estrangeiras para reforçar o caixa estatal do governo boliviano que, apesar do ressurgimento da economia mineira na segunda metade do século XIX, principalmente da ativação da mina de Caracoles no sudoeste da Bolívia, apresentava

dificuldades de transporte interno e da subsequente orientação econômica imposta pelas estradas de ferro, a indústria mineira da Bolívia não conseguiu (pelo menos naquela época) contribuir para o desenvolvimento da agricultura. Ao contrário, ela facilitou a expansão das exportações chilenas de trigo e de farinha, um processo que por sua vez transformou Cochabamba e Chayanta, regiões tradicionais de agricultura 
comercial, em áreas de economia de subsistência. (BONILLA, 2009, p. 583)

Klein (2008) argumenta que, na medida em que se dava o ressurgimento da mineração da prata no período em questão, a economia boliviana tornavase cada vez mais vulnerável às forças econômicas mundiais, pois esse período coincide justamente com a queda do valor da prata no mercado mundial, forçando a elite mineira a buscar a redução dos custos de produção via modernização das minas, com a utilização da eletricidade e máquinas modernas, além da modernização dos meios de transporte para obter maior eficiência na produção e escoamento da matéria-prima.

Nesse sentido, vários projetos ferroviários são propostos no Parlamento boliviano.

Somente em 30 de janeiro de 1873, contudo, que é inaugurada a primeira ferrovia ${ }^{11}$ boliviana, ligando a área mineira de Caracoles até Mejillones, próxima ao porto de Cobija, em Antofagasta, construída pela Companhia de Salitres de Antofagasta.

A elite mineira boliviana adota um discurso modernizante ao defender a construção de ferrovias na Bolívia, no sentido de inserir o país no processo civilizatório causado pelo contato mais direto com as grandes potências europeias e estadunidenses.

A construção da Ferrovia Antofagasta-Bolívia, de propriedade da firma inglesa The Antofagasta and Bolivia Railway Company Limited, que ligava Antofagasta à cidade de Uyuni, no departamento de Potosi, é concluída em 30 de outubro de 1889. Daí partia dois ramais, um para a cidade de Oruro e outro para a cidade de Huanchaca, também em Potosi, que foram concluídos em 15 de maio de 1892.

O dinheiro para tal modernização extrapolava a capacidade de financiamento por parte do Estado, deixando, portanto, tal tarefa para os banqueiros estrangeiros, aumentando ainda mais a dependência externa da Bolívia.

O aumento nos impostos pedidos pela Bolívia também coincidiu com um período de recessão da integrada economia chilena, em função da crise

\footnotetext{
${ }^{11}$ Essa ferrovia foi destruída pela ação de um terremoto em 9 de maio de 1877.
} 
mundial iniciada na década de 1870, fazendo com que o Chile, nesse período, perdesse mercados, sendo obrigado a desvalorizar sua moeda, sofrendo, consequentemente, um período inflacionário.

Caso o pagamento não acontecesse, o governo boliviano ameaçava encampar e vender em leilão a gigantesca empresa concessionária extratora de salitre, a anglo-chilena Companhia de Salitres de Antofagasta, proprietária também da Ferrovia de Antofagasta, da qual diversos políticos chilenos possuíam ações, até alcançar a cifra de noventa mil dólares.

O governo chileno reagiu enviando seu exército para as províncias de Tarapacá e Antofagasta. Conforme Bonilla (2009), em fevereiro de 1879 o porto boliviano de Antofagasta foi ocupado pelos chilenos. Em abril do mesmo ano, o Chile declara guerra ao Peru e à Bolívia, ocupando, sucessivamente, todo o litoral boliviano e as províncias peruanas de Tarapacá, Tacna ${ }^{12}$, Arica e a capital Lima.

Collier (2009) escreve que nenhum dos países envolvidos no conflito estava preparado para a guerra. O Chile, num período de recessão, tinha reduzido seu efetivo, além de ser pequeno e mal equipado. Já os exércitos do Peru e da Bolívia tinham oficiais em excesso. A Bolívia não tinha marinha de guerra. Pelo mar, tanto o Peru quanto o Chile se equiparavam, portanto, o destino da guerra seria resolvido nos confrontos marítimos.

Em outubro de 1879, a marinha chilena encurralou e venceu o encouraçado peruano Huascar. Começou aí o domínio marítimo chileno, que deu fôlego para que as forças terrestres do Chile pudessem avançar, conquistando diversas posições.

A Bolívia foi derrotada no final de 1879, tornando-se um mero espectador da guerra que se travava ainda entre Chile e Peru. A perda do território boliviano para o Chile se concentrou na área litorânea, exatamente na região em disputa econômica, não se estendendo para o planalto, deixando claro que os interesses econômicos impõem uma definição clara dos limites.

A chamada Guerra do Pacífico encerrou-se após vitórias chilenas consecutivas contra as esquálidas forças peruanas. O governo peruano aceitou

\footnotetext{
${ }^{12}$ Devolvida posteriormente para o Peru.
} 
a derrota assinando do Tratado de Ancón, em 20 de outubro de 1883, com rígidos termos de paz impostos pelo governo chileno.

Tarapacá foi cedida em caráter definitivo ao Chile, que ainda recebeu a posse temporária de Tacna e Arica - acerca das quais desenvolveu-se uma longa disputa diplomática que somente veio a ser resolvida em 1929. Os últimos soldados chilenos deixaram o Peru em agosto de 1884. O armistício com a Bolívia (abril de 1884) permitiu ao Chile continuar no controle do Atacama até a negociação de um acordo de paz definitivo, que somente se materializou em 1904. (COLLIER, 2009, p. 624)

Ao final desse segundo conflito, os chilenos mais uma vez são reconhecidos como a força militar dominante no Pacífico Sul da América (SANTOS, 2002) e (BRUIT, 1985), tendo os impérios britânico e brasileiro como aliados.

Para o Chile, a importância de uma aliança com o Brasil residia na possibilidade de o Brasil conter uma possível aliança da Argentina com o Peru e a Bolívia, o que seria desastroso para as pretensões chilenas. Para o Brasil, a importância da aliança com o Chile recaía exatamente no mesmo mérito, ou seja, suprimir os riscos de uma possível frente argentino/chilena contra os interesses brasileiros.

Segundo Santos (2002), baseado na análise documental de Victor Kiernan e de Héctor Bruit, a Guerra do Pacífico não foi fruto do imperialismo inglês, apesar de possuir as características de uma guerra imperialista, mas foi gerada por interesses locais da burguesia chilena e que, apenas no final da guerra, o capital inglês predominou, não como objetivo, mas como resultado. Ao encontro dessa afirmação, Bruit escreveu que

A burguesia chilena lança o país na guerra para defender seus próprios interesses econômicos, que muitos anos antes haviam se concentrado no norte, primeiro na exploração da prata e depois do cobre e finalmente no guano e no salitre. Estes últimos estavam em territórios que vinham sendo disputados 
pelo Chile e Bolívia desde 1842. A anexação do território peruano de Tarapacá obedeceu à sua importância econômica, às grandes inversões chilenas e à garantia de que o Chile considerou necessário proteger a fronteira norte do país de qualquer futura pretensão de peruanos e bolivianos. (BRUIT, 1985, p. 90)

Conforme esse autor foi exatamente o processo de internacionalização do capital que permitiu, num primeiro momento, a ação de setores da burguesia chilena e, num segundo, a perda dessa riqueza para a burguesia inglesa que, no pós-guerra, começou a controlar o comércio e as estradas de ferro construídas para esse fim.

Blakemore (2008) afirma que o Chile teve seu território aumentado em torno de um terço, avançando cerca de 900 quilômetros ao norte, além de conseguir a posse de uma região rica em minerais que lhe propiciaram, nos quarenta anos seguintes, aproximadamente a metade da receita do Estado chileno.

Até hoje a Bolívia se ressente dos $120.000 \mathrm{~km}^{2}$ perdidos para o Chile nessa guerra e ainda guarda, no Lago Titicaca, sua pequena frota da Marinha de Guerra, esperando que um dia seu território, perdido na Guerra do Pacífico, seja devolvido. Para o Chile, esse assunto está absolutamente superado com a assinatura do Tratado de Paz e Amizade de 1904 (Mapa 10, página 131).

No que tange à saída boliviana para o Pacífico, foi firmado entre os governos chileno e boliviano um acordo, em de 20 de outubro de 1904, o Tratado de Paz e Amizade firmando em Santiago, ratificado em La Paz em 10 de março de 1905, de cessão do litoral marítimo "a cambio de 300.000 libras esterlinas y de la construcción del ferrocarril Arica-La Paz por parte Del vecino país." ${ }^{13}$ (GUMUCIO, 1996, p. 20) Ou seja, o governo boliviano cede ao Chile todo o território litorâneo, além de desistir de possuir um porto no Pacífico, em troca de uma compensação monetária e da construção, por parte do Estado chileno, da ferrovia citada por Gumucio.

Como consta na análise de Wasserman, a

\footnotetext{
${ }^{13}$ Tradução livre: Em troca de 300.000 libras esterlinas e da construção da ferrovia Arica - La Paz, por parte do país vizinho.
} 
ausência de uma saída soberana para o mar ou a falta do 'litoral' deixou a Bolívia em segundo plano da DIT (Divisão Internacional do Trabalho) ou duplamente dependente; por um lado, os centros hegemônicos do capitalismo e, por outro lado, os países vizinhos que pudessem prover a comercialização dos seus produtos por via marítima. Com isso, o país empobreceu muito e manteve um padrão de desenvolvimento baixo em relação aos demais países da região. (WASSERMAN, 2004, p. 340)

Tamanha foi a perda territorial e os problemas daí advindos para a Bolívia que Bruit (1985) afirmou, após o conflito, que o Chile transformou-a num país "vassalo", numa "possessão comercial" do Chile. Bruit chegou a comparar, naquele momento histórico, o Chile como se fosse uma Inglaterra sulamericana e a Bolívia como sua "Índia vizinha".

Alvarado (2004) afirma que a perda do acesso ao Pacífico é uma das causas do atraso econômico da Bolívia, que gasta por ano cerca de $10 \%$ do seu Produto Interno Bruto para remediar a falta de acesso ao mar.

De acordo com Vizentini (2004), o Chile afirma que desde a assinatura do Tratado, em 1904, vem proporcionando vantagens portuárias à Bolívia, como ofertar a abertura dos portos de Arica e Antofagasta ao livre trânsito para as mercadorias bolivianas, além de conceder nos portos acima citados

um espaço de $30.000 \mathrm{~m}^{2}$ de zona portuária para as mercadorias de importação boliviana, além de $10.000 \mathrm{~m}^{2}$ para cargas perigosas. Contudo esse espaço é pago pelo governo boliviano ao Chile. E o que almeja o governo boliviano é a concessão definitiva de espaços portuários, sem a necessidade de pagamento de tarifas pelo uso dos portos. Ou seja, a Bolívia busca a criação de portos bolivianos dentro do território chileno. (VIZENTINI, 2004, p. 372) 
Vale ressaltar que esse conflito serviu para uma nova tentativa de construir uma Federação entre Bolívia e Peru, ocorrida em 1880. Conforme Santos

O desalento atingiu os aliados e, talvez como forma de superálo, em junho de 1880, os plenipotenciários Pedro José Calderón, do Peru, e Melchor Terrazas, da Bolívia, reuniram-se com o objetivo de estabelecer uma federação entre os dois países. O ministro brasileiro em La Paz, em resposta a sua consulta sobre a posição do império frente a tal hipótese, foi informado que 'o Brasil não tem interesse em contrariar a execução do plano, aí concebido, de uma confederação entre a Bolívia e o Peru' e instruído a 'limitar-se a informar o governo imperial do que for ocorrendo'. A ideia dessa confederação, no entanto, não prosperou. (SANTOS, 2002, p. 139)

Por outro lado, a derrota boliviana marca o fim dos governos caudilhos e o início de governos civis oligárquicos, com uma acentuada presença da elite mineira que necessitava de governos civis estáveis, a fim de colocar os recursos estatais a serviço de suas necessidades.

Nesse período, mesmo com a queda do preço da prata no mercado internacional e a consequente decadência da produção, a elite mineira faz ascender a produção do estanho e transfere a infraestrutura montada para a prata para o novo mineral.

A chamada Revolução Federal ocorrida em 1899, fruto da substituição da elite argentífera pela elite estanhífera, tirou os conservadores do poder, alçando os liberais ao governo. Porém, quase nada mudou, a não ser a transferência da capital de Sucre para La Paz, transformando-a "en el primer centro administrativo y político de la revolución Federal de 1899". (GARCIA, 2000, p. 2)

No plano externo, os liberais procuraram definir rapidamente as pendências fronteiriças tanto com o Chile e com o Brasil, para garantir a continuidade do processo de ampliação e construção de ferrovias, tão necessárias ao comércio internacional de um país agora mediterrâneo. 
Klein enfatiza que, apesar das perdas territoriais, as finanças bolivianas começaram a dar sinais de superávit, graças à expansão da exportação de estanho a partir de 1899, chegando a representar um quarto do total mundial. Isso encorajou o governo liberal a conseguir um grande empréstimo, em 1906, com um banco privado estadunidense para a conclusão das

ligações ferroviárias internacionais com a construção de ramais para as principais cidades interioranas de Cochabamba e Sucre, bem como as ligações internacionais com os centros mineiros de Potosi e Oruro. Construiu uma nova ferrovia para Guaqui, no lago Titicaca ligando-se à rede ferroviária peruana. Executou os principais projetos de construção urbana, saneamento e iluminação, acarretando uma grande expansão da atividade econômica, até a crise de 1913-1914, às vésperas da Primeira Guerra Mundial. (KLEIN, 2008, p. 396)

A partir desse momento tem início, segundo Chiavenato (1981), à dívida externa boliviana, encetada para fornecer infraestrutura de exportação para a indústria estanhífera, uma vez que o governo quase não cobrava impostos dessas companhias e investia grande soma de divisas próprias ou emprestadas para o transporte do mineral.

De acordo com Ayerbe (2002), é um momento de dinamismo do capitalismo europeu. A especialização produtiva se intensifica especialmente na América Latina. Os investimentos estrangeiros se avivam, principalmente por meio de empréstimos para serem investidos na infraestrutura ligada ao comércio de exportação, por isso, nesse contexto, as ferrovias ganham um grande impulso. No ano de 1912, a Bolívia já possuía uma rede ferroviária de 1.196 quilômetros.

Paradoxalmente, na medida em que o comércio exterior abastecia a Bolívia de produtos importados, as áreas produtoras no interior da Bolívia entravam em declínio produtivo, uma vez que seus produtos estavam mais caros do que os importados. Tal fato gera um desincentivo para a construção de vias de ligação internas. 
As ligações ferroviárias para Arica, no litoral do Pacífico, ficaram a cargo do governo do Chile, que estabeleceu também o itinerário a ser seguido pela ferrovia. Em 13 de maio de 1913, o Chile terminou a construção da ferrovia prevista no Tratado de Paz e Amizade. A propriedade da seção boliviana da estrada de ferro Arica-La Paz foi transferida para a administração boliviana após quinze anos contados do dia em que a ferrovia foi totalmente construída, pois a negociação estabeleceu que o Chile administrasse a ferrovia por quinze anos, tempo suficiente para reaver o dinheiro gasto na construção da estrada de ferro.

A partir de 1928, a administração da ferrovia foi separada em dois setores. O primeiro, no território chileno, de Arica até Visviri, controlado por seu governo; o segundo, em território boliviano, de Charanã até La Paz, sob responsabilidade da Bolívia.

Devido ao alto grau de inclinação da montanha, um dos instrumentos utilizados na construção da ferrovia foi a cremalheira ${ }^{14}$, porém a utilização de vagões com cargas muito pesadas era desaconselhável, prejudicando dessa forma as exportações bolivianas pelo porto de Arica, que respondia por mais de 80\% do comércio externo boliviano. Em função desse entrave, a ferrovia foi perdendo importância quando do início da operação de uma rodovia que liga La Paz a Arica.

\subsection{A QUESTÃO DO ACRE}

Nos estertores do século XIX, eclodiu a rebelião no Acre, que se prolongou por três anos e, ante a ameaça de uma intervenção direta do governo brasileiro, foi firmado entre os governos da Bolívia e do Brasil o Tratado de Petrópolis, em 1903, no qual a Bolívia cederia o território do Acre ao Brasil em troca de dois milhões de libras esterlinas e o governo brasileiro se comprometeria a construir a estrada de ferro Madeira-Mamoré, para superar o trecho encachoeirado do rio Madeira, possibilitando o acesso das mercadorias

\footnotetext{
14 Trilho dentado instalado no centro dos trilhos paralelos de uma ferrovia, para que a locomotiva encaixe uma engrenagem para vencer terrenos íngremes.
} 
bolivianas aos portos brasileiros do Atlântico (inicialmente Belém do Pará, na foz do rio Amazonas).

A questão do Acre não deve ser analisada isoladamente, mas num contexto maior de disputas fronteiriças e de navegabilidade dos rios lindeiros de Brasil e Bolívia. Segundo Mattos, "a questão acreana foi o subproduto da valorização de áreas fronteiriças não demarcadas, alcançadas pelo surto econômico da borracha". (MATTOS, 1980, p. 50)

Até o final do século XIX, a fronteira entre Brasil e Bolívia foi alvo de constantes embates entre os dois países, apesar de estarem estabelecidas pelo Tratado de Ayacucho, de 1867.

No século XVIII, o império português envia à área em questão pelo menos quatro expedições. Ferreira (2005) relata que entre 1722 até 1788, quatro expedições oficiais foram enviadas para a região fronteiriça entre Brasil e Bolívia, principalmente ao complexo Madeira-Mamoré, sendo duas de exploração, uma de engenheiros e outra de cientistas. "As duas primeiras, chefiadas por dois sargentos-mores: Francisco de Melo Palheta, em 1722, e Luís Fagundes Machado, em 1749. A de engenheiros, chefiada por Francisco José de Lacerda e Almeida, em 1781 e a expedição filosófica (científica), de Alexandre Rodrigues Ferreira, em 1788" (FERREIRA, 2005, p. 52), atestando a importância que essa reserva territorial despertava desde os tempos do Brasil colônia, tendo a expedição de Francisco de Melo Palheta chegado até a localidade de Santa Cruz de Cajuava, nas proximidades de Santa Cruz de la Sierra. Em 1732, as autoridades portuguesas resolveram fechar a navegação do rio Madeira, face ao prodigioso processo de ocupação e colonização de Mato Grosso em função da descoberta de ouro em Cuiabá, no ano de 1718.

De acordo com Bandeira (1985), a primeira rusga entre o Brasil e a Bolívia aconteceu logo após a independência boliviana, em 1825, quando o governador da província boliviana de Chiquitos, próxima ao Brasil, se dirigiu ao Mato Grosso e colocou-a sob proteção do império brasileiro. O governo de Mato Grosso, em 14 de abril de 1825, aceitou a anexação, porém, em 21 de maio do mesmo ano, o governo de Mato Grosso, instigado pelo governo imperial brasileiro, voltou na decisão adesista da referida província boliviana, evitando, assim, qualquer possibilidade de um confronto armado com o recémindependente Estado boliviano. 
No ano seguinte, uma questão bastante interessante chama a atenção. O governo imperial brasileiro recebe um pedido de cidadãos estadunidenses, respaldados pelo governo do seu país, para franquear a navegação no rio Amazonas e seus afluentes. Tal pretensão foi logo rejeitada pelo império sob a alegação de que tal liberação pudesse ofender a soberania nacional.

De acordo com Tocantins (1979), em julho de 1834, o presidente boliviano Andrés de Santa Cruz enviou um emissário ao Brasil na tentativa, mal sucedida, de celebrar um acordo de fronteiras.

Nova busca de acordo ocorreu em 1842, quando o governo boliviano autorizou um grupo inglês a colonizar parte de seu território às margens do rio Paraguai. Mais uma vez o governo imperial brasileiro rechaçou qualquer possibilidade de navegação estrangeira em águas interiores do território brasileiro.

Em 1844 mais uma ensaio de navegação, desta vez pelas águas do complexo Madeira-Mamoré foi impedida. Uma embarcação francesa, sob os auspícios do governo boliviano requer, sem sucesso, uma concessão de navegação.

Tavares Bastos (1937) escreve que, em 1852, os tenentes W. L. Herndon e L. Gibbon, em missão oficial da Marinha estadunidense, exploraram os rios que ligam a Bolívia ao litoral atlântico brasileiro, pelo vale do Amazonas, traçando um dos mapeamentos mais detalhados da região. Tais estudos, segundo Tavares Bastos, podem ser encontrados na publicação "Exploration of the valley of the Amazon", escrita pelos dois tenentes e publicada em Washington no ano de 1854.

Os estudos da dupla de militares estavam ligados à necessidade de diminuição no tempo de viagem das mercadorias exportadas dos Estados Unidos para a Bolívia. Nos cálculos realizados por eles, a rota BaltimoreCochabamba, usando os rios da bacia amazônica, levaria aproximadamente 51 dias e até La Paz, a capital, aproximadamente 59 dias, contra os 180 dias, até então gastos no trajeto via porto de Arica, e o posterior contorno do Cabo Horn, no Chile, ponto mais ao sul da América do Sul, que demarca a divisão entre os Oceanos Atlântico e Pacífico.

Pressões foram feitas no início da década de 1850 por parte do governo estadunidense que enviou, entre 1853 e 1855, seu ministro plenipotenciário 
General Willian Trousdale, para quebrar a resistência do governo brasileiro para a abertura da navegação fluvial em águas interiores do país, mas tal ação se revelou um fracasso, pois a alegação brasileira era, segundo Bandeira "que um Estado ribeirinho, com controle da boca do rio, poderia fechá-lo, se o governo ribeirinho a montante não acatasse seus regulamentos de segurança". (BANDEIRA, 1985, p. 78) Além disso, os governos brasileiro e boliviano não tinham nenhum acordo sobre a navegação, tanto é que nem os navios com bandeira boliviana poderiam transitar nas águas brasileiras, pois, talvez, poderiam acobertar navios estadunidenses sob sua bandeira.

A pressão ficou maior ainda quando o império brasileiro se recusou "a aderir ao Tratado de Livre Navegação, celebrado pela Confederação Argentina com a Grã-Bretanha, França e Estados Unidos, em 1853, e manteve a Bacia do Amazonas fechada ao trânsito de navios estrangeiros, resistindo a todas as pressões daquelas três potências, bem como da Bolívia, Equador, Peru, Nova Granada e Venezuela, que eram ribeirinhos e se localizavam à montante." (ibidem, p. 94)

Segundo Santos (2002), vários insucessos marcaram a tônica das negociações bilaterais como a missão de Duarte da Ponte Ribeiro (1851-1852), quando o diplomata brasileiro sequer foi recebido pelo presidente boliviano Belzú e a investida de João da Costa Rego Monteiro, em 1860, procurando neutralizar as investidas estadunidenses. Tanto é que um grande momento de tensão ocorreu em 27 de janeiro de 1853, quando o governo boliviano promulgou um decreto declarando livres ao comércio e navegação estrangeiros todos os rios que banhavam seu território e fluíam para o rio Amazonas e para a bacia do Prata, além de estabelecer um prêmio de US\$10.000 para o primeiro navio estrangeiro que atracasse em algum porto boliviano, causando um grande mal-estar entre os governos da Bolívia e do Brasil.

Sentindo-se isolado e pressionado, o governo brasileiro, na figura do Ministro Paulino Soares de Souza, já demonstrava certo incômodo com tal posição inflexível, pois, em suas palavras, era "incompatível com a civilização e tendência do século", mas também era uma forma de "Em troco da concessão da navegação dos rios, podemos exigir que as dúvidas relativas às fronteiras sejam resolvidas em nosso favor". 
Esse problema só seria resolvido com o Tratado de Amizade, Limites, Navegação, Comércio e Extradição (Tratado de Ayacucho), entre Brasil e Bolívia, assinado em 27 de março de 1867, pelo conselheiro imperial e ministro plenipotenciário Felipe Lopes Netto e pelo presidente da Bolívia General Mariano Melgarejo, no qual a Bolívia perdeu a margem direita do rio Paraguai e uma larga faixa de terra entre a foz de Beni e o Javari. Dessa forma, estava acertada a fronteira entre os dois países. A assinatura do Tratado provocou a imediata ampliação da navegação de embarcações estrangeiras na região, que despertava um grande interesse por parte dos países imperialistas.

Novos conflitos vieram a acontecer na última década do século XIX em função de problemas na demarcação dos marcos fronteiriços entre os dois países, principalmente no que tange à definição dos limites entre os rios Madeira e Javari.

Conforme Bandeira (2000), essa área escassamente habitada começou a receber, a partir do início da década de 1870, milhares de brasileiros, vindos sobretudo do estado do Ceará, fugindo da seca e atraídos pela promessa de riqueza, eles começaram a ocupar uma extensa área de terras que, apesar de pertencerem à Bolívia, nunca foram, efetivamente, ocupadas por bolivianos em função da dificuldade de acesso. Os brasileiros se dirigiam aos seringais para trabalharem na extração da borracha, cujo consumo, graças ao descobrimento da técnica de vulcanização e seu emprego nas indústrias dos Estados Unidos e da Europa, crescia rapidamente.

Apesar da assinatura do Tratado de Amizade, Limites, Navegação, Comércio e Extradição, entre Brasil e Bolívia, os limites não tinham sido demarcados. Garcia (2009) escreve que a ausência de demarcação entre os dois países fazia com que os proprietários brasileiros e mesmo bolivianos alargassem o limite de suas terras na direção do país vizinho para que, quando houvesse o processo demarcatório, as terras fossem reconhecidas como suas e, portanto, pertencentes ao Brasil.

De acordo com Sena (2002), a questão dos marcos fronteiriços só se resolveria em 23 de setembro de 1898, depois de três anos de negociações, quando o Brasil reconheceu que o território de Aquiri seria definido pela Linha Cunha Gomes, considerando-o boliviano. 
Bandeira (2000) assinala que o ministro boliviano José Paravicini, aproveitando o acordo, funda em janeiro de 1899 o povoado de Puerto Alonso, com apoio do governo brasileiro, em homenagem ao então presidente boliviano Severo Fernandes Alonso, além de legislar sobre a navegação dos rios da região. Esses foram abertos ao tráfego internacional, estabeleceram-se taxas aduaneiras e impostos de comercialização, trazendo enormes prejuízos para a província do Amazonas.

Tais atitudes do representante boliviano não foram bem aceitas pelas autoridades amazonenses, pois a instalação de um posto fiscal

vinha criar dois males para o tesouro amazonense. O primeiro, a perda de rendas provenientes do território ocupado pelos estrangeiros, inclusive as taxas que incidiam na borracha em trânsito por Manaus. O segundo, resultava num problema sutil: como saber se a borracha procedia, realmente, de seringais além ou aquém da linha Cunha Gomes? (TOCANTINS, 1979, v.1, p. 208)

Em 14 de julho de 1899, o espanhol Luiz Galvez Rodriguez de Arias, a soldo do presidente da Província do Amazonas, Coronel Ramalho Júnior, toma Puerto Alonso e declara o Estado Independente do Acre, solicitando o reconhecimento do novo Estado ao Brasil, porém, a solicitação foi recusada pelo governo brasileiro. Essa aventura durou até março de 1900, quando uma coluna militar organizada pelo governo brasileiro terminou com Estado recémfundado e devolveu-o para a Bolívia.

Batalhas foram travadas entre exércitos particulares organizados pelos "barões da borracha" e o exército boliviano, porém, sem intervenção do exército brasileiro.

Nessa área, a presença de população boliviana era mínima. Apesar de tentar deslocar pessoas para a área, o governo da Bolívia "mostrou-se incapaz de ocupar a região que reivindicava". (MATTOS, 1980, p. 59)

Bandeira (2000) coloca que, para ocupar e administrar a área por um período de trinta anos, o governo boliviano, por intermédio de Felix Avelino Aramayo, seu representante na Grã-Bretanha, fechou um acordo, em 11 de 
junho de 1901, com a companhia colonial The Bolivian Syndicate of New York City in North America ${ }^{15}$, cujo presidente indicado era primo de Theodore Roosevelt, o novo presidente dos Estados Unidos da América.

A empresa colonial "tinha em mira administrar e explorar as riquezas naturais do Território do Acre, por um período de 30 anos, competindo-lhe auferir os proventos, $60 \%$ dos quais para o governo boliviano e $40 \%$ para o sindicato". (TOCANTINS, 1979, v.2, p. 24)

Vale ressaltar que um dos sócios famosos da empresa era August Belmont, representante do banqueiro inglês Barão de Rothschild.

Nas palavras de Doratioto:

uma empresa estrangeira, o Bolivian Syndicate. O Sindicato, como essa empresa ficou conhecida, era formado por firmas inglesas e norte-americanas. Ele recebeu autorização de La Paz para explorar e administrar o território acreano, podendo nele arrecadar impostos, organizar polícia, manter tropas e barcos de guerra. Enfim, a Bolívia praticamente transferia sua soberania (no Acre) para uma empresa privada. (DORATIOTO, 1994, p. 77)

Garcia (2009) salienta que a presença de uma companhia nesses moldes abriria as portas da América do Sul ao colonialismo, tanto estadunidense quanto inglês, pois naquele momento o governo dos Estados Unidos era simpático ao governo da Bolívia. Este propôs aos Estados Unidos que em troca do seu apoio e proteção na questão do Acre, daria garantias alfandegárias para os Estados Unidos, além de, se necessário, "abriria mão de sua soberania sobre o território disputado com os brasileiros, em favor dos norte-americanos." (GARCIA, 2009, p. 197)

Tocantins (1979) elenca alguns itens constantes no acordo entre a Bolívia e os Estados Unidos, em que estes:

a) questionariam, via diplomática, a posse do território do Acre pelo Brasil;

\footnotetext{
15 "Uma chartered company, do tipo que os europeus contratavam para explorar suas colônias africanas". (MATTOS, 1980, p. 59)
} 
b) forneceriam armas e dinheiro, caso acontecesse um conflito armado entre o Brasil e a Bolívia;

c) forçariam a constituição de uma comissão para a correta demarcação da fronteira Brasil/Bolívia;

Além disso,

d) instituir-se-ia o livre trânsito pelos rios afluentes do Amazonas para embarcações da ou à Bolívia;

e) versaria sobre vantagens e descontos para mercadorias estadunidenses;

f) estabeleceria que os Estados Unidos, em caso de guerra, pagariam os gastos ocasionados por ela, recebendo em hipotecas e rendas alfandegárias da Bolívia.

Em 1902, em função das medidas draconianas impostas pelo governo boliviano e a presença do Bolivian Syndicate, eclodiu uma nova rebelião de brasileiros, comandada pelo ex-militar José Plácido de Castro e, novamente, com o apoio do presidente da província do Amazonas. De acordo com Sena (2002), o grupo de cerca de oitocentos homens, comandado por Plácido de Castro expulsou tropas bolivianas estacionadas no Acre, ocupou Puerto Alonso e recebeu a rendição do delegado boliviano Lino Romero. Além disso, expulsou da área a diretoria do Bolivian Syndicate para Belém, no Pará, e decretou a segunda independência do Acre.

A preocupação dos barões da borracha com a possibilidade de monopolização do comércio, por parte do Bolivian Syndicate, diminuindo os lucros dos proprietários, tanto brasileiros quanto bolivianos, motivou a rebelião, mostrando que a verdadeira pátria dos capitalistas é o capital.

Em fevereiro de 1903, o presidente brasileiro Rodrigues Alves deu permissão para o deslocamento de tropas brasileiras para a área em litígio, sob o comando do general Olímpio da Silveira, para ocupar a área e retirar o exército de Plácido de Castro. Em 6 de abril de 1903, o general Olímpio da Silveira retira o Coronel Plácido de Castro do poder e assume a autoridade local. É interessante notar que o exército brasileiro assume a autoridade de um território, até então, reconhecidamente pertencente ao Estado boliviano. 
Segundo Tocantins (1979), Plácido de Castro vai até Xapuri tentar constituir um novo governo para o Acre e mantém o propósito de invadir a Bolívia.

Para reprimir os sublevados, o presidente da Bolívia, general José Manuel Pando, prepara pessoalmente uma pequena tropa para marchar contra os brasileiros. Os soldados bolivianos partiram de La Paz em duas colunas. A primeira comandada pelo Ministro da Guerra Ismael Montes e a segunda, sob o comando do próprio general Pando.

As tropas bolivianas e do coronel Plácido de Castro chegam a entrar em conflito quando este recebe um comunicado do general Olímpio da Silveira de que Brasil e Bolívia estão em processo de negociação.

Nesse contexto de crise em que o Bolivian Syndicate se coloca no centro das preocupações do governo brasileiro, assume o Ministério das Relações Exteriores do Brasil, em 3 de dezembro de 1902, o monarquista José Maria da Silva Paranhos Filho, o Barão de Rio Branco que,

contrariando a imagem habitual de um homem afinado com Washington, o Barão se incomodava com avanço dos interesses norte-americanos na região amazônica, e a instalação do Bolivian Syndicate nesse país vizinho, serviu de alerta para que a diplomacia brasileira assumisse uma posição mais firme na questão do Acre. (MARTIN, 2007, p. 47)

Nesse sentido, o Barão de Rio Branco

Inverteu a política seguida pelo Brasil, de reconhecer como indiscutível a soberania boliviana sobre o Acre. Rio Branco declarou o território zona litigiosa, lembrando o artigo XIV do acordo de limites de 1867, o qual afirmava que 'se no ato da demarcação ocorrerem dúvidas graves, provenientes de inexatidão do presente tratado, serão estas dúvidas decididas amigavelmente por ambos os governos'. Rio Branco passou, então a reclamar da Bolívia o território ao norte do paralelo 10 graus 20 minutos. (DORATIOTO, 1994, p. 78) 
Mattos explica que

aceitar como válido o acordo do governo de La Paz com o Bolivian Syndicate, equivaleria a conformar-se com a instalação, no centro da América do Sul, de um poder econômico internacional e área exclusivamente dependente do Brasil para a sua entrada e saída. (MATTOS, 1980, p. 59)

Para impedir a instalação dessa companhia colonial, o governo brasileiro fecha o trânsito de mercadorias que saem ou entram na Bolívia, que tinha sido franqueado por José Paravicini a todos os países que realizassem comércio com a Bolívia.

Apesar de causar um desconforto internacional com os parceiros comerciais bolivianos $^{16}$,

A imprensa norte-americana, inspirada pelos agentes do Sindicato, depois da suspensão do trânsito de mercadorias bolivianas, fizera recrudescer a campanha contra o Brasil, apresentando a Bolívia como um país fraco, vítima de um vizinho poderoso que nem ao menos lhe permitia trânsito pelos rios de único acesso ao território do Acre, para onde o governo boliviano contratara uma forte Company, capaz de desenvolver aquelas terras tão ricas e ainda incultas. (TOCANTINS, 1979, v. 2, p. 188)

Mesmo assim, a decisão é mantida, impedindo dessa forma, o acesso à Bolívia de seus parceiros comerciais e também o trânsito que poderia haver por parte do Bolivian Syndicate pelos rios amazônicos.

Garcia (2009) enfatiza que, nesse ínterim, o governo estadunidense começa a mudar sua posição sobre o conflito, dando sinais de que uma indenização ao Bolivian Syndicate poderia resolver a questão. É nesse momento histórico que os Estados Unidos dão uma guinada em sua política para a América Latina, deixando de lado a política de aquisições territoriais e entrando numa fase de influência hegemônica.

${ }^{16}$ De acordo com Tocantins (1979) o governo brasileiro recebe reclamações formais dos governos da França, da Alemanha e da Grã-Bretanha. 
Tocantins (1979) afirma que o governo brasileiro pagou para essa empresa a importância de 110.000 libras esterlinas para renunciar a quaisquer pretensões no Acre, vale salientar que tal empresa não havia feito investimentos na área. Ironicamente, o banqueiro que emprestou o dinheiro para o pagamento da indenização do Bolivian Syndicate foi o Barão de Rothschild.

Depois disso, o governo brasileiro reabriu a navegação no rio Amazonas, sinalizando que um acordo estava próximo de se realizar.

O acordo entre os dois países foi alcançado em 17 de novembro de 1903, na assinatura do Tratado de Petrópolis, no qual ficou acertada a compra, por parte do Brasil, do território do Acre (mapa 10, página 131) e a construção de uma ferrovia, a Madeira-Mamoré.

Sobre o Tratado de Petrópolis, Tocantins escreveu que

Pelo Tratado, o Brasil incorpora 181.000 quilômetros quadrados de terra, e em troca a Bolívia recebe: 723 quilômetros quadrados sobre a margem direita do rio Paraguai, dentro dos terrenos alagados conhecidos por Baía Negra; 116 quilômetros quadrados sobre a lagoa de Cárceres, compreendendo uma nesga de terra firme (49,6 quilômetros quadrados) que permite o estabelecimento de um ancoradouro mais favorável ao comércio que o que fora cedido à Bolívia em 1867; 20,3 quilômetros quadrados, nas mesmas condições, sobre a lagoa Mandioré; 8,2 quilômetros quadrados sobre a margem meridional da lagoa Guaíba; a construção de uma estrada de ferro, em território brasileiro, ligando Santo Antônio, no Madeira, a Vila Bela, na confluência dos rios Beni e Mamoré; liberdade de trânsito por essa estrada e pelos rios até o oceano, com as correspondentes facilidades aduaneiras, o que já the era facultado por anteriores tratados; finalmente, o pagamento de dois milhões de libras esterlinas em duas prestações. (TOCANTINS, 1979, v. 2, p. 281)

O artigo VII do Tratado de Petrópolis especificava que a ferrovia se estenderia de Santo Antônio, no rio Madeira, até Guarajá Mirim, no rio Mamoré, 
para o escoamento da borracha produzida em território boliviano. Além disso, deveria ter um ramal, nunca construído, que passasse por Vila Murtinho, no Mato Grosso ligando-a à cidade de Vila Bela ${ }^{17}$, na Bolívia, localizada na confluência dos rios Beni e Mamoré. Segundo Bandeira (1998), essa ligação seria muito importante, pois facilitaria a união de La Paz à ferrovia, diminuindo sua dependência da Bacia do Prata. Para facilitar essa junção, estava prevista a construção de uma ferrovia ligando La Paz até Puerto Beni, na cabeceira do rio Beni, mas esse projeto não prosperou, em face da queda do preço da borracha no mercado internacional, além da falta de recursos financeiros por parte da Bolívia.

Esse conjunto ferroviário deveria ser construído num prazo de quatro anos e seria usado por ambos os países, com direito às mesmas tarifas.

Vale notar que os termos gerais do Tratado de Petrópolis, assinado com o Brasil em 1903, são bastante parecidos com o Tratado de Paz e Amizade assinado com o Chile em 1904, por ocasião das negociações decorrentes da Guerra do Pacífico. Em ambos os casos, o governo boliviano, em troca de seu território perdido, contentou-se com uma soma em dinheiro e a construção de uma ferrovia. É a "era dos impérios", na qual os países pobres tinham que cumprir seu papel na Divisão Internacional do Trabalho e a ferrovia tinha uma função primordial nesse processo, no que tange ao escoamento das mercadorias.

A ideia de uma ligação entre a Bolívia e o oceano Atlântico via MadeiraMamoré-Amazonas não vem à tona somente em função do conflito. É um plano que existe desde meados do século XIX.

Para a Bolívia, seria mais fácil descer do altiplano até a planície oriental onde alcançaria os afluentes dos rios do Prata ou Amazonas e, posteriormente, chegaria ao Atlântico. Dessas duas rotas, a mais interessante seria a do rio Amazonas, pois o interior da Bolívia ficaria interligado ao Atlântico, em Belém do Pará, pelos rios Mamoré e Beni, numa rota bem mais próxima da Europa e da costa leste dos Estados Unidos do que a oferecida pelo porto de Buenos Aires. O único obstáculo era a transposição das cachoeiras do rio Madeira.

\footnotetext{
${ }^{17}$ Pela não construção desse ramal, o governo boliviano ainda hoje considera que o Tratado de Petrópolis não foi cumprido.
} 
Desde 1846, o governo boliviano ventilava a possibilidade de emprego do trajeto Beni-Mamoré-Madeira-Amazonas para o escoamento e recebimento de suas mercadorias. Neste mesmo ano, o governo boliviano enviou para a área em questão o engenheiro José Martin Palacios que defendeu, em seu relatório final, a tese da viabilidade de tal rota, relatando, de maneira otimista, que a transposição do trecho encachoeirado era um inconveniente que poderia ser facilmente vencido por meio de uma estrada. Quando os tenentes da marinha estadunidense, W. L. Herndon e L. Gibbon mapearam a área em 1852, defenderam a transposição desse trecho pela construção de uma estrada. Assim, a travessia de aproximadamente 290 quilômetros poderia ser realizada no lombo de animais e duraria cerca de sete dias.

O grande problema, então, era o longo trecho de quedas d'água que se inicia no rio Mamoré que, um pouco mais abaixo, recebe, pela margem esquerda, o Beni, rio de origem andina. É na confluência do rio Beni com o rio Mamoré que nasce o rio Madeira que desce em direção à planície amazônica. Segundo o livro de Manoel Rodrigues Ferreira, A Ferrovia do Diabo, no trecho entre Guajará Mirim e Santo Antônio, de aproximadamente 400 km, existem cerca de sete cachoeiras, dez correntezas e três saltos. E eram justamente esses saltos (Ribeirão, Jirau e Teotônio), além de algumas cachoeiras que tinham de ser contornados por terra.

A ideia de construir uma ferrovia no trecho encachoeirado partiu do general boliviano Quintín Quevedo e do engenheiro brasileiro João Martins da Silva Coutinho. Ambos lançaram a proposta em momentos diferentes, mas no ano de 1861, depois de visitas distintas à área. Para ambos, tal ferrovia deveria correr paralela ao trecho encachoeirados do rio.

Conforme nos relata Ferreira (2005), para o engenheiro brasileiro, o trecho do Madeira-Mamoré deveria ser escolhido como o caminho natural para o escoamento das mercadorias da província brasileira do Mato Grosso, por ser inteiramente brasileiro, podendo animar a ocupação de uma área ainda não povoada e repleta de recursos naturais. Além disso, a navegação pela rota do rio Paraguai poderia ficar para segundo plano, já que esse rio era aproveitado em condomínio com o nada confiável Paraguai. João Martins da Silva Coutinho ainda afirma que a Bolívia só poderá se desenvolver utilizando esse percurso em seu comércio exterior. O Brasil, concedendo esse 'favor' para a Bolívia, 
poderia lucrar bastante com o controle do comércio nessa região. Vale salientar que os projetos territoriais do Brasil império carregavam a questão de se levar a civilização para as áreas distantes, chamadas de sertões, como justificativa para a expansão territorial.

A Guerra do Paraguai (1864 - 1870) veio reforçar a tese de que a província do Mato Grosso e o Estado boliviano não poderiam ficar reféns da utilização do rio Paraguai para alcançar o Atlântico. Tavares Bastos (1866) defende o uso da rota Madeira-Mamoré por parte da Bolívia, argumentando que o comércio exterior desse país faz-se pelos portos do Pacífico, principalmente pelo porto de Arica, na República do Peru e, secundariamente, por seu próprio porto de Cobija.

Até a Guerra do Paraguai, o emprego por parte da Bolívia da saída pelos rios da bacia amazônica era quase nulo, porém, com o conflito, a Bolívia passou a exportar por esse trecho uma quantidade razoável de açúcar, cacau, charutos, charques, couro, graxa e até gado, mesmo tendo de transpor o trecho de cachoeiras do rio Madeira. Para aumentar esse movimento comercial, fazia-se necessária a substituição da travessia por terra, em lombo de animais, por um meio de transporte mais seguro e eficiente. Essa travessia era realizada por "índios locais que levavam semanas para arrastar botes e víveres acima e abaixo dessa barreira. Havia uma trilha de varação através da floresta ao longo do rio, mas isso não resolvia o problema de trazer a borracha boliviana até o curso principal do Amazonas." (HEMMING, 2009, pp. 348-349)

No sentido de viabilizar essa nova rota de comércio, o Brasil procura o governo boliviano para negociar a implantação de uma ferrovia que permitisse suplantar o trecho encachoeirado do rio Madeira. Desse entendimento, surgiu o já citado Tratado de Amizade, Limites, Navegação, Comércio e Extradição, entre Brasil e Bolívia, assinado no dia 27 de março de 1867, pelo conselheiro imperial e ministro plenipotenciário Felipe Lopes Netto e pelo presidente da Bolívia, General Mariano Melgarejo. Esse tratado declarava livre a navegação, as comunicações e o comércio entre os dois Estados pela fronteira comum, além de isentar de impostos qualquer mercadoria que por ali transitasse. Além disso, o governo brasileiro demonstrava sua pretensão de construir uma estrada de rodagem ou de ferro, na margem brasileira do trecho encachoeirado do rio Madeira. 
Hardman (2005) escreve que, no mesmo ano, o governo brasileiro incumbiu os engenheiros alemães Joseph Keller e Franz Keller de estudarem a possibilidade da construção de uma estrada de ferro no local. Posteriormente, os engenheiros avalizaram a construção da tal ferrovia, que deveria ligar as localidades de Santo Antônio e Guajará Mirim, acompanhando aproximadamente o trecho das cachoeiras (Foto 1). Além disso, deveria obrigatoriamente passar em frente à foz do rio Beni, para coletar as mercadorias provenientes daquela região, salientando que essa rota seria de fundamental importância à Bolívia, pois era bem menos penosa que a transposição da vertente andina.

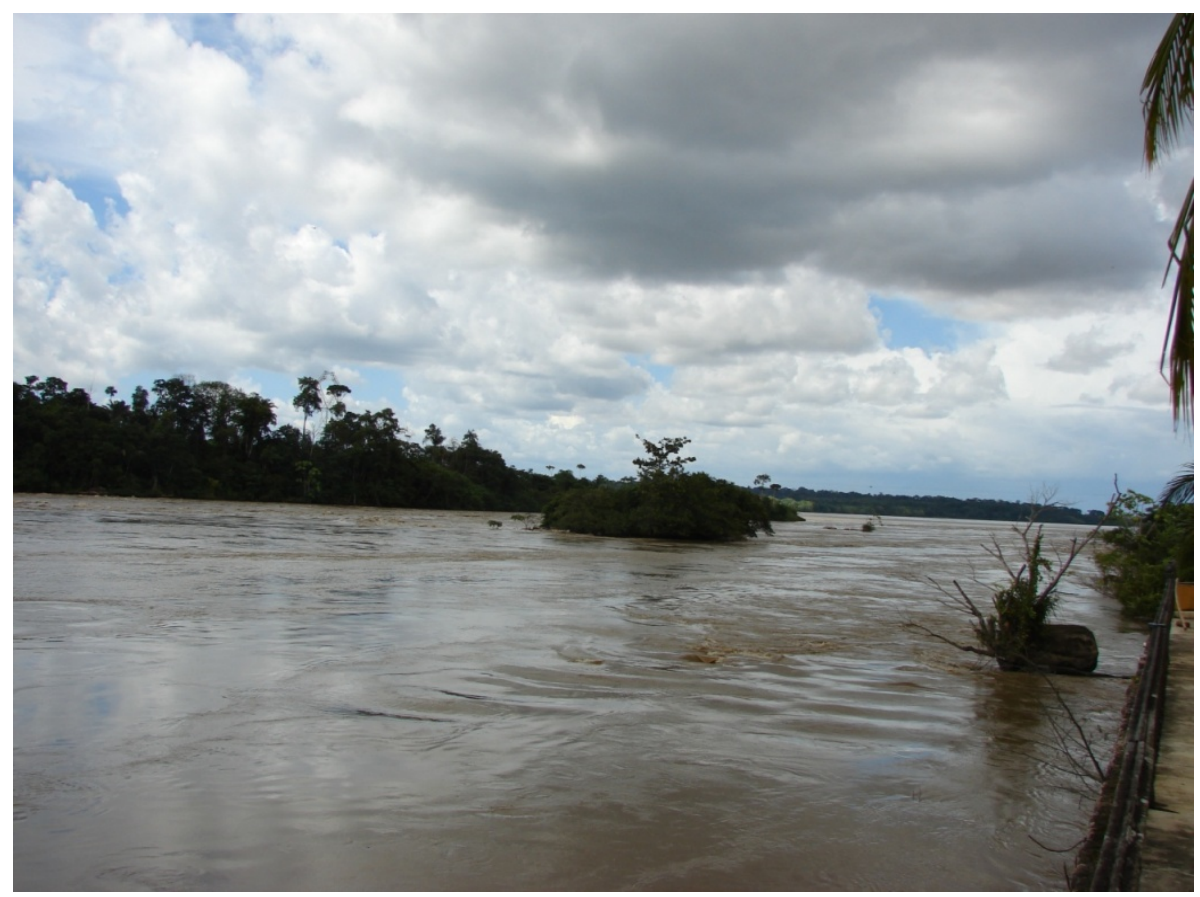

Foto 1 - Cachoeira de Santo Antônio, no rio Madeira.

(Fonte: Maria Keiko Yamauchi, em 28 fev 2008).

Ferreira (2005) salienta que os Keller verificaram empiricamente que uma pequena rota de comércio já existia, ligando a Bolívia ao Atlântico, transportando para os mercados da Europa e dos Estados Unidos couro e gordura e trazendo produtos industrializados dessas praças, pois alguns comerciantes do oriente boliviano preferiam incorrer nos riscos e perigos das cachoeiras a sofrer as dificuldades e despesas da travessia dos Andes. 
O governo boliviano encarregou o engenheiro Quintín Quevedo a procurar interessados em encontrar alternativas viárias que suplantassem a dificuldade de transposição dos rios Madeira e Mamoré. Ele fez contato com o coronel George Earl Church, que se interessou pelo projeto boliviano. No dia 27 de agosto de 1868, ele obteve uma concessão do governo boliviano para organizar e explorar uma companhia de navegação que ligasse o rio Mamoré ao Madeira. A companhia foi batizada com o nome de "National Bolivian Navigation Company". Para tanto, o objetivo principal da companhia era, segundo Hardman (2005), canalizar o trecho encachoeirado dos rios Madeira e Mamoré, permitindo dessa forma a navegação que ligaria a Bolívia ao oceano Atlântico.

O coronel Church, antevendo as dificuldades de construção de canais pelos rios em questão, em 1869, consegue uma alteração no contrato assinado com o governo boliviano no sentido de permitir a construção de uma ferrovia no local, caso ficasse constatada a inviabilidade da construção dos canais. Como a ferrovia deveria ser construída em território brasileiro, ele obtém, em 1870, uma concessão de cinquenta anos do governo brasileiro e exige que Church organize uma nova companhia, que deveria receber o nome de "Madeira and Mamoré Railway Co. Ltd". O governo brasileiro impôs que a ferrovia ligasse Santo Antônio a Guajará-Mirim e deveria ser iniciada dentro de dois anos e terminada ao fim de sete anos, podendo ser prorrogada em circunstâncias especiais.

De acordo com Ferreira (2005), já em 1871, o coronel Church, intermediado por banqueiros ingleses, contrata a empresa inglesa "Public Works" para executar a construção da ferrovia. O empréstimo efetuado na praça londrina, bem como seus juros, teriam o governo boliviano como garantidor (cerca de 700.000 libras esterlinas). Foi acordado ainda que a "Public Works" iria receber pagamento da "Madeira and Mamoré Railway Co." na medida em que a estrada fosse sendo construída.

No dia 6 de julho de 1872, um grupo formado por 25 engenheiros da "Public Works" chega a Santo Antônio. As precárias condições de trabalho e de sobrevivência em plena selva amazônica, aliado às inúmeras mortes de trabalhadores e aos constantes ataques de tribos indígenas fizeram os prejuízos da "Public Works" aumentar consideravelmente. Assim, dez meses 
depois de começar o trabalho, a empresa de engenharia inglesa resolveu sair da área e abandonar o empreendimento. No dia 9 de julho de 1873, sem ter assentado nenhum metro de trilho, a "Public Works" decide romper o contrato de construção da estrada de ferro e ainda reclamaria o recebimento de uma indenização pelos prejuízos que sofrera.

O coronel George Earl Church, em 17 de setembro de 1873, firmou um novo contrato para a construção da ferrovia, agora, com a empresa estadunidense Dorsay \& Caldwell. Em 24 de janeiro de 1874, a empresa envia para o local uma equipe composta por um engenheiro e dez trabalhadores braçais. Depois de alguns dias e uma morte, a comitiva voltou para os Estados Unidos e, apesar de possuir o contrato da empreitada, desistiu de construir a estrada de ferro por absoluta falta de condições técnicas e sanitárias.

A Dorsay \& Caldwell repassou, em 25 de agosto de 1875, o contrato de concessão da estrada de ferro para a empresa inglesa Reed Bros \& Co. Interessante observar que essa empresa desconhecia a região e o projeto a ser executado e começou a protelar o assunto, aumentando as exigências contratuais para atuar em lugar tão distante. $\mathrm{O}$ coronel Church declarou nulo o contrato. Mesmo assim, a Reed Bross \& Co exigiu e recebeu de Church uma indenização de vinte e cinco mil libras esterlinas, por perdas e danos que, na verdade, não existiram.

No dia 25 de outubro de 1877 a Madeira and Mamoré Railway Co. firma um contrato com a empreiteira estadunidense P \& T Collins, para a construção de 320 quilômetros de trilhos da Madeira-Mamoré, com preço estipulado de um milhão e duzentas mil libras esterlinas. A $P$ \& $T$ Collins deveria iniciar os trabalhos em Santo Antônio antes do dia 25 de fevereiro de 1878 e deveria terminar a construção ao fim de três anos.

O serviço não avançava. Deserções de trabalhadores, doenças tropicais que atacavam indiscriminadamente, chuvas intermitentes e a escassez de víveres tornavam o processo de construção extremamente lento. Eram assentados uma média de 700 metros de trilhos por mês, contra os dez quilômetros por mês, estabelecidos em contrato.

O problema da $\mathrm{P} \& \mathrm{~T}$ Collins se agravou quando a Madeira and Mamoré Railway Co. não honrou pagamentos à empreiteira que, àquela altura, estava sem créditos nas praças de Belém, Manaus e mesmo nos Estados Unidos. 
As defecções entre os operários não paravam. No dia 19 de agosto de 1878, o contrato de trabalho por seis meses terminou para a grande maioria dos trabalhadores. Mesmo sem dinheiro, cerca de 300 operários partiram para Belém do Pará, na esperança de voltarem para os Estados Unidos. Famintos e esgotados, esmolaram por algum tempo nas ruas daquela cidade até serem reenviados para seu país de origem.

No dia 19 de agosto de 1879, estava oficialmente suspensa a construção da ferrovia por parte da $P$ \& $T$ Collins. Todos os materiais foram abandonados. Em um ano e meio de trabalho, a empresa conseguiu assentar apenas sete quilômetros de trilhos. A firma $P$ \& $T$ Collins entrou em processo de falência, ficando sem receber nada por todas as atividades executadas naquele período.

Posteriormente ao último fracasso, o coronel Church abandonou definitivamente seus planos de construção da estrada de ferro MadeiraMamoré e, em 1881, o governo imperial brasileiro decreta a extinção da concessão dada ao coronel Church para a empreitada.

Ainda conforme Ferreira (2005), em 15 de maio de 1882 os governos de Brasil e Bolívia firmaram um tratado sobre navegação dos rios dos dois países, além da retomada da construção da Estrada de Ferro Madeira-Mamoré, que a Bolívia poderia utilizar, bem como o livre trânsito de suas importações e de suas exportações. Essa pagaria apenas o frete estabelecido pela empresa operadora da futura ferrovia, ficando isenta de tributação brasileira em seu comércio exterior. De acordo com Tocantins, o governo boliviano "projeta iniciar entre La Paz e Yungos uma via intercontinental, pela qual se poderá atravessar de Belém do Pará à Antofagasta, no Chile, ou a Molendo, no Peru, isto é, do Atlântico ao Pacífico, em barcos a vapor ou em caminho de ferro." (TOCANTINS, 1979, v. 2, p. 297)

Em outubro do mesmo ano, o governo imperial brasileiro cria uma comissão para estudar o traçado da futura estrada de ferro. A comissão, capitaneada pelos engenheiros Carlos Alberto Morsing e Júlio Pinkas, diverge no que tange ao traçado, mas não sobre a necessidade da ferrovia. Mesmo com o trabalho da comissão, o governo imperial brasileiro não levou a construção da ferrovia adiante. 
Já no período republicano, uma efêmera tentativa de construção ocorreu com a entrega de uma concessão, em 30 de maio de 1891, aos senhores José Eulálio da Silva e Francisco Mendes da Rocha, para a construção da ferrovia que, ao invés de ser construída em seu trajeto pré-estabelecido (de Porto Velho ou Santo Antônio até Guajará Mirim, num trajeto de aproximadamente $362 \mathrm{~km}$ ), estendia a ferrovia desde a cidade amazonense de Humaitá até a confluência dos rios Mamoré e Guaporé. O projeto não saiu do papel e, dois anos depois, a concessão expirou.

Nesse período, a Bolívia contava com duas ferrovias ligando seu território ao oceano Pacífico. A Ferrovia Antofagasta-Bolívia, de propriedade da firma inglesa The Antofagasta and Bolivia Railway Company Limited, finalizada em 1892, fazia a ligação entre Antofagasta e se dirigia à cidade de Uyuni, no departamento de Potosi, de onde partiam dois ramais, um para a cidade de Oruro e outro para Huanchaca, também em Potosi. Já a Ferrocarril del Sur del Peru ligava o porto de Molendo à cidade de Juliaca, onde entroncava com a linha que seguia para Puno, todas no Peru (Mapa 6). Para alcançá-la era necessário ou cruzar pelo lago Titicaca, cuja navegação também era controlada pela Ferrocarril del Sur del Peru, ou contorná-lo por uma estrada de rodagem, a partir da cidade boliviana de Guaqui. Em 1906, tem início a construção de um ramal ferroviário ligando a cidade de Guaqui à La Paz, para integrá-la à rede ferroviária peruana, financiada pelo governo daquele país para controlar as rotas comerciais do sul do Peru, fazendo frente ao domínio chileno sobre as rotas comerciais da Bolívia. Essa ferrovia estava ligada à necessidade de transportarem produtos minerais das áreas produtoras para abastecerem os mercados dos Estados Unidos e da Europa. No entanto, mesmo com essas duas alternativas, a saída pelo Atlântico era mais racional, principalmente no que tange ao tempo de viagem.

Nesse sentido, para Ferreira (2005), a Argentina levava vantagem, pois o acesso ao oceano Atlântico pelo Brasil encontrava sérias dificuldades para transporem-se as regiões de cachoeiras do Madeira, já que, apesar de todos os esforços, a ferrovia ainda não havia sido construída. Pela Argentina, os trilhos já chegavam às cidades nortistas de Jujuy e Oran, e a ligação ferroviária entre a cidade argentina de La Quiaca e a boliviana Tupiza, segundo Ferreira (2007), concluída em 1915, possibilitava o acesso ao porto de Buenos Aires. O 
escoamento se tornava mais prático, uma vez que a planície e a vegetação não ofereciam grandes obstáculos à expansão dos trilhos ferroviários até o território boliviano. Vale lembrar a possibilidade de uso, por parte da Bolívia, de um sistema hidroviário ligando o rio Pilcomayo e duas rodovias até o porto Vargas e o porto Pacheco, ambos no rio Paraguai.

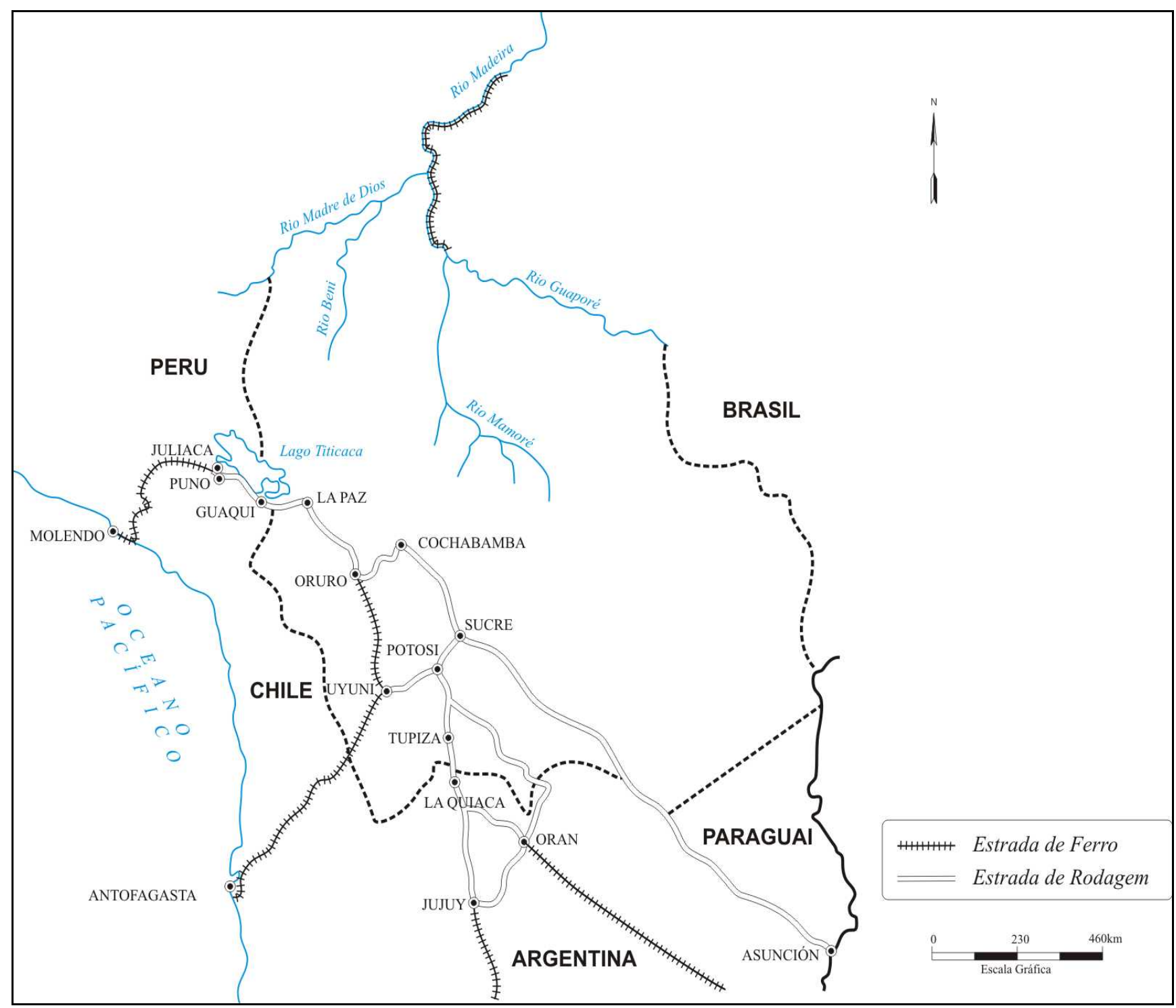

Mapa 6

Ferrovias da Bolívia no final do século XIX, (FERREIRA, 2005, p. 185 - adaptado) 
Vê-se, portanto, que a presença de duas linhas férreas, uma no Chile e outra no Peru, além da possibilidade da circulação mercantil dos produtos bolivianos pelas ferrovias argentinas, e da possível utilização do meio fluvial, a importância da ferrovia Madeira-Mamoré diminuía a cada dia.

Um fato novo, porém, despontava no cenário do sudoeste da Amazônia, a partir da segunda metade do século XIX. Novos processos produtivos relacionados à Segunda Revolução Industrial passaram a aproveitar de maneira crescente a borracha, seja para a produção de pneus, seja na fabricação de correias para máquinas e outros artefatos industriais. O látex, matéria-prima da borracha, naquela época, apenas era encontrado na parte sudoeste da floresta equatorial amazônica, dividida entre a República da Bolívia e o Império brasileiro.

Garcia (2009) relata que o boliviano Adolpho Ballivian possuía concessões para a exploração de meios de transporte no Mato Grosso, no Brasil, desde 1895. Ballivian deveria construir uma estrada de rodagem, posteriormente substituída em contrato por uma ferrovia, justamente entre Santo Antônio e Guajará Mirim. Não conseguindo cumprir o contrato em questão, Ballivian vendeu a concessão para a firma Syndicate de la Banque Africaine, de origem belga, que tinha por objetivo a operação na fronteira oeste do Brasil e na Amazônia. A concessão caducou. Nesse mesmo período, o Syndicate de la Banque Africaine "estava em negociações com o governo da Bolívia para a construção de um porto na margem esquerda do rio Paraguai, na região da Bahia Negra. Por esse contrato, o porto seria ligado por uma ferrovia a Santa Cruz de La Sierra, com ramais para Potosi e Sucre." (GARCIA, 2009, p. 142)

Azevedo (s.d.) afirma que o Syndicate de la Banque Africaine também possuía a concessão do governo boliviano para a construção, em 1891, da ferrovia para Antofagasta.

Esses projetos não saíram do papel pelas mãos da Africaine, mas serve para demonstrar a penetração do capital belga no coração da América do Sul, não só com esses empreendimentos, mas também abrindo pelo menos cinco empresas de caráter colonial no Brasil e da compra, por uma dessas empresas, da fábrica de extrato de carne Compagnie des Produits Cibils, situada em uma área quase contínua, de cerca de um milhão e quinhentos mil 
hectares em Descalvados, no Mato Grosso, fronteira com a Bolívia. Além disso, os belgas dirigiram investimentos na exploração de três áreas para extração da borracha, no vale do rio Guaporé. Tal situação foi objeto de estudo de doutorado de Domingos Sávio da Cunha Garcia.

O interesse belga pela área durou até 1904, quando a situação apontava para o fracasso do conjunto dos negócios dos belgos na região, uma vez que outra empresa de caráter colonial, a Bolivian Syndicate não conseguiu executar sua proposta colonialista na área, como observamos anteriormente. A partir de 1912, os belgas começam a vender seus empreendimentos no Brasil, sendo que a fábrica de extrato de carnes e as concessões de exploração da borracha foram vendidas para o conglomerado do lendário empresário estadunidense Percival Farquhar, que passou a controlar a produção da borracha no vale do rio Guaporé, sua comercialização e transporte, como será discutido adiante.

Com a assinatura do Tratado de Petrópolis, em 17 de novembro de 1903, o Brasil toma como tarefa obrigatória a construção da ferrovia que suplantará o trecho encachoeirado dos rios Madeira e Mamoré, tanto que, já em março de 1904, o gabinete da Presidência da República brasileira determina o cumprimento integral e imediato do que foi acordado no Tratado de Petrópolis. Para tanto, em 12 de maio de 1905, o governo brasileiro publica um edital de concorrência pública para a construção da ferrovia em questão.

A concorrência é vencida pelo engenheiro brasileiro Joaquim Catrambi. Em seguida, este vende a concessão de construção para Percival Farquhar, proprietário de vários empreendimentos, tanto no exterior quanto no Brasil. Ele contrata a empresa May \& Jekyll que já prestava serviços a Farquhar na América Central, para a construção da Madeira-Mamoré, esta de propriedade do Estado brasileiro. Foram empregados cerca de trinta mil trabalhadores oriundos de várias partes do mundo, dos quais aproximadamente seis mil faleceram no local.

Em 1907, tem início a construção da ferrovia, cujo ponto inicial seria a localidade de Ponto Velho, hoje Porto Velho, atual capital do Estado de Rondônia. Nesse mesmo ano, no dia 2 de agosto, Percival Farquhar funda nos Estados Unidos a Madeira-Mamoré Railway e, imediatamente, formaliza a compra da concessão da construção da ferrovia Madeira-Mamoré de Joaquim Catambri e nomeia Alexandre Mackenzie como seu representante no Brasil. 
O governo brasileiro, em 1909, arrenda a estrada de ferro à MadeiraMamoré Railway. O início de arrendamento é marcado para 1912, tendo validade por sessenta anos. Interessante lembrar que uma das cláusulas do contrato dizia que a empresa permissionária não poderia, a não ser por força maior ou por vontade do governo, paralisar as atividades ferroviárias.

No dia primeiro de agosto de 1912 é inaugurada a Estrada de Ferro Madeira-Mamoré, ligando Porto Velho, até então distrito da cidade de Humaitá, estado do Amazonas, à cidade de Guajará Mirim, numa extensão de 364 quilômetros. Em 1923, ela ganhou um pequeno acréscimo em sua extensão, ficando, então, com 366 quilômetros e 485 metros.

Desde o início de sua operação, no entanto, a estrada se mostrou deficitária. Grande parte da mercadoria transportada era composta de borracha, que começava a perder valor no mercado internacional ${ }^{18}$, graças à concorrência dos seringais localizados no sudeste asiático. Vale mencionar que a seringueira é originária da flora amazônica, porém, de acordo com Ferreira (2005), “Em 1876, o cidadão inglês Henry Wickham, coletou, no Amazonas, 70.000 sementes de Hervea, que levou para o jardim botânico de Kew, na Inglaterra. Convenientemente plantadas e tratadas, duas semanas após a chegada daquelas sementes a Londres, germinaram cerca de 2.700. Estas plantas foram transportadas para a Ilha de Ceilão, de onde se espalharam por todo o oriente." (FERREIRA, 2005, p. 187) Longe dos parasitas e dos predadores da Amazônia, não existentes naquela região, com a presença de mão-de-obra farta, aliada à facilidade relativa de retirada do látex, já que os trabalhadores não precisavam percorrer enormes distâncias para extrair o produto, pois as árvores foram plantadas umas próximas das outras, seu sucesso foi enorme.

Para compensar o enorme gasto com a construção da ferrovia, o preço do frete era muito alto, desencorajando a utilização desse meio de transporte pelos produtores de borracha, já prejudicados pela diminuição dos pedidos de seus produtos. Mesmo o oriente boliviano quase não era beneficiado pela ferrovia, devido às imensas dificuldades de transporte em função da falta de

\footnotetext{
18 "O preço da borracha atingiu a sua cotação mais alta no ano de 1910, correspondendo a 655 libras esterlinas a tonelada. No ano da República era de 200 libras esterlinas a tonelada. No ano de 1930 chegou à sua baixa máxima, 32 libras/tonelada". (MATTOS, 1980, p. 49)
} 
redes de comunicação entre aquela região e a de Madeira-Mamoré, pois "a Bolívia, maior interessada, não construiu rodovias ligando o Departamento de Beni, principalmente a cidade de Guayaramirim, com os centros mais importantes do país, como Santa Cruz de La Sierra e La Paz, o que deixou a estação terminal Mamoré completamente isolada." (FERREIRA, 2007, p. 78) Também não saiu do papel a ferrovia que ligaria La Paz à Puerto Beni, o que reforçaria a importância da Madeira-Mamoré e a possível ligação entre os oceanos Pacífico e Atlântico, tendo a ferrovia como elo.

Vale lembrar que, além do declínio no comércio da borracha amazônica, que, ironicamente, teve início quando da inauguração da ferrovia, a Bolívia poderia contar com o uso, a partir de 1914, do recém construído Canal do Panamá, que começou a fazer a ligação marítima entre o Pacífico e o Atlântico na América Central continental ou ainda dispor do porto de Arica no Chile, valendo-se da então novíssima ferrovia Arica-La Paz, cuja construção terminou em 1913. E ainda paira a ameaça da Estrada de Ferro Central Argentina que, a passos acelerados, atrai o mercado da cidade boliviana de Cochabamba, direcionando-o para o porto de Buenos Aires.

A estrada de ferro Madeira-Mamoré estava umbilicalmente ligada ao escoamento da borracha. As exportações brasileiras e bolivianas do produto caíram vertiginosamente a partir de 1913. A concessionária da ferrovia não podia diminuir o valor do frete em face dos altos custos derivados da manutenção da ferrovia. O impasse estava criado.

Após uma tentativa de bloqueio e destruição de partes da ferrovia, uma tarifa emergencial e transitória foi aprovada e posta em prática pela concessionária da ferrovia, porém, sem surtir muitos efeitos práticos, uma vez que a rota em questão já estava com o seu funcionamento comprometido pela escassez de produtos a serem transportados.

A agonia da concessionária Madeira-Mamoré Railway se estendeu até o ano de 1934, quando o governo de Getúlio Vargas rescindiu o contrato de concessão da ferrovia.

Uma possível solução para a ferrovia Madeira-Mamoré poderia estar na proposta de Travassos (1935), que propôs a ligação dessa ferrovia com o oriente boliviano. Travassos estava preocupado em atrair o oriente boliviano para a órbita brasileira. Para tanto, não bastava apenas a atração pelo leste 
daquele país via ferrovia Brasil-Bolívia e a ligação com a Noroeste. Seria também necessário atrair o oriente boliviano pelo norte,

que se manifesta pela Madeira-Mamoré captando os transportes pelo Rio Grande, francamente navegável desde Cuatro Oyos $(200$ km. abaixo de Santa Cruz, dos quais 100 já abertos em rodovia) e podendo ser dobrada por transportes rodoviários, quando se ligarem Portachuelo-Cuatro OyosTrinidad-Santana-Exaltacion (centros dos mais florescentes) a Santa Cruz e Guajará-Mirim. Ao nosso ver a atração norte será a decisiva. Serve a $3 / 5$ do território boliviano, se encararmos o vale do Beni como sua variante. (TRAVASSOS, 1935, pp. 8687)

Dessa forma, desestimularia a atração que a bacia platina exercia sobre a Bolívia e estimularia a atração pela bacia amazônica, porém as medidas propostas por Travassos para o norte da Bolívia não aconteceram.

Em 1966, o governo federal transfere a Madeira-Mamoré para o Ministério da Guerra, para que este substituísse a ferrovia por uma rodovia.

No dia 10 de julho de 1972 encerravam-se as atividades da Estrada de Ferro Madeira-Mamoré (Foto 2). O "espetáculo privilegiado da civilização capitalista na selva" (HARDMAN, 2005, p. 25), não conseguiu servir de escoadouro da produção boliviana pelo porto de Belém do Pará, no oceano Atlântico. A opção boliviana por caminhos mais rápidos, seguros e, principalmente, mais baratos de transporte de mercadorias foi um dos principais fatores do declínio da Madeira-Mamoré.

A necessidade da ferrovia Madeira-Mamoré esteve vivamente presente na segunda metade do século XIX, já que as técnicas até então existentes no ramo dos transportes não satisfaziam a necessidade comercial do Estado boliviano de inserção no mercado mundial, principalmente o acesso aos portos do Pacífico, pois a íngreme e abrupta escarpa terciária andina praticamente inviabilizava o transporte de cargas para esse litoral. 


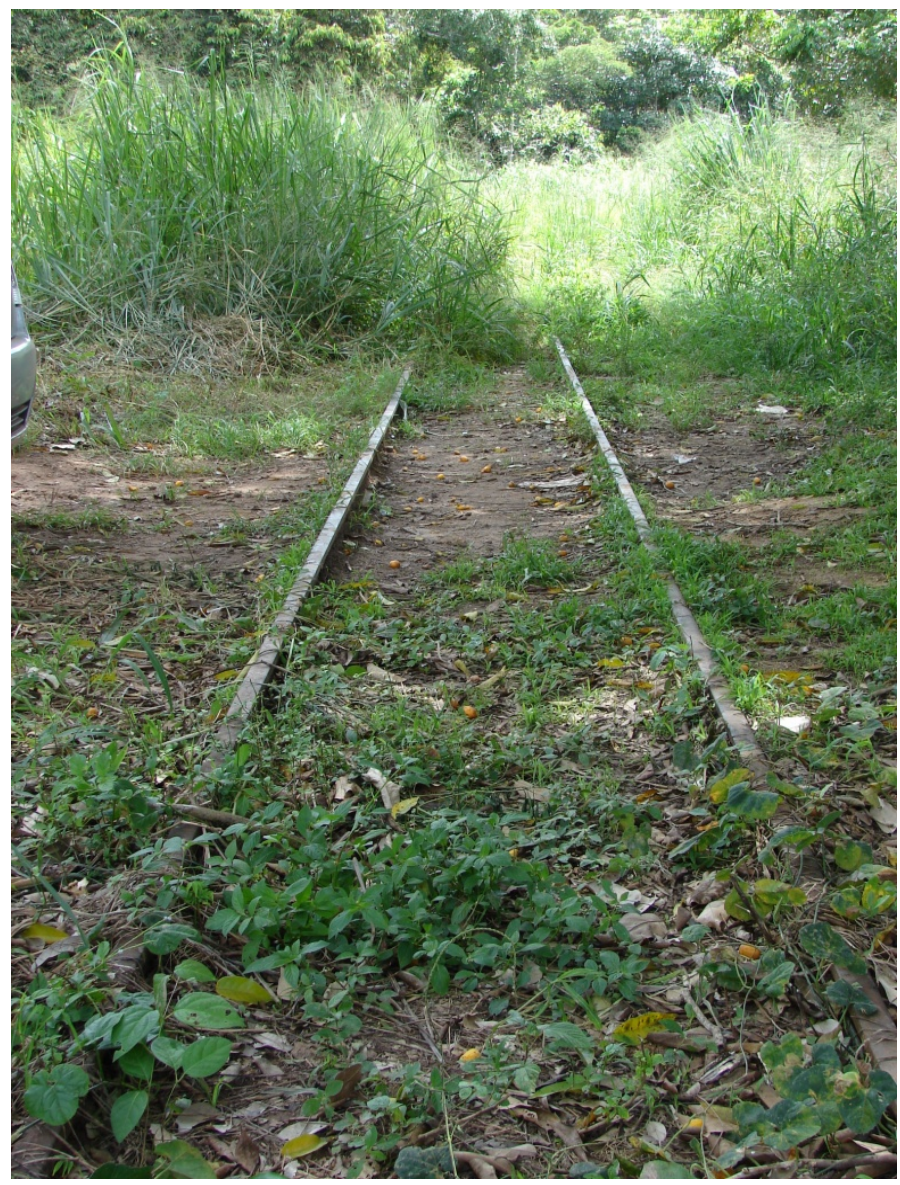

Foto 2 - Restos dos trilhos da ferrovia MadeiraMamoré, desativada em 1972.

(Fonte: Maria Keiko Yamauchi, em 28 fev 2008).

Porém, com o passar dos anos e o aumento vertiginoso da técnica empregada nos meios de transporte, a ideia revolucionária de uma ferrovia cortando a selva dá lugar a novos ciclos da racionalidade técnica capitalista que, a partir do início do século XX, desenvolve outras formas mais funcionais para a circulação de mercadorias, que também pode ser escoadas por outras formas ainda mais modernas.

\subsection{A GUERRA DO CHACO}

Foi na Guerra do Chaco (1932 - 1935), deflagrada contra o Paraguai, que a Bolívia conheceu uma de suas piores derrotas internacionais. De acordo com Andrade (2007), na disputa por essa inóspita e despovoada área, a Bolívia perdeu aproximadamente $240.000 \mathrm{~km}^{2}$ de sua área para o Paraguai. 
"Una lucha tribal con elementos modernos". (MERCADO, 1967, p. 37) Nas letras desse autor, uma luta entre dois países que, no século XIX, foram as maiores vítimas do comércio inglês na América Latina.

De acordo com Lewis (2008), em 1930 apenas 19 pessoas eram donas da metade das terras do Chaco, principalmente investidores estrangeiros, dentre eles, vale destacar a família Casado, da Argentina, proprietária de extensas terras no Chaco destinadas à pecuária e a empresa estadunidense International Products, proprietária de uma fábrica de embalagem de carne, além de atuar na exportação de couro e de carne salgada.

Tanto Doratioto (1994) quanto Lewis (2008) entendem que, para a Bolívia, a necessidade da posse do território do Chaco era fundamental, em função da perda do seu litoral para o Chile, na Guerra do Pacífico. A planície do Chaco permitiria acesso ao rio Paraguai e daí ao rio da Prata e, por conseguinte, ao Oceano Atlântico.

O Paraguai alegava que a Bolívia lentamente expandia sua linha de fronteira no Chaco utilizando para isso a construção de fortificações militares. A estratégia utilizada pelos bolivianos era esperar alguma reclamação do governo paraguaio e resolver a questão por intermédio de uma conferência diplomática, como aconteceu em 1907 e 1913, pois como o governo boliviano sabia das limitações militares do Paraguai, sempre conseguia avançar sobre o território paraguaio.

Bieber (2000) salienta que o Chaco possuía imprecisão fronteiriça entre a Bolívia e o Paraguai, pois desde a época colonial a área em questão nunca despertou qualquer interesse por parte dos espanhóis. A tentativa de delimitação fronteiriça entre a Bolívia e o Paraguai levou a pequenos confrontos entre os dois países, como em 1927, porém, mesmo com a mediação da Argentina, não chegaram a um acordo.

Lewis (2008) escreve que, no final de 1928, a Bolívia avançou até a montante do rio Paraguai, construindo um forte denominado Fortín Vanguardia. Essa fortificação, segundo Bieber (2000), foi atacada por um destacamento do exército paraguaio que buscava ocupar a região por intermédio de colonizações agrícolas. A resposta boliviana veio com a tomada dos fortes paraguaios Corrales e Toledo. As relações diplomáticas entre os dois países foram rompidas. 
Os dois países aceitaram a mediação da Conferência Pan-Americana de Conciliação e Arbitragem que, segundo Doratioto (1994), propôs a soberania do Paraguai no Chaco Boreal e concedia à Bolívia o porto da Baía Negra. Tal solução foi rejeitada por ambos os países. No início de 1929, porém, os dois países assinaram um Ato de Conciliação, pois não era interessante um conflito armado entre os países vizinhos. No caso da Bolívia, o então presidente Hernando Siles Reyes estava ciente tanto da grave crise econômica pela qual a Bolívia passava, quanto pela sua da falta de recursos, materiais e humanos, das forças armadas bolivianas. O presidente paraguaio José Patrício Gugguari sabia que seu país, naquele momento, não estava preparado para um conflito armado.

A economia boliviana entrou em um forte processo de deterioração, impactada essencialmente pelos efeitos da crise econômica de 1929. O estanho era o principal produto de exportação do país. Para entendermos a importância desse produto, Contreras escreve que "entre 1900 e 1929, as exportações de estanho cresceram cinco vezes, e a participação da Bolívia na produção mundial mais do que dobrou, sendo responsável, de 1918 a 1929, por quase um quarto da produção mundial" (CONTRERAS apud THORP, 2005, p. 118) Em 1928 o preço do estanho chegou a ser cotado em 225 libras a tonelada.

Em função da crise econômica do capitalismo, o preço do estanho despencou para 118 libras em 1931. Em 1932, o principal grupo mineiro boliviano (Grupo Patiño) reduziu seu quadro de funcionários de 7.000 empregados para apenas 2.000. Nas palavras de Gumucio "el resfrío del Tío Sam equivalía en el sur a uma pulmonía"19. (GUMUCIO, 1996, p. 39) Ayerbe (2002) afirma que a crise do capitalismo abalou violentamente a frágil economia boliviana, pois, apesar da elite estanhífera praticamente não pagar impostos, a mineração participava com $40 \%$ do Produto Interno Bruto da Bolívia.

Hernando Siles Reyes foi deposto em maio de 1930 por Carlos Blanco Galindo, representante da elite estanhífera. Em março de 1931, Daniel Salamanca Urey, representante da oligarquia e do capital internacional, assume

\footnotetext{
${ }^{19}$ Tradução livre: O resfriado do tio Sam equivalia no sul a uma pneumonia.
} 
a presidência da Bolívia, via eleitoral, substituindo Carlos Blanco Galindo. Este se deparou com a queda acentuada na arrecadação de tributos e com o aumento do índice de inflação. Nas ruas, as greves e movimentos de estudantes aumentavam, exigindo melhoria das condições de vida. O governo Salamanca respondia às manifestações com forte repressão, fechamento de sindicatos e prisões de líderes.

No dia primeiro de julho de 1931, o presidente Daniel Salamanca voltou a romper relações diplomáticas com o Paraguai, depois de um pequeno desentendimento sobre a posse de uma laguna na fronteira entre os dois países. No final do mesmo mês e ano, a Bolívia deixa de efetuar o pagamento de sua dívida externa que, nesse período, era aproximadamente 70 milhões de dólares. Para completar o difícil quadro econômico, a produção de estanho é paralisada, seguindo instruções do Comitê Internacional dos Grandes Produtores de Estanho.

A partir desse momento, o governo da Bolívia emprega toda a sua energia na preparação de uma ocupação militar no Chaco. É a maneira que o governo boliviano encontra para desviar a atenção popular das mazelas da combalida economia boliviana e buscar a chamada união nacional, dessa forma, garantindo ainda em suas mãos o governo do Estado, ou seja, a ameaça de um possível domínio estrangeiro é usada como um importante fator para tentar promover a solidariedade nacional e legitimar o governo.

Klein enfatiza que Daniel Salamanca, "nos difíceis dias de 1932, voltou suas energias para o Chaco. No seu entender, era uma questão com que ele podia lidar, pois confiava que a nação o acompanharia onde quer que ele a levasse e tinha certeza de que os liberais e os radicais não podiam obstar seu campo de ação." (KLEIN, 2008, p. 409)

Tendo o sentimento do apoio incondicional do povo boliviano e a certeza de que o agravamento da crise econômica traria consequências nefastas para a Bolívia, Salamanca ignora o parecer contrário de seu staff militar e sequer parte para uma negociação formal com o Paraguai. No final de julho de 1932, o governo boliviano dá início à guerra contra o país vizinho.

Andrade (2007) salienta que quando a guerra se iniciou, o exército boliviano, formado principalmente por índios e mestiços pobres, começou a enfrentar grandes dificuldades. Os soldados bolivianos eram em sua maioria 
acostumados a viver nas terras frias, secas e de pouco ar do Altiplano Andino. Sem treinamento para lutar numa terra avara, eles foram obrigados a lutar numa região inóspita, seca e arenosa. As áreas onde começaram os combates eram hostis e distantes das principais cidades bolivianas e não existiam estradas. Além disso, era difícil chegar água e alimentos para os soldados, que sucumbiam perante o calor e a sede.

Andrade (2007) reforça que, nessas condições do exército boliviano, desde cedo os paraguaios superaram em capacidade militar o exército inimigo. Ao contrário dos bolivianos, os paraguaios, mesmo em número inferior, viviam e conheciam melhor a região e estavam mais próximos de suas cidades e de seus pontos de abastecimento. Assim, ficaram numa situação mais vantajosa que a dos bolivianos para a luta. O que o governo boliviano esperava que fosse uma rápida guerra de conquista, tornou-se um pesadelo. Milhares de soldados morreram de sede e de fome, suportando um calor exacerbado, que beirava os $40^{\circ} \mathrm{C}$ durante o dia, a centenas de quilômetros dos principais centros econômicos da Bolívia. A situação tornava-se cada vez mais desesperadora para as forças militares do altiplano.

Segundo Gumucio (1996), o exército boliviano, com muitas baixas e moralmente abatido, foi perdendo a maioria das batalhas em que se envolvia. O vice-presidente liberal José Luis Tejada Sorzano, que assume o poder a pedido dos militares golpistas, tenta uma reação, concentrando em Villa Montes o que restou do exército boliviano, junto com os novos convocados. Uma nova derrota, porém, fez com que o Tejada Sorzano aceitasse uma mediação para por fim ao conflito.

Andrade afirma que

Em 25 de novembro de 1934, o presidente Daniel Salamanca foi deposto por oficiais do exército em pleno desenvolvimento das operações militares, quando tentava mais uma vez trocar a chefia do alto comando. O governo foi entregue ao vicepresidente Tejada Sorzano que tratou de imediatamente iniciar conversações e assinar a paz com o Paraguai em 14 de junho de 1935. A Bolívia terminava o conflito deixando mais de 65.000 soldados mortos, pelo menos 240 mil quilômetros 
quadrados de território para o Paraguai e a economia nacional destroçada. (ANDRADE, 2007, p. 32)

Em maio de 1936, o coronel José David Toro Ruilova chega à presidência. Gumucio (1996) afirma que, a partir dessa data, se inicia a era dos generais ditos "socialistas". Essa alcunha foi dada em função do anseio de trocar o poder da oligarquia mineira por um governo que começasse a atender os despossuídos.

Seu governo foi composto por algumas pessoas da esquerda e com pitadas do movimento fascista, que estava no auge na Europa. No entanto, o poder econômico da elite mineira e dos fazendeiros se manteve intacto. $\mathrm{Na}$ verdade, o termo "socialista" utilizado pelos militares no poder não passava de uma fachada para reformar e modernizar o capitalismo na Bolívia. Tanto é que, no final de 1936, o governo Toro proibiu a atividade de entidades e partidos políticos com viés marxista e anarquista, além de destruir livros e documentos dessas teorias. Além disso, o governo Toro contratou uma missão italiana para reorganizar a polícia militar boliviana. Nos dizeres de Gumucio (1996), a presença da delegação italiana inspirou um grupo de estudantes universitários a criar o partido fascista Falange Socialista Boliviana, formado fundamentalmente por filhos da elite e da classe média católica, que se vestiam com camisas brancas, dotados de um discurso moralista, repudiando tanto o liberalismo quanto o comunismo.

O principal feito do governo Toro foi a nacionalização da companhia de petróleo estadunidense Standard Oil, por meio do Decreto Supremo, promulgado em 13 de março de 1937,

promovendo a anulação das concessões e o confisco dos bens da empresa norte-americana Standard Oil, acusada de violação ao contrato de concessão e traição à pátria durante a Guerra do Chaco (1932-1935). Após intensa pressão do governo dos EUA - que suspendeu a ajuda econômica à Bolívia -, e longas tratativas diplomáticas, um acordo foi concluído em janeiro de 1942, pelo qual se pagou à Standard Oil uma indenização de US\$ 1,7 milhões. O breve governo de David Toro ainda criara, em 1936, a Yacimientos Petrolíferos Fiscales Bolivianos 
(YPFB), a qual ficou responsável pela continuidade da produção nas instalações confiscadas da Standard Oil. A legislação então permitia a associação da YPFB com empresas privadas e não the assegurava o monopólio, prevendo a possibilidade de concessão a qualquer outra companhia. (ALEXANDRE, 2006, p. 16)

\subsubsection{A QUESTÃo DO PETRÓLEO}

Assim como na Guerra do Pacífico, entra em discussão se a Guerra do Chaco teve interesses imperialistas, haja vista que na área em disputa foram descobertas algumas jazidas de petróleo e a posse dessas jazidas motivou o desencadeamento da guerra. Eram, portanto, as disputas entre as empresas pretrolíferas o motivo do conflito. Klein (2008) revela que, em virtude da incapacidade dos empresários bolivianos em extrair petróleo do subsolo boliviano, o governo resolveu passar à Standard Oil Company of New Jersey (atual Exxon), em 1921, a concessão de exploração, fundando a Standard Oil Company of Bolivia.

Seguindo esta linha de raciocínio estão Omar Díaz Arce e Júlio José Chiavenato. Para esses autores, a Standard Oil Company of New Jersey, representando o imperialismo estadunidense, insuflou a Bolívia. A Royal Dutch Shell, representando o imperialismo inglês, aliou-se à Argentina, que dominava o Paraguai. Ambos armaram e empurraram o Paraguai para a guerra. "Não se pode explorar o petróleo sem controlar os governos dos respectivos países onde se vai buscá-lo." (CHIAVENATO, 1979, p. 106)

De acordo com os autores acima citados, a Standard Oil pretendia construir um gasoduto, que cortaria o território paraguaio, para a exportação de seu petróleo explorado em território boliviano, porém, o Paraguai negou-Ihes a licença de construção do gasoduto, atendendo aos interesses da Royal Dutch Shell que, por sua vez, queria apoderar-se dos poços bolivianos.

Para corroborar com essa tese, Chiavenato cita uma afirmação de Libório Justo, filho do então presidente Justo, da Argentina: 
Na Bolívia, onde domina o capital norte-americano, a Standard Oil necessitava de uma saída para o rio Paraguai para seus poços de petróleo no leste daquele país. Por trás do Paraguai, a companhia inglesa Royal Dutch tratou de evitá-lo. Essa foi a causa do conflito que tem ensanguentado o continente. (ibidem, p. 108)

Ainda segundo Chiavenato,

Aí está a raiz da guerra: os trustes petrolíferos jogam com argumentos e intrigas que envolvem cada uma das duas companhias, apresentando a rival como vilão da história. A Royal Dutch Shell - de quem a Argentina é indisfarçável aliada e o Paraguai um passivo instrumento - fomenta as acusações pela imprensa e nos meios diplomáticos, afirmando que a Standard Oil quer um oleoduto para exportação e, para consegui-lo, está armando a Bolívia para uma guerra de conquista de territórios paraguaios no Chaco, por onde passaria esse oleoduto. A Standard Oil, da mesma forma, alimenta as intrigas de que a Royal Dutch Shell, aliada dos interesses argentinos, pretende tomar vastas regiões do Chaco, chegar ao sopé dos Andes e apossar-se das áreas petrolíferas bolivianas, que passariam a pertencer à Argentina $\mathrm{e}$ seriam exploradas pela Shell. (ibidem, p. 108)

Chiavenato (1979) cita o senador estadunidense Huey Pierce Long que, em maio 1934, denunciou ao congresso dos Estados Unidos da América que um empréstimo realizado à Bolívia em 1928, denominado Dillon Reed ${ }^{20}$, no valor de 23 milhões de dólares, só se tornou possível graças ao aval da Standard Oil. A maior parte do dinheiro deveria seguir para a construção das ferrovias La Paz-Beni e Santa Cruz de la Sierra-Cochabamba. Chiavenato (1979) afirma que esse dinheiro foi dirigido para a compra de material bélico

\footnotetext{
${ }^{20}$ De acordo com Gumucio (1996) esse empréstimo estava vinculado a visita da chamada Missão Kemmerer que, além de outras medidas, criou o Banco Central Boliviano e o Instituto Central da Moeda, além de privatizar os correios e telégrafos, que foram entregues à estadunidense Marconi. O trecho boliviano da ferrovia Arica-La Paz foi adquirido por um grupo privado boliviano.
} 
para ser usado na guerra contra o Paraguai. Pouco tempo depois, em 10 de setembro de 1935, o senador Huey Pierce Long foi assassinado a tiros em frente ao congresso em Washington.

A nacionalização da Standard Oil, em março de 1937, é encarada por Chiavenato (1979) como uma represália por parte do governo boliviano, pois essa empresa recusou-se a emprestar mais dinheiro para a guerra, já em seus estertores, com um discurso de que as riquezas do país devem ficar em benefício da Bolívia e não de uma companhia estrangeira.

Zavaleta Mercado (1967), por outro lado, sustenta que, apesar de a Argentina apoiar o Paraguai com alimentos, armas e munições e a Royal Dutch Shell ter bastante interesse na Argentina, os interesses comerciais eram bem maiores que os desentendimentos fronteiriços, pois a Standard Oil, a partir de seus campos na Bolívia, exportava petróleo, utilizando um oleoduto clandestino que chegava à Argentina. Portanto, se a Standard Oil realmente tivesse interesse na vitória da Bolívia, minaria qualquer tentativa de compra de seus produtos por parte de um país que apoiava o inimigo Paraguai. Quando o governo boliviano descobre o oleoduto clandestino, determina a imediata nacionalização da Standard Oil.

Gumucio também descarta a participação das companhias de petróleo na disputa pelo Chaco. Ele escreve que a Bolívia

no logró tampoco el único objetivo que habría paliado em cierta medida la carnicería: um puerto sobre el rio Paraguay para romper la angustiante asfixia de la mediterraneidad impuesta por Chile desde $1879 .^{21}$ (GUMUCIO, 1996, p. 48)

Klein (2008) defende a tese de que a Guerra do Chaco tem sua origem nas consequências negativas trazidas pela depressão de 1929 à Bolívia, além da necessidade de que o governo boliviano tinha de deter a torrente de manifestações populares contrárias ao seu modo de conduzir a política econômica. Klein também trata como "crença popular" a tese que a Guerra do Chaco foi um conflito em torno do subsolo encharcado de petróleo, levando à

\footnotetext{
${ }^{21}$ Tradução livre: Não alcançou o único objetivo que balizou em certa medida a carnificina: um porto no rio Paraguai para romper a asfixia da mediterraneidade imposta pelo Chile desde 1879.
} 
disputa entre as companhias petrolíferas já citadas. Para esse autor, o petróleo não é o estopim da guerra. Ele se torna alvo de cobiça apenas no final do conflito, quando as tropas paraguaias chegam próximas às escarpas andinas. O confisco da Standard Oil e a criação do monopólio estatal do petróleo são frutos diretos dessa crença.

\subsubsection{O FIM DO CONFLITO}

O presidente Toro, que já não contava mais com o apoio dos militares, foi retirado do poder por meio de um golpe militar impetrado pelo tenentecoronel Germán Busch Becerra, em 13 de julho de 1937. Busch prometeu continuar com a linha "socialista" iniciada por seu antecessor, porém, de acordo com Gumucio (1996), incorporando a saudação romana com o braço direito levantado.

Em 1938, foi escrita uma nova constituição para a Bolívia. A Assembleia que a concebeu também ratificou Germán Busch no cargo de Presidente Constitucional da República e aprovou a negociação de um acordo que colocasse fim ao conflito com o Paraguai.

O fim do conflito ocorreu com a assinatura do Tratado de Paz, Amizade e Limites de 21 de julho de 1938, que estabeleceu uma comissão, presidida pela Argentina, a fim de delimitar a fronteira entre os dois países, fixada em 23 de janeiro de 1939 (mapa 10, página 131).

Com o fim da Guerra do Chaco, grandes transformações ocorreram na Bolívia, segundo Viotti:

No plano político, resultou na superação do sistema vigente desde 1880, com a crise tanto dos governos civis quanto dos partidos políticos tradicionais. No plano econômico, a Guerra do Chaco, associada aos efeitos da Grande Depressão, marcou o fim da expansão da indústria mineira, cuja produção e produtividade começaram a declinar. Com o início do declínio da mineração, passaram a adquirir maior importância as 
riquezas do Oriente boliviano, especialmente o petróleo (VIOTTI, 2000, p. 188)

Após o conflito, o Paraguai passou a ter grande importância para a Bolívia no sentido de alcançar a saída para o oceano Atlântico, via o corredor formado pelos rios Paraguai e Paraná, para poder escoar sua produção, pois no Tratado de Paz, de 21 de julho de 1938, a Bolívia foi contemplada com um porto livre no rio Paraguai.

A Guerra do Chaco foi verdadeiramente uma guerra nacional, que envolveu pessoas de todas as partes da Bolívia, principalmente indígenas e mestiços pobres. Vale destacar o que escreveu Urquidi:

O Chaco simboliza mais que a fragilidade de um projeto estatal. A derrota e a perda do território do Chaco desencadearam nas colunas do exército as bases contemporâneas do nacionalismo boliviano, uma vez que, no cenário da guerra e na centralização das ações pelo exército, juntaram-se pela primeira vez os setores dispersos da sociedade, que comportavam a essência da nação: a pequena burguesia urbana, os artesãos, os camponeses e os mineiros.

Diferentemente do que ocorreu na Guerra do Pacífico, quando a participação estatal e a convocação social boliviana foram escassas, para o Chaco acudiu gente de todos os cantos do país, que se reuniu e se reconheceu como pertencente a um mesmo território que precisava ser defendido.

Por isso, a guerra, mais do que a derrota do Estado oligárquico, significou o encontro das massas dispostas a construir um sentimento nacional a partir da única instituição centralizadora que era o exército. (URQUIDI, 2007, p. 76)

Essa derrota não foi apenas militar, mas expressou também a crise do próprio Estado boliviano, na sua forma historicamente dada de imposição do metabolismo social, marcada pela exclusão política das camadas populares. A condução da guerra, marcada pelo enorme desperdício de vidas humanas, expressou a velha lógica criolla de abusar das populações indígenas e 
mestiças. O morticínio apenas havia passado das minas para os canhões. Por outro lado, a Guerra do Chaco marcou o surgimento de uma consciência nacional.

Começam a se discutir questões até então "proibidas" pelos donos do poder, como as demandas indígenas, trabalhistas, agrárias, além das assuntos relativos à dependência econômica da Bolívia e ao domínio da chamada "rosca"22, a oligarquia formada por Simon I. Patiño, que chegou a controlar 50\% da produção do estanho boliviano. Os outros 50\%, conforme Gumicio (1996), estavam divididos entre as empresas de Carlos Victor Aramayo, de família boliviana e do alemão Maurício Hochschild.

Concretamente, a população passa a reivindicar uma participação maior no destino dessa sociedade, onde o Estado da elite boliviana não se preocupou em se tornar Nacional, até mesmo para melhor exercer suas condições de hegemonia.

Portanto, a perspectiva "nacional" (incluindo as lutas contra o Capital e o resgate da cidadania da população indo-americana) passa a pertencer às lutas das massas populares, e essa experiência de luta passa moldar o bloco histórico de camponeses e operários, culminando na Revolução de 1952.

\footnotetext{
${ }^{22}$ De acordo com Ayerbe, o adjetivo rosca se origina "por causa dessa limitada capacidade de irradiação dos benefícios da prosperidade para o conjunto do país, o setor era conhecido popularmente como 'rosca', porque girava em torno de si mesmo". (AYERBE, 2002, p. 96)
} 
Situação não rara na América Ibérica, onde Estados territoriais precederam às nações, a Bolívia explicita o drama histórico das entidades políticas surgidas do colonialismo moderno.

Urquidi afirma que "o grande momento constitutivo da história contemporânea boliviana é a Revolução Nacional de 1952, cujas bases sociais se formaram antes, desde a Guerra do Chaco (1931-1935), nas colunas do exército, onde camponeses, operários e setores urbanos nacionalistas se encontraram pela primeira vez." (URQUIDI, 2007, p. 35) Paradoxalmente, a derrota boliviana na Guerra do Chaco faz emergir uma consciência nacional no espectro societário até então dispersa na sociedade boliviana, formada por mineiros, camponeses, artesãos, além da pequena burguesia urbana. Esses grupos entram em contato e se interpenetram. Tal sentimento nacionalista foi centralizado pelas patentes intermediárias do exército.

Es el tránsito de la nación fáctica a la nación para si mesma y del país resistente al país histórico en un proceso por el cual, después de haber resistido a la negación de la nación, las clases que la contienen, niegan la negación de la nación y tratan de realizar un Estado nacional. ${ }^{23}$ (MERCADO, 1967, p. 63)

Neste contexto surgiram alguns grupos de esquerda, principalmente 0 Movimiento Nacionalista Revolucionario (MNR) em junho de 1942, formado por operários, camponeses, ex-combatentes da Guerra do Chaco e um núcleo pequeno-burguês oriundo da oligarquia decadente. O elemento índio foi, pela primeira vez, incorporado em um projeto nacional. A Guerra do Chaco estava

\footnotetext{
${ }^{23}$ Tradução livre: É a transição da nação de facto à nação para si mesma e de um país resistente em um país histórico, em um processo pelo qual, tendo resistido a negação da nação, suas classes, negam a negação da nação e tratam de realizar um Estado nacional.
} 
tão presente no pensamento dos fundadores do MNR que José Cuadros Quiroga, um de seus principais dirigentes fez constar a seguinte frase no programa do partido:

Somos una consecuencia de la guerra del Chaco. Después de la perdida del litoral, ninguna catástrofe tuvo en la historia de la República poder convulsivo mas tremendo, resultados tan vertiginosos y corrosivos, ni nada sacudió tan hondamente el alma nacional. ${ }^{24}$ (QUIROGA apud GUMUCIO, 1996, p. 127)

Novas determinações surgem com a reação das classes subalternas a este processo. A mineração havia socialmente produzido concentrações localizadas, porém densas, de operários. Estes vão incrementando sua ação sindical e formando agremiações políticas, além do já citado MNR, cabe destacar a criação do Partido Obrero Revolucionario (POR) em 1935; do Partido de Isquierda Revolucionaria (PIR) em 1940 e da Federación Sindical de los Trabajadores Mineros Bolivianos (FSTMB) em junho de 1944.

Junto à crescente organização do campesinato e dos trabalhadores, a partir de meados da década de 1930, a instalação de federações operárias por departamento demonstra que as demandas étnicas eram expressão das contradições sociais e econômicas.

Vale ressaltar o surgimento das famosas Teses de Pulacayo, fruto de um congresso da Federação dos Mineiros do distrito de Pulacayo, realizado em outubro de 1946. Esse documento sindical, redigido pelo líder trotskista Guillermo Lora, do Partido Obrero Revolucionario, serviu de bandeira da oposição operária até 1952.

Entre outras indicativas, as Teses propunham a escala móvel dos salários, a redução da jornada de trabalho, a ocupação operária das minas e o controle da produção pelos trabalhadores. Tudo isso foi uma tentativa de armar a classe trabalhadora para a ação revolucionária, com respostas políticas práticas nesse momento de ascensão da classe operária, visando à implantação do socialismo na Bolívia. As teses constituíam-se de um programa

\footnotetext{
${ }^{24}$ Tradução livre: Somos uma consequência da guerra do Chaco. Depois da perda do litoral nenhuma catástrofe teve na história tamanho poder convulsivo, resultados tão vertiginosos e corrosivos, nem nada sacudiu tão profundamente a alma nacional.
} 
sindical adaptado do Programa de Transição, escrito por Leon Trotski e base da fundação da IV Internacional. Porém, apesar de ousadas, as Teses ficaram distantes da classe para a qual era dirigida, pois esta estava mais vinculada aos ideais nacionalistas, incorporados pelo MNR, que assumiu as tarefas de modernização nacional.

É importante ressaltar que durante a Segunda Guerra Mundial, apesar do movimento ascendente da classe trabalhadora boliviana, o Estado boliviano estava envolvido no chamado "esforço da guerra contra o nazi-facismo", alinhando-se incondicionalmente com os Estados Unidos. Esse alinhamento incondicional foi o responsável, de acordo com Whitehead (1996), pela nacionalização da empresa aérea Lloyd Aéreo Boliviano ${ }^{25}$, fundada em 1925 por cidadãos alemães. Além disso, Gumucio (1996) afirma que esse apoio incondicional dado aos Estados Unidos fez com que o governo, nas mãos do Major Gualberto Villarroel, determinasse a prisão e posterior envio aos Estados Unidos de todos os alemães e japoneses residentes na Bolívia, acompanhados de suas respectivas famílias.

De acordo com Gumucio (1996), nesse período, o governo boliviano acertou um contrato de venda, por cinco anos, de tungstênio com a empresa estadunidense Metal Reserve Corp ao preço de 21 dólares a unidade de 20 libras, bem abaixo do preço de mercado mundial ${ }^{26}$. Além do tungstênio, comercializava o estanho com a mesma empresa, a 40 centavos de dólar por libra, sendo que seu preço deveria ser de 52 centavos de dólar por libra. É necessário lembrar que a Bolívia era o único produtor de estanho do mundo não controlado pelos países do eixo. A Malásia, outro grande produtor de estanho, estava sob o controle do Japão.

$\mathrm{Na}$ ânsia de cumprir os contratos de fornecimento de minérios para os Estados Unidos, caía sobre os ombros dos trabalhadores o esforço de guerra, que se apoiava em baixos salários e na exploração da mão-de-obra. Protestos e marchas de trabalhadores cresciam na mesma proporção que a repressão estatal, que culminou com o massacre de Cataví, quando foram assassinados

\footnotetext{
${ }^{25}$ Empresa privatizada em 1995 e adquirida pela brasileira VASP.

${ }^{26}$ Segundo cálculos de Gumucio (1996, p. 220), a ajuda econômica dos Estados Unidos para a Bolívia, no período de 1946 a 1974, incluindo doações e os créditos bancários, alcançaram a cifra de US\$664.700.000,00 e a ajuda boliviana aos Estados Unidos pelo congelamento dos preços dos minerais durante a Segunda Guerra Mundial chegou a US\$ 670.315.000,00.
} 
21 trabalhadores. De acordo com Mercado (1967), o MNR, pela denúncia enérgica do massacre, torna-se o partido dos mineiros bolivianos.

Whitehead (1996) escreve que após o final da Segunda Guerra Mundial, o preço do estanho foi descongelado, porém, o mercado começou a ser dominado pelos Estados Unidos graças ao seu grande estoque do produto. Aliado a isso, aconteceu a reinserção de países produtores de estanho do extremo oriente, desaquecendo o mercado boliviano. Com isso, a produção da Bolívia, que era quase $50 \%$ do total mundial em 1945 , caiu para cerca de $30 \%$ em 1947 e para menos de 20\% em 1950. Com a redução dos lucros, a oligarquia mineira intensificou a repressão e a violência contra as massas trabalhadoras.

Nesse contexto de agitação, começa a emergir o rosto de uma classe até então afastada de qualquer tipo de decisão sobre seu destino.

A Revolução de 1952 foi fruto, sobretudo da ascensão da classe operária, que se colocou contra os desmandos de um setor dirigente da burguesia boliviana.

Na leitura de Wasserman, essa revolução produziu

a mais poderosa referência de identidade desde a criação da República boliviana. Funcionou como resposta à frustração das 'guerras perdidas' e fortaleceu a centralidade do Estado como agente da construção simbólica da comunidade nacional. O Estado de 1952 foi projeto destinado a instituir uma comunidade cultural - a nação boliviana -, através de um processo de homogeneização cultural, que foi imaginado como uma síntese entre as culturas indígenas e a cultura ocidental. A rede onde circulava esta narrativa era o sistema educacional, a política cultural e o serviço militar obrigatório, mediante os quais o povo deveria fazer uma aprendizagem de cidadania e nacionalismo. (WASSERMAN, 2004, p. 321)

A eleição presidencial de 1951 foi vencida por Victor Paz Estenssoro, do MNR, porém, a oligarquia reinante, na figura do presidente Mamerto Urriolagoitia, não aceitando o resultado da eleição, procedeu em maio do mesmo ano, um autogolpe denominado "mamertazo". Delegou-se o poder a 
uma junta militar, representada pelo general Ovidio Quiroga, que nomeou como presidente do país o também general Hugo Ballivián. Este declarou a ilegalidade dos partidos de oposição e reprimiu com violência as manifestações populares que marchavam pelo país contra a chamada "Junta Usurpadora". O MNR começou a armar seus principais quadros, abrindo caminho para a insurreição de massas em 9 de abril de 1952.

A vitória popular foi avassaladora. O exército não resistiu a mais de três dias de combates e deserções, sendo desarmado e dissolvido pela própria insurreição. As massas, apesar de vitoriosas, entregaram o poder à pequena burguesia. Em 13 de abril de 1952 o poder foi reentregue a Victor Paz Estenssoro. Configura-se, dessa maneira, o caráter democrático-burguês da Revolução. Nesse sentido, vale a afirmação de Mercado:

Primeiramente, o poder foi dar em mãos da frente de massas e, por um momento, se concentrou na classe operária. Depois, vista a impotência das massas ante si mesmas, o poder foi dar em mãos, no essencial, da pequena burguesia em seu conteúdo pré-burguês. Mas de qualquer maneira, não há dúvida de que aqui uma classe substitui a outra, que um Estado se ergueu sobre a destruição do anterior e que o papel decisivo foi desempenhado pelas massas. (MERCADO, 1988, p. 44)

Inicia-se uma aliança entre o MNR e a COB (Central Obrera Boliviana), fundada em 17 de abril de 1952, por iniciativa das diversas organizações de trabalhadores, artesãos, estudantes e intelectuais, cuja direção coube ao dirigente sindical Juan Lechin Oquendo. Esse co-governo colocava o MNR no poder, mas com fiscalização e controle da COB, para evitar que a Revolução fosse traída.

As consequências imediatas da Revolução foram a nacionalização, com indenização, das minas, em 31 de outubro de 1953 e a criação de uma grande empresa estatal para administrá-las, a Corporación Minera de Bolivia (COMIBOL), seguida por uma portentosa reforma agrária, também instituída em 1953, em face da extrema concentração de terras existentes na Bolívia, sua 
repartição foi uma maneira de melhorar as condições de vida dos trabalhadores rurais.

Dentro da COB, o POR defendia que as ferrovias também deveriam ser estatizadas, pois até aquele momento elas eram controladas pela rosca (oligarquia estanhífera). Tal ato se tornou realidade em 1967 com a unificação das ferrovias bolivianas, formando a estatal Empresa Nacional de Ferrocarriles (ENFE). Ao longo dos anos, essa empresa foi sucateada, seja por erros cometidos pela administração ou pela opção rodoviarista implantada a partir da década de 1970, quando estradas de rodagem foram construídas paralelamente às ferrovias existentes.

A Empresa Nacional de Ferrocarriles foi privatizada em 1996 durante o primeiro mandato de Gonzalo Sánchez de Lozada, dando origem a duas empresas distintas. A empresa estadunidense Genesse \& Wyoming controla e opera a malha ferroviária oriental, que possui cerca de 1.220 quilômetros, ligando Santa Cruz de la Sierra até a fronteira com o Brasil e a Yacuiba, na divisa com a Argentina. A empresa Bolivian Railways, pertencente a chilenos, opera a malha ferroviária ocidental, que possui cerca de 2.320 quilômetros, com um ramal ligando a Bolívia à fronteira com a Argentina passando por Uyuni e Tupiza, e outro destinado ao Chile. Estas duas malhas ferroviárias não estão interligadas (Mapa 9, página 124).

A população indígena passa a contar com direitos civis. O Estado passa a ser o principal agente de desenvolvimento, pois o programa da pequena burguesia no poder, representada pelo MNR, de acordo com Mercado (1988), era a unidade nacional, a construção do Estado Nacional, e tudo isso entendido como a reconstrução da burguesia, mas desta vez em termos nacionais, seguindo ideias nacionalistas e de centralismo estatal.

O novo governo boliviano, porém, teve de enfrentar o pagamento de excessivas indenizações ${ }^{27}$ aos antigos proprietários das minas, que já demonstravam uma tendência ao esgotamento. Além disso, segundo Mercado (1988), os antigos proprietários mantiveram o controle de setores chaves da mineração, impedindo a instalação de fundições e outros elementos inerentes à mineração.

\footnotetext{
${ }^{27}$ De acordo com Ayerbe (2002, p. 99), as indenizações pagas pela expropriação alcançaram o montante de US\$22 milhões.
} 
Além desses percalços, os ativos estavam em péssimas condições, os preços do estanho estavam em queda no mercado internacional. O governo, em função da mudança da razão social das minas, pagou indenização de desligamento a todos os mineiros e os recontratava imediatamente. Concomitantemente, as exportações de estanho diminuíam ano após ano. Conforme Ayerbe, "entre 1952 e 1960, as exportações diminuem de 136 para 55 milhões de dólares, das quais 84\% são destinadas aos Estados Unidos e à Inglaterra". (AYERBE, 2002, p. 99)

A reforma agrária, apesar de aliviar a vida dos camponeses, não conseguiu, em um primeiro momento, diminuir a importação de alimentos. Os reflexos não demoraram a atingir o mercado interno, sucumbindo a uma espiral inflacionária de grande envergadura, comparada por Gumucio (1996) com a inflação que abalou a Alemanha após a Primeira Guerra Mundial, causando falta de alimentos e empobrecimento de grande parcela da população.

De acordo com Gumucio (1996), abriu-se assim o caminho para a retomada do poder pela classe média, em 1956, representada por Hernán Siles Zuazo, do setor moderado do MNR. Zuazo recebeu um enviado econômico do governo dos Estados Unidos, George Jackson Eder para tentar solucionar os problemas econômicos da Bolívia que aumentaram, fundamentalmente, em função da diminuição do preço do estanho no mercado internacional, concomitante com o aumento nos gastos internos.

George Jackson Eder atuou respaldado pelo Fundo Monetário Internacional (FMI) e com plenos poderes, impondo, em 1956, um plano de estabilização monetária (Plano Eder) que, segundo Gumucio (1996), desvalorizou o peso boliviano, aboliu os preços subvencionados dos artigos de primeira necessidade, eliminou o controle sobre as importações e as exportações, liberalizando o comércio exterior e congelou salários por um ano. Além disso, o acordo obrigou a Bolívia retomar o pagamento da dívida externa, suspenso desde 1931. O vice-presidente Nuflo Chavez renunciou ao cargo denunciando que, por intermédio de uma empresa estadunidense, George Jackson Eder havia comprado uma parte considerável dos bônus da dívida externa boliviana, vendidos a ele com preços muito abaixo do valor de mercado. 
Para Ayerbe (2002), os Estados Unidos tinham assumido um compromisso interno com a América Latina, no bojo da Guerra Fria. No caso boliviano, um governo de esquerda nacionalista poderia ser um transtorno caso esse país resolvesse se aproximar da União Soviética.

A preocupação dos Estados Unidos em relação à América Latina no início da Guerra Fria se concentra, especialmente, nas posturas nacionalistas de alguns governos e movimentos que visualizam uma perspectiva equidistante da influência do país como base para qualquer política de afirmação nacional. (ibidem, 2002, p. 81)

Mesmo com as manifestações dos trabalhadores contra essas medidas, inclusive acusando o governo do MNR de ter se vendido para os Estados Unidos, de ter se afastado da defesa da classe trabalhadora e de trair os princípios revolucionários de 1952, o Plano Eder foi de fato, colocado em prática, marcando o início do rompimento do co-governo MNR/COB, que ocorreu efetivamente com a publicação de um decreto governamental cancelando, de maneira definitiva, essa forma de governo.

A partir desse período, a Bolívia começou a mover-se sob os auspícios econômicos dos Estados Unidos, desenvolvendo sua economia nos padrões exigidos por aquele país.

$\mathrm{Na}$ leitura de Mercado,

o projeto norte-americano para a Bolívia consistia em suprimir seus focos de independência classista ou democracia política, como os mineiros e as esquerdas e construir uma ditadura à maneira das de Trujillo, Somoza ou Stroessner. (MERCADO, 1988, p. 65)

Portanto, no final da década de 1950, assiste-se a um "Termidor" na Bolívia, com a desmobilização política das camadas subalternas. Porém, os padrões de dominação também se modernizaram pelo alto. Concretamente, a burguesia continuou a manter sua configuração oligárquica, porém, imperativos da própria transnacionalização (tempos da Aliança para o Progresso e do take- 
off rostowiano) criara necessidades de popularizar a imagem de uma sociedade capitalista democrática, gestada na igualdade de oportunidades, mesmo não ocorrendo uma implantação de fato (modernização das condições materiais e expansão da liberdade política) deste modelo social.

O plano estadunidense, que transitou na economia e na política, previa também a ruptura concreta dos laços entre o MNR e o movimento operário. Na eleição de 1960 o MNR apresenta-se dividido. O setor mais à direita, denominado MNR Autêntico, funda, por razões eleitorais, o PRA (Partido Revolucionario Auténtico) e apresenta o conservador Walter Guevara Arce como candidato. A esquerda do MNR lança o líder Paz Estenssoro, que ganha as eleições com o apoio da classe trabalhadora.

Entretanto, nesse mandato de Paz Estenssoro, os bolivianos que esperavam um presidente que resgatasse os ideários revolucionários de 1952 se deparam com um governo legalista e de continuidade do governo moderado de Siles Zuazo, no que tange ao cumprimento dos acordos com os Estados Unidos e, por extensão, na repressão ao movimento operário.

Começa a partir do governo Paz Estenssoro, nas palavras de Gumucio (1996), um verdadeiro "carnaval de greves" e, no final de 1963, a vanguarda dos trabalhadores bolivianos, os mineiros, agrupados em um congresso em Colquiri, declarou sua oposição ao regime e seu rompimento definitivo com o MNR.

O período de governos do MNR, a partir de 1952, foi interrompido com um golpe de Estado, há apenas 89 dias depois de Paz Estenssoro haver iniciado seu terceiro mandato. O golpe foi perpetrado pelo General da Força Aérea René Barrientos, oriundo das próprias fileiras do MNR, em 4 de novembro de 1964. Barrientos é fruto do reordenamento do exército boliviano nos padrões estadunidenses, moldado a partir do próprio período revolucionário. Ayerbe (2002) afirma que, a partir de 1953, a maioria dos novos ingressos no colégio militar boliviano era enviada para cursos na escola do Pentágono, no Canal do Panamá, destinada aos oficiais latino-americanos. Comparativamente, a Bolívia enviou a maior porcentagem de militares em relação aos outros países do continente.

Mercado afirma que 
Foram os serviços de inteligência norte-americanos que montaram as campanhas políticas de Barrientos, primeiro como vice-presidente de Paz, depois como chefe do golpe que derrubou o MNR, logo como co-presidente junto de Ovando, finalmente como ditador da Bolívia. (ibidem, 1988, p. 62)

Verifica-se que Barrientos foi alçado ao cargo de presidente da Bolívia com a ajuda da CIA que, de conforme a leitura de Ayerbe (2002), foi responsável por dois objetivos: a informação e a ação encoberta. Sua chegada ao poder serve para dar estabilidade ao cumprimento dos acordos assinados com os Estados Unidos, diminuindo, dessa maneira, o poder da classe trabalhadora na direção do Estado boliviano.

Assim, tem início o período chamado de "populismo militar", caracterizado pela perseguição contra os movimentos sociais e o rebaixamento geral dos salários dos trabalhadores mineiros. A COB foi posta na ilegalidade e seus líderes enviados para o exílio. As greves foram reprimidas com violência numa tentativa bem sucedida de isolar o chamado "perigo sindical".

O golpe militar na Bolívia foi uma retomada dos interesses dos Estados Unidos na Bolívia. O capital de origem estadunidense não só passa a circular com maior desenvoltura, como também as concessões para a exploração das jazidas mineiras são remanejadas para empresas dos Estados Unidos.

Andrade escreve que "o General Barrientos entregou os setores mais rentáveis da economia nacionalizada para empresas estrangeiras, praticamente retornando à situação anterior à revolução de 1952, de saque sistemático dos recursos naturais e humanos do país." (ANDRADE, 2005, p.144) Para tal, aliou-se com setores políticos da direita boliviana, retirados do poder na Revolução de 1952, em aliança com as empresas multinacionais que atuavam no país. Entre essas estava a Gulf Oil que, de acordo com Gumucio (1996), fez contribuições generosas à Barrientos e a seus correligionários no valor de US\$460.000,00, dos quais US\$110.000,00 serviram para comprar o helicóptero exigido por ele.

Em 1966, o General Barrientos ganhou as eleições para a presidência da Bolívia, diante do boicote dos partidos de oposição que apelaram para o voto em branco. Uma nova constituição foi aprovada e, entre outros artigos, 
extinguiam-se as milícias populares, além de uma nova reforma agrária e a manutenção da nacionalização da mineração, mas sem o controle operário.

O governo de Barrientos, marcado pela morte do revolucionário Ernesto "Che" Guevara assassinado na selva boliviana, terminou com a morte do presidente, devido à queda do helicóptero em que se encontrava, no dia 27 de abril de 1969.

Em seu lugar, dando continuidade ao governo Barrientos, assume o vice-presidente Luis Adolfo Siles Salinas, que permanece no cargo por cinco meses, até ser derrubado por um golpe militar liderado pelo general Alfredo Ovando Candia, em 26 de setembro de 1969.

Gumucio (1996) escreve que as Forças Armadas lançam um manifesto, encabeçado pelo general Ovando que, entre outros pontos, promete assegurar a soberania nacional sobre os recursos minerais e sobre a indústria mineira, proteger o capital nacional, melhorar a vida dos trabalhadores e manter a luta pela reintegração do território litorâneo perdido para o Chile.

Com esse discurso, Ovando mostra-se um nacionalista e começa a realizar uma abertura democrática, permitindo a reabertura dos sindicatos e o funcionamento dos partidos políticos. Seu gesto mais espetacular foi a nacionalização da Gulf Oil Co. (Bogoc), quando "revogou o código de 1955 e decretou em 17 de outubro de 1969, a nacionalização da Bogoc, confiscando todos os seus bens e anulando suas concessões, com o compromisso de pagamento de uma indenização". ${ }^{28}$ (ALEXANDRE, 2006, p. 16) Além disso, segundo Gumucio (1996), o governo Ovando decretou o monopólio estatal na comercialização dos minerais produzidos na Bolívia, que ficou centralizado no Banco Mineiro da Bolívia.

Ao sofrer pressões da elite direitista boliviana, Ovando fez um governo dúbio, quando ao mesmo tempo proclamava atos anti-imperialistas, reprimia a luta dos trabalhadores.

No dia 4 de outubro de 1970, Ovando é derrubado por outro golpe militar desferido pelo general direitista Rogelio Miranda. No dia 7 de outubro de 1970 a COB convoca uma greve geral, ajudando o general Juan José Torres Gonzáles, um oficial progressista, a chegar ao poder. Torres propôs um

\footnotetext{
${ }^{28}$ No valor de US\$ 102 milhões.
} 
governo conjunto com a COB, oferecendo à central sindical 50\% dos ministérios, logo aceito pela central sindical desde que, conforme escreve Andrade (2007), os ministros ligados à COB fossem eleitos pelas organizações populares e que seus mandatos poderiam ser revogados a qualquer tempo.

Em janeiro de 1971, o general Hugo Bánzer tenta derrubar o governo do general Torres por intermédio de um golpe de Estado, que não se concretizou. No mesmo mês e ano, a COB propõe constituir uma Assembleia Popular, como órgão de poder operário, e exige do governo Torres o reconhecimento da mesma. As forças populares, numa demonstração de unidade, criaram no dia primeiro de maio de 1971 a chamada Assembleia Popular. Esta foi marcada por uma forte mobilização popular e com a participação da grande maioria das organizações de massas, configurando uma situação de dualidade de poder, colocando em xeque o governo do general Torres, que permanecia no poder apoiado por uma fração do exército.

Gumucio (1996) afirma que, apesar da importância política conquistada pela Assembleia Popular, esta esbarrava nas disputas entre os diversos grupos de esquerda, que disputavam entre si, qual deles era o mais à "esquerda". Além disso, os participantes da Assembleia Popular eram, em sua esmagadora maioria, representantes dos trabalhadores do meio urbano, que representavam aproximadamente $20 \%$ da população, enquanto a massa camponesa, cerca de 70\% da população, não possuía sequer representação.

A Assembleia Popular é derrotada por um golpe militar de direita, impetrado em 21 de agosto de 1971, novamente pelo general Hugo Banzer Suarez, que estava preso em La Paz, mas que possuía uma boa retaguarda em Santa Cruz. Procedia de lá seu apoio político ligado à elite local e o apoio militar prestado pelo regimento "Manchego" dos Rangers bolivianos, comandado pelo coronel Andrés Selich Shop. De acordo com Gumucio (1996), esses não pouparam munição na caça aos dirigentes das entidades populares ligadas à Assembleia Popular.

Apesar da grande resistência armada popular que durou cinco dias, alicerçada no grande número de pessoas dispostas a lutar, faltavam-lhes armas. Assim, a Assembleia foi dissolvida e mais uma ditadura militar instalava-se não só na Bolívia, como também na América Latina, com apoio da ditadura militar brasileira que daria "retaguarda estratégica, recursos 
financeiros e material bélico" (MELLO, 1997, p. 155). Caso houvesse qualquer problema para que os militares bolivianos tomassem o poder, o exército brasileiro estaria a postos para ajudá-los diretamente. Mello escreve que o Brasil "tinha a ideia de instauração de um 'protetorado' sobre a Bolívia." (ibidem, p. 127)

Segundo Gumucio (1996), a queda do general Torres representou um refluxo das esquerdas e uma virada política e econômica do país à direita, porém sem abandonar o estilo estatizante e centralizador, inspirado no modelo adotado pelo governo militar brasileiro.

\subsection{O ORIENTE BOLIVIANO}

O departamento de Santa Cruz foi criado em 1826, logo após a independência boliviana. Possui extensão de $370.621 \mathrm{~km}^{2}$. Ao norte da capital Santa Cruz de la Sierra se localizam os melhores solos.

De acordo com Rodrigues (2004), esta cidade não possuía, até meados do século $\mathrm{XX}$, contato por terra com outros centros urbanos. Além disso, era dominada por uma elite fundiária ali baseada desde o período colonial, que vivia do abastecimento de produtos pecuários para o restante da Bolívia. Esse isolamento foi fundamental para que essa elite se mantivesse no poder local por um longo período, fazendo inclusive o papel do Estado ao manter, por exemplo, milícias particulares.

Como, a partir da Revolução de 1952, a ideia de integração nacional tornou-se necessária para a consolidação do Estado boliviano, o oriente do país, mais precisamente o departamento de Santa Cruz - por meio de grandes investimentos estatais - começa a ser integrado. Para isso, foram indispensáveis a construção, em 1953, de uma rodovia ligando Santa Cruz de la Sierra a Cochabamba e de duas ferrovias ligando, a Bolívia ao Brasil e à Argentina. Assim, "sob uma intensa promoção do processo de acumulação a partir do aparelho do Estado, gera-se outro polo burguês moderno, o da burguesia capitalista agrícola." (MERCADO, 1988, p. 47)

Os investimentos em Santa Cruz também ganharam um grande impulso durante a ditadura banzerista na década de 1970, em função da concessão de 
farto crédito estatal para a expansão das lavouras de exportação e da pecuária de corte.

Garcia (2000) enfatiza que foi a partir dos investimentos estatais no oriente boliviano, na segunda metade do século $X X$, que o eixo econômico do país se inverteu, pois até aquele momento concentrava-se no eixo La Paz Oruro - Cochabamba. A partir dos investimentos estatais, passou a ser La Paz - Cochabamba - Santa Cruz (Mapa 7).

Andrade salienta que a reforma agrária implantada em 1953 fez surgir na região de Santa Cruz grandes empresas agrícolas que investiram principalmente no cultivo do algodão, do arroz, da cana-de-açúcar, da soja e do café. Já na década de 1950, a Bolívia se tornou autossuficiente na produção de arroz e açúcar. "Os projetos de colonização da região de Santa Cruz foram estabelecidos, sobretudo para aliviar a pressão demográfica e reivindicativa nas grandes concentrações do altiplano." (ANDRADE, 2007, p. 119) Tanto é que, no período entre 1954 e 1962, a população do departamento de Santa Cruz duplicou, seja em função de migrações internas proporcionadas pelo programa de colonização ou pela chegada de levas migratórias que, segundo Gumucio (1996), vinham do Chile, Argentina, Brasil, Japão, além de pessoas ligadas à comunidade evangélica menonista. Em função do forte adensamento populacional no altiplano, a reforma agrária de 1953 tinha como intenção fazer que a pequena propriedade rural do altiplano abastecesse o mercado interno e que o oriente boliviano fosse responsável pela agricultura capitalista moderna de exportação.

A reforma agrária também tinha como intenção proporcionar a colonização da distante e isolada Santa Cruz de la Sierra, no sentido de expandir a fronteira agrícola do país, "onde seria dada prioridade às médias e grandes propriedades, capitalizadas, voltadas para a agroindustrialização exportadora". (COSTA NETO, 2005, p. 117) Vale salientar que o dinheiro dos empréstimos realizados pelos Estados Unidos para o financiamento da agricultura boliviana era direcionado exclusivamente para Santa Cruz, para o desenvolvimento de uma agricultura moderna, comercial e rentável, fortalecendo ainda mais a elite rural desse departamento. 


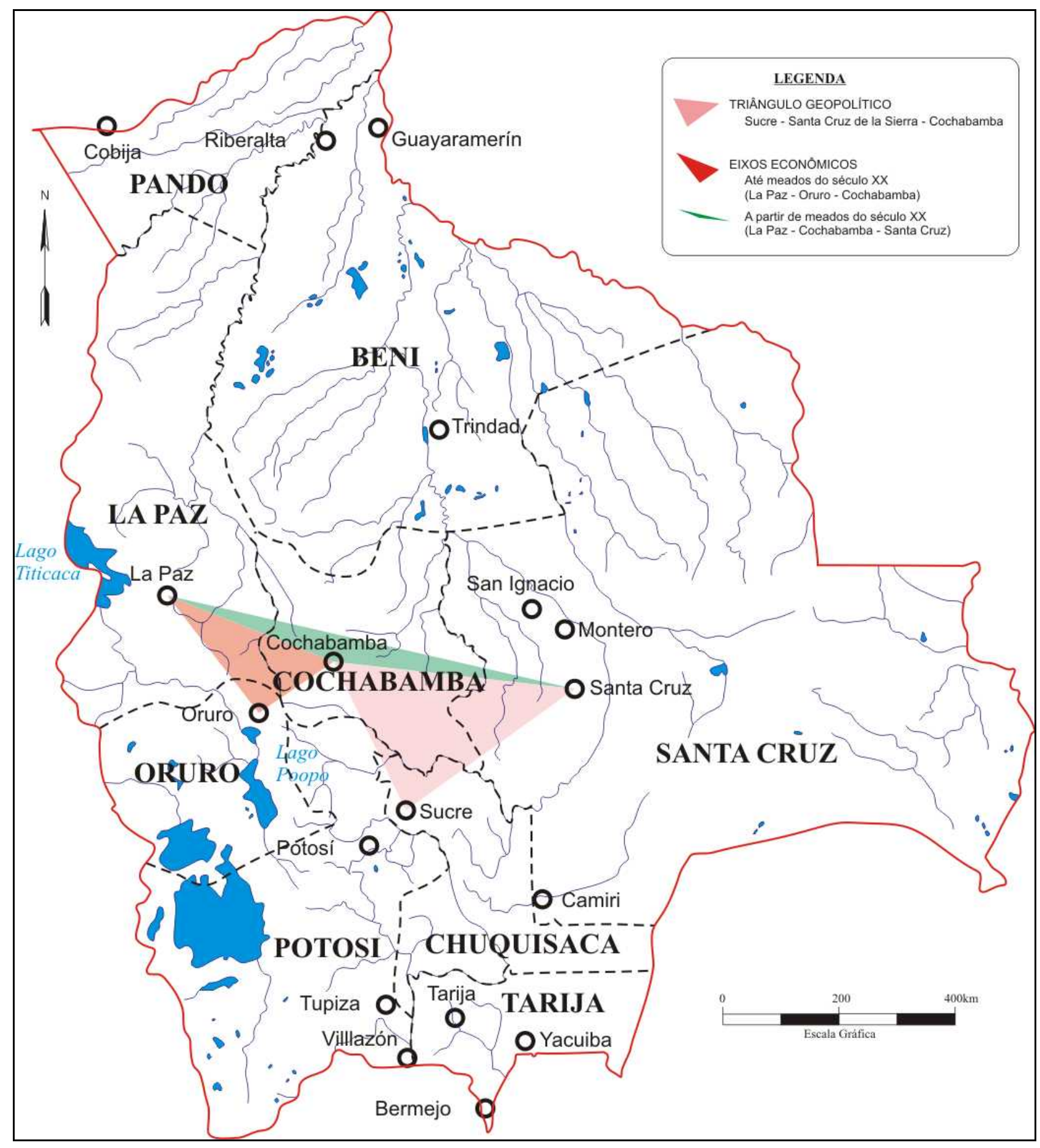

Mapa 7

Eixos econômicos e triângulo geopolítico da Bolívia (MELLO, 1997, p. 67 e NATIONAL GEOGRAPHIC, 2008, p. 34 - adaptado) 
Tal direcionamento vem desde a "Missão Bohan" que visitou a Bolívia em $1942^{29}$, orientando os investimentos para o oriente do país. A partir dos direcionamentos propostos pela comissão, surgiu o primeiro instrumento de integração, a rodovia Cochabamba - Santa Cruz, construída em 1953, e a única rodovia pavimentada até então, para permitir a ligação efetiva de Santa Cruz com o restante da Bolívia.

Segundo Whitehead (1996), a missão Bohan, comandada pelo economista estadunidense Merwin Bohan, propôs um investimento de oitenta milhões de dólares por intermédio da criação de uma companhia de desenvolvimento. Foi criada a Corporación Boliviana de Fomento, com um presidente boliviano e um gerente geral estadunidense. De acordo com Costa Neto (2005), a partir da década de 1960 a Corporación Boliviana de Fomento foi a responsável por conceder financiamentos gigantescos para a agroindústria e a pecuária no oriente boliviano que serviram para a compra de aviões, construção de matadouros, além de investir na construção de estradas vicinais e no desenvolvimento agrícola de Santa Cruz, via generosos incentivos governamentais. Estes, a partir de meados da década de 1950, se concentraram no departamento de Santa Cruz, em detrimento dos outros departamentos.

Vale ressaltar que, em 5 de outubro de 1963, o governo do MNR criou a estatal "Servicio Nacional de Camiños", em substituição ao "Servicio Cooperativo Boliviano Americano de Camiños", que havia sido criado em 1955 com assistência técnica e econômica do governo dos Estados Unidos, e cuja finalidade seria manter, administrar e construir novas rodovias, no intuito de integrar todo o território boliviano. Nos dias de hoje, a empresa que administra as estradas bolivianas é a "Administradora Boliviana de Carreteras", uma autarquia de direito público criada em 27 de outubro de 2006 pelo governo de Evo Morales, em substituição ao "Servicio Nacional de Camiños", extinta na mesma data.

Mesmo com uma maior participação do Estado, seja em função dos novos negócios agrários ou pela presença em Santa Cruz de la Sierra da sede

\footnotetext{
${ }^{29}$ Mesmo ano em que foi fechado o acordo para a indenização da empresa petrolífera estadunidense Standard Oil, nacionalizada em 1937.
} 
das companhias de petróleo e gás, cujas jazidas se localizam em Tarija e Cochabamba, o controle político permaneceu nas mãos da elite local.

Esses investimentos estatais e o efetivo crescimento econômico conquistado fizeram com que Santa Cruz, nos termos usados no relatório do Programa das Nações Unidas para o Desenvolvimento (PNUD) de 2004, passasse de periferia a centro, dentro do escopo econômico boliviano mediado numa relação ao mesmo tempo conflitiva e proveitosa.

A partir do golpe de Estado impetrado pelo general Hugo Banzer, em 1971, o Brasil volta a dirigir grandes investimentos para o oriente boliviano, destacadamente em Santa Cruz de la Sierra, sobretudo no que tange ao aproveitamento do gás natural e de petróleo, acordados no Convênio de Cochabamba, no qual a Bolívia se

comprometia a fornecer ao país-irmão 240 milhões de pés cúbicos diários de gás natural, por um prazo de 20 anos, totalizando 1,7 trilhões de metros cúbicos. Em contrapartida, o Brasil se comprometia a construir o gasoduto Brasil-Bolívia (GASBOL), uma usina petroquímica e uma refinaria em Cochabamba, uma usina siderúrgica para a jazida de El Mutum e a conexão ferroviária entre Santa Cruz de la Sierra e Cochabamba. (PFRIMER, 2009, p. 342)

As negociações evoluíram e culminaram, segundo Viotti (2000), na assinatura em 22 de maio de 1974 do Acordo de Cooperação e Complementação Industrial, com investimentos voltados para as áreas de siderurgia, fertilizantes, cimentos e hidrocarburetos.

\subsection{O INTERESSE DO BRASIL E DA ARGENTINA}

Segundo Mello (1997), Mário Travassos, considerado o pai-fundador do pensamento geopolítico brasileiro e influenciado pela teoria geopolítica de 
Halford Mackinder ${ }^{30}$, concebe o triângulo (mapa 7, página 112) formado por Sucre, Santa Cruz de la Sierra e Cochabamba como sendo o heartland ${ }^{31}$, a região-pivô do continente sul-americano, por isso, controlar a Bolívia e seu heartland é dominar política e economicamente a América do Sul.

Ao trabalhar com a influência de Mackinder no pensamento geopolítico de Mário Travassos, Mello (1997) faz a seguinte analogia:

Quem dominar o triângulo econômico boliviano, controlará a Bolívia; quem dominar a Bolívia, controlará o coração da América; quem dominar o coração da América, controlará o continente sul-americano. (MELLO, 1997, p. 153)

Para Travassos, Cochabamba é o principal vértice do triângulo econômico, mas o deslocamento dessa qualidade para Santa Cruz de la Sierra foi fundamental para as pretensões brasileiras e dominar o heartland sulamericano é condição necessária para possuir a hegemonia na América do Sul.

Pfrimer (2009) salienta que é a partir da Segunda Guerra Mundial que a preocupação de Travassos ganha corpo, pois o Brasil e a Argentina começam a disputar a hegemonia sul-americana para tornar-se o aliado preferencial dos Estados Unidos na América do Sul. Para tanto,

Apoiando-se nas teorias geopolíticas construídas pelos militares, as duas potências procuraram expandir a sua rede de transportes, criando, assim, uma dependência dos países mediterrâneos (Bolívia e Paraguai) em utilizá-las. Essa satelitização dos países sem costa marítima passou, então, a ser o principal objetivo de Brasil e Argentina. Na visão geoestratégica desses dois países, a Bolívia se situa em uma área estratégica a ser influenciada, uma vez que ali há ricas jazidas de vários minerais. Ademais, no território boliviano se

\footnotetext{
${ }^{30}$ Halford John Mackinder (1861-1947). Geógrafo britânico e pai da teoria da "existência de uma rivalidade secular entre dois grandes poderes antagônicos que se confrontavam pela supremacia mundial: o poder terrestre e o poder marítimo". (MELLO, 1999, p.11)

31 "Termo cunhado pelo geógrafo inglês Halford Mackinder para designar a região-pivô ou coração continental da Eurásia. Essa região-pivô era constituída pelo núcleo interior, com uma área de 23 milhões de km²." (ibidem, p. 292)
} 
encontra o divortium aquarium sul-americano, ou seja, as nascentes das principais bacias hidrográficas da América do Sul se situam ali, e ter acesso a elas significa ter contato com diferentes partes do continente, o que é considerado símbolo de poder. (PFRIMER, 2009, p. 340)

Para Travassos, a cidade de Santa Cruz de la Sierra poderia tornar-se o centro do triângulo econômico boliviano, pois "representa o verdadeiro centro de gravidade da economia do planalto" (TRAVASSOS, 1935, p. 45), pois além de situar-se mais próxima do Brasil e de possuir agricultura diversificada, possui reservas de petróleo. Travassos (1935) considerou Santa Cruz de la Sierra o carrefour (cruzamento) econômico do centro do continente, podendo neutralizar o sistema ferroviário argentino. A atração dessa cidade poderia ser vital para a alteração da correlação de forças que pendia naquele momento para a Argentina. Travassos (1935) advoga que uma das possibilidades de atração de Santa Cruz de la Sierra poderia se feita pela ligação dessa localidade com a ferrovia Madeira-Mamoré, oferecendo uma opção de deslocamento fluvial entre Santa Cruz de la Sierra e a Madeira-Mamoré pela utilização do rio Grande, na Bolívia. A outra e principal possibilidade seria a ligação, por ferrovia, de Santa Cruz de la Sierra até o porto de Santos, no estado de São Paulo.

Porém, no início do século XX, em face de certo desinteresse ou mesmo de uma falta de investida mais vigorosa do Brasil em fazer da Bolívia sua área de influência, a Argentina se encarrega desse papel, principalmente oferecendo ao país andino o prolongamento de suas ferrovias e a possibilidade de escoamento de seus produtos pelo porto de Buenos Aires. Nas palavras de Mello (1997), essa ligação sul-norte daria o predomínio geopolítico na América do Sul para a Argentina, em prejuízo do Brasil.

A fim de conseguir deslocar o eixo de atração da Argentina para o Brasil, a solução proposta por Travassos seria construir uma ferrovia, no sentido oeste-leste, que ligasse Santa Cruz de la Sierra até Puerto Suarez, na divisa com o estado de Mato Grosso, no Brasil. Tal ferrovia deveria realizar essa função com bastante eficiência, para não reforçar a opção de utilização do rio 
Paraguai, favorecendo o eixo sul-norte e assim beneficiando ainda mais a Argentina.

Segundo Azevedo (s.d.), a primeira tentativa em ligar o oriente boliviano com o Brasil por meio de uma ferrovia remonta a 1865, mas a preocupação com a Argentina já estava presente desde o início do século $\mathrm{XX}$, quando Euclides da Cunha lança sua inquietação com os destinos da produção do oriente boliviano, que estava sendo escoada pelo porto de Buenos Aires. Para Cunha, o melhor destino das mercadorias bolivianas seria o porto de Santos, em São Paulo, que teria ao seu lado a menor distância com a Europa em relação ao de Buenos Aires.

No entanto, por volta de 1935 o governo brasileiro parte para a ofensiva, no momento em que o Brasil começou a recear que o oriente boliviano ficasse sob domínio da Argentina que, na figura do seu chanceler Carlos Saavedra Lamas, teve uma participação preponderante e fundamental nos acordos de paz entre o Paraguai e a Bolívia, fazendo esta última passsar à influência argentina. Tamanha foi a ação diplomática de Lamas que ele foi agraciado com o prêmio Nobel da Paz e pela honraria mais alta concedida pelo governo boliviano, o "Condor de los Andes".

Até 1935, o Brasil declarava-se neutro no conflito entre a Bolívia e o Paraguai, pois não era interessante desgastar-se perante seus vizinhos. Porém, de acordo com Bieber (2000), faltando cinco meses para a assinatura de paz entre esses países, o Brasil decide alinhar-se à Bolívia. O Brasil, possivelmente, ficou incomodado com a liderança argentina no processo de paz da Guerra do Chaco e começou a "estruturar ou implementar mecanismos de conciliação que questionassem as prerrogativas conferidas à Conferência de Buenos Aires." (BIEBER, 2000, p. 219)

Em 1936, o chanceler brasileiro Macedo Soares propôs ao Ministro das Relações Exteriores da Bolívia, Enrique Finot, a compra de um porto sobre o rio Paraguai, proposta prontamente recusada pelo ministro boliviano. Com a recusa, Macedo Soares ainda tentou persuadir o ministro boliviano com a promessa de concessões brasileiras ao Paraguai para a obtenção de facilidades à Bolívia. Bieber (2000) afirma que Macedo Soares chegou a oferecer ao Paraguai um elevado empréstimo concedido pelos Estados Unidos, um porto no Brasil, a construção de uma ferrovia e a reorganização de um 
banco paraguaio em troca da cessão de um porto franco para a Bolívia. Tal proposta foi rejeitada tanto pela Bolívia quanto pelo Paraguai.

O porto livre no rio Paraguai para uso da Bolívia foi enfim conseguido na assinatura do Tratado de Paz, em 21 de julho de 1938.

A Bolívia quis capitalizar a seu favor a disputa entre Brasil e Argentina, colocando-se ao lado daquele em detrimento deste, pois naquele momento o Brasil "oferecia oportunidades mais promissoras para a causa andina que a conferência em Buenos Aires" (BIEBER, 2000, p. 223), principalmente no que tange a escolha de um "porto em correspondência mais direta com seu planalto central." (TRAVASSOS, 1935, p. 64) Travassos pensava no porto de Santos, "a cerca de cinco graus ao Sul do paralelo de Santa Cruz." (ibidem, p. 166) As negociações entre o governo brasileiro e o governo boliviano foram rápidas haviam sido iniciadas em 1936 - e, em fevereiro de 1938, levaram os dois países a

assinar um tratado ferroviário (Tratado sobre vinculado ferroviário entre Corumbá e Santa Cruz de la Sierra), que previa a construção da ferrovia Corumbá - Santa Cruz de la Sierra, e um tratado petroleiro (Tratado sobre saída e aproveitamento do petróleo boliviano), um acordo sobre a exploração do petróleo na região leste da Bolívia a partir do rio Parapeti em direção ao norte do país, antes que a Argentina tomasse a mesma iniciativa. (VEZENTINI, 2004, p. 366)

Segundo Viotti (2000), de acordo com o Tratado Sobre Ligação Ferroviária, além da ligação principal entre Santa Cruz de la Sierra e Corumbá, a Bolívia se encarregaria de construir com ajuda do Brasil

a ferrovia de Vila a Santa Cruz de la Sierra, bem como o ramal de Santa Cruz de la Sierra a Puerto Grether ou outro ponto navegável no rio Ichilo, com o objetivo de ligar o oriente boliviano ao Altiplano e ao Pacífico. Comprometia-se também o Governo boliviano a construir, por sua conta, a estrada Santa Cruz de la Sierra - Camiri e a concluir a ligação Sucre - Camiri. (VIOTTI, 2000, p. 189) 
De acordo com Azevedo (s.d.), os custos da construção da ferrovia entre Santa Cruz de la Sierra até a fronteira com o Brasil seriam arcados pelo Brasil, em razão do não cumprimento da construção do ramal da estrada de ferro Madeira-Mamoré, que deveria atingir a cidade de Vila Bela, na Bolívia. O saldo da construção era de um milhão de libras esterlinas. O valor que passasse desse montante seria emprestado pelo Brasil à Bolívia, com juros de 3,5\%, que a Bolívia pagaria com o fornecimento de petróleo para o Brasil.

Para facilitar esse empreendimento, já estava em operação a Estrada de Ferro Noroeste do Brasil ${ }^{32}$ que, desde 1914, fazia a ligação entre Bauru e Porto Esperança, na fronteira do Mato Grosso com a Bolívia, às margens do rio Paraguai. Para chegar ao porto de Santos, bastava alcançar em Bauru o entroncamento com a Sorocabana ou Paulista até São Paulo e, desse ponto, utilizar os trilhos da Santos-Jundiaí até o porto de Santos (Mapa 8).

Caberia ao governo brasileiro construir o trecho entre Porto Esperança e o local do ponto de contato entre as ferrovias, na cidade de Corumbá, localizada próxima à fronteira com a Bolívia e vizinha da cidade boliviana de Puerto Suarez.

Esses tratados foram rapidamente assinados, pois tinham o objetivo de fortalecer a aproximação com a Bolívia e tentar afastar a Argentina da disputa por este país, uma vez que tanto o Brasil quanto a Argentina se constituíam em mercados naturais para o petróleo da Bolívia. A construção da estrada de ferro tinha um objetivo bastante claro. Essa ferrovia "representará poderosa força de atração atuando sobre as linhas desse país que se projetam para o levante, à procura do sistema ferroviário brasileiro." (AZEVEDO, s.d., p. 185), ou ainda, "o ato de mais profunda significação política nos tempos que correm". (TRAVASSOS, 1935, p. 167)

\footnotetext{
${ }^{32}$ Esse nome passou a vigorar a partir de 1917, depois que a empresa foi encampada pelo governo brasileiro.
} 


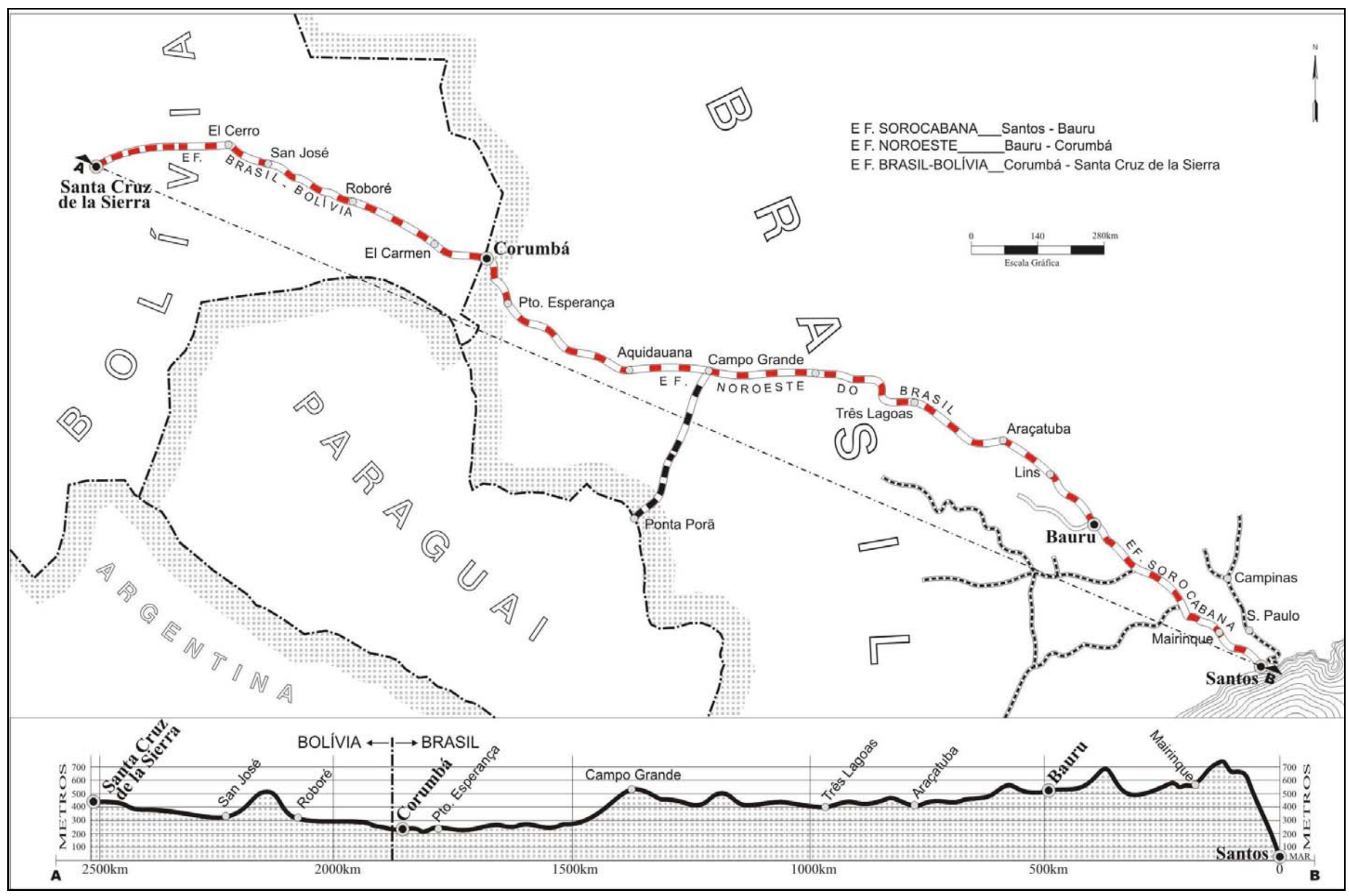

Mapa 8

Estrada de ferro Santa Cruz de la Sierra-Santos (AZEVEDO, s/d., p. 183 - adaptado)

- 120 - 
A Argentina, por outro lado, também se aproximou da Bolívia, assinando com a mesma, em 1937, um contrato de exploração conjunta do petróleo boliviano, que interessava ao governo argentino, pois este importava o produto de países mais distantes. Antes que essa aproximação tomasse corpo, o Brasil acelerou a preparação dos tratados com a Bolívia. Tais acordos não impediram o aumento da influência argentina sobre a Bolívia, pois desde o início do século XX essa já se fazia sentir graças à construção, em 1915, de um ramal ferroviário entre La Quiaca, na Argentina, e Tupiza, no sul da Bolívia, cujo intuito era absorver o comércio do oriente boliviano.

A Argentina continuava em negociações com a Bolívia e, em setembro de 1936, o ministro das relações exteriores argentino, Saavedra Lamas, envia Horácio Carrillo à Bolívia, para discutir a construção de uma ferrovia ligando a cidade argentina de Yacuiba até a cidade boliviana de Santa Cruz de la Sierra.

Após as negociações, Bieber (2000) escreve que em 1941 a Bolívia assina com a Argentina um "Tratado de Vinculado Ferroviária", muito parecido com os tratados assinados com o Brasil, versando sobre a exploração de petróleo e a construção de um oleoduto e também sobre a construção de uma ferrovia, que estava sendo pensada desde o início do século XX, ligando Santa Cruz de la Sierra até a cidade argentina de Yacuiba. Isso desagradou o governo brasileiro, pois abria à Argentina o acesso a uma área que estava destinada à exploração brasileira. Segundo Pfrimer (2009), ficava clara a intenção do governo argentino em diminuir a influência brasileira no oriente boliviano.

Azevedo (s.d.) acrescenta que a Argentina, no início do século $X X$, já tinha planos de realizar um sistema ferroviário transcontinental, a chamada Pan American Railway, articulando Buenos Aires, Assunción, La Paz e Lima. Isso levou Inácio Calderón, ministro boliviano em Washington, a sugerir a formação dos Estados Unidos da América do Sul, formados por Peru, Bolívia, Chile, Argentina, Uruguai e Paraguai, grosso modo, recompondo as fronteiras do Vice-Reinado do Rio da Prata.

A Bolívia via nos acordos com o Brasil a possibilidade de integração interna entre o oriente e o ocidente do país e, principalmente, a perspectiva de alcançar o Atlântico via articulando a cidade de Santa Cruz de la Sierra com o rio Paraguai e o porto de Santos. Nos acordos com a Argentina, o objetivo era 
o mesmo, porém, para alcançar o Atlântico por esse país, o porto vislumbrado era o de Buenos Aires. Gumucio afirma que para a Bolívia esses acordos eram fundamentais para tirá-la de seu isolamento internacional para que

realizara em plenitud su función de centro integrador (como único país que forma parte de los sistemas del Pacifico, del Amazonas y del de la Plata), pusiera en movimiento la riqueza potencial del país y obtuviese la cooperación económica de los países vecinos para abrir nuevas vías de comunicación y transporte. Tal programa se plasmaba en la construcción de los ferrocarriles que vincularan a importantes redes ferroviarias continentales; en el aprovechamiento de puertos fluviales para el comercio internacional boliviano; en la vinculación terrestrefluvial com Paraguay y con Uruguay; la doble salida al Atlántico (Buenos Aires y Santos); en la transformación y progreso de los departamentos de Tarija, Chuquisaca y Santa Cruz, uniéndose a los ferrocarriles argentinos y brasileños; en la utiización, com fines nacionales, de una riqueza antes solamente en potencia y que por un imperativo geográfico deriva hacia Argentina y Brasil ${ }^{1}$. (GUMUCIO, 1996, p. 104)

Para o Brasil, a assinatura dos acordos não só facilitou a aproximação com o país vizinho, atraindo-o para a órbita brasileira, como fez vislumbrar a possibilidade de alcançar o oceano Pacífico por intermédio de uma ligação entre a ferrovia Santa Cruz de la Sierra-Corumbá e a ferrovia Arica-La Paz.

Todavia, as ligações secundárias no interior da Bolívia, não foram realizadas e a ligação ferroviária entre Corumbá e Santa Cruz de la Sierra somente ficou pronta em janeiro de 1955, segundo Bieber (2000), em função

\footnotetext{
${ }^{1}$ Tradução livre: Em desempenhar plenamente o seu papel de centro integrador (como o único país que faz parte dos sistemas do Pacífico, do Amazonas e do Prata), colocar em movimento a riqueza potencial do país e obter a cooperação econômica dos países vizinhos para abrir novas vias de comunicação e transporte. Esse programa é consubstanciado na construção de ferrovias ligando às principais redes ferroviárias do continente; no aproveitamento de portos fluviais para o comércio internacional boliviano; na vinculação terrestre-fluvial com o Paraguai e o Uruguai; a dupla saída para o Atlântico (Buenos Aires e Santos); na transformação e progresso dos departamentos de Tarija, Chuquisaca e Santa Cruz, unindo-os às ferrovias argentinas e brasileiras; no uso para fins nacionais de uma riqueza que antes apenas potencialmente e por um imperativo geográfico tendia para Argentina e Brasil.
} 
ora da falta de recursos financeiros, ora pela falta de recursos materiais ou ainda sobre as disputas entre os dois governos pelo trajeto que a ferrovia deveria seguir.

A ligação tão almejada pelo Brasil entre o Pacífico e o Atlântico, raciocinada desde o Plano Ferroviário de 1890, pensado por André Rebouças, até hoje não se completou, pois existe um hiato, cujo ponto fulcral seria a ligação de aproximadamente $630 \mathrm{~km}$, entre Cochabamba e Santa Cruz de la Sierra, que deveria fazer a ligação entre a ferrovia La Paz-Arica e Santa Cruz de la Sierra-Corumbá. Esta lacuna dividiu a malha ferroviária boliviana em duas, a malha ferroviária oriental e a malha ferroviária ocidental (mapa 9). Hoje, ambas estão privatizadas.

De acordo com Azevedo (s.d.), esse pequeno trecho entre Cochabamba e Santa Cruz de la Sierra, que também seria a responsável pela integração da parte andina com a planície, era pensado desde o plano ferroviário do engenheiro Hans Grether, elaborado em 1923, que em sua análise, resolveria o problema da viação interna da Bolívia.

Azevedo (s.d.) escreve que a construção da ligação ferroviária entre Santa Cruz de la Sierra e Cochabamba, iniciado em 1928, não se consumou em virtude de diversas crises econômicas e da falta de dinheiro para completála, apesar de o governo Hernando Siles Reyes ter contratado um empréstimo ${ }^{2}$ nos Estados Unidos para sua construção, como também de outra ferrovia que ligaria La Paz à Beni.

No final da década de 1940 surgiu um vigoroso debate nacional - a ferrocarril ou carretera (ferrovia ou rodovia), que agitou a imprensa boliviana. A discussão girava na escolha entre duas opções, pois não havia dinheiro para a concretização das duas formas de ligação: i) adiava-se a construção da estrada de ferro para concluir a ligação por uma estrada de rodagem; ii) concluir rapidamente a ferrovia e deixar a finalização da rodovia para um segundo momento.

\footnotetext{
${ }^{2}$ Esse empréstimo, denominado Dillon Reed, segundo Chiavenato (1979) foi utilizado para compra de armas para a Guerra do Chaco.
} 


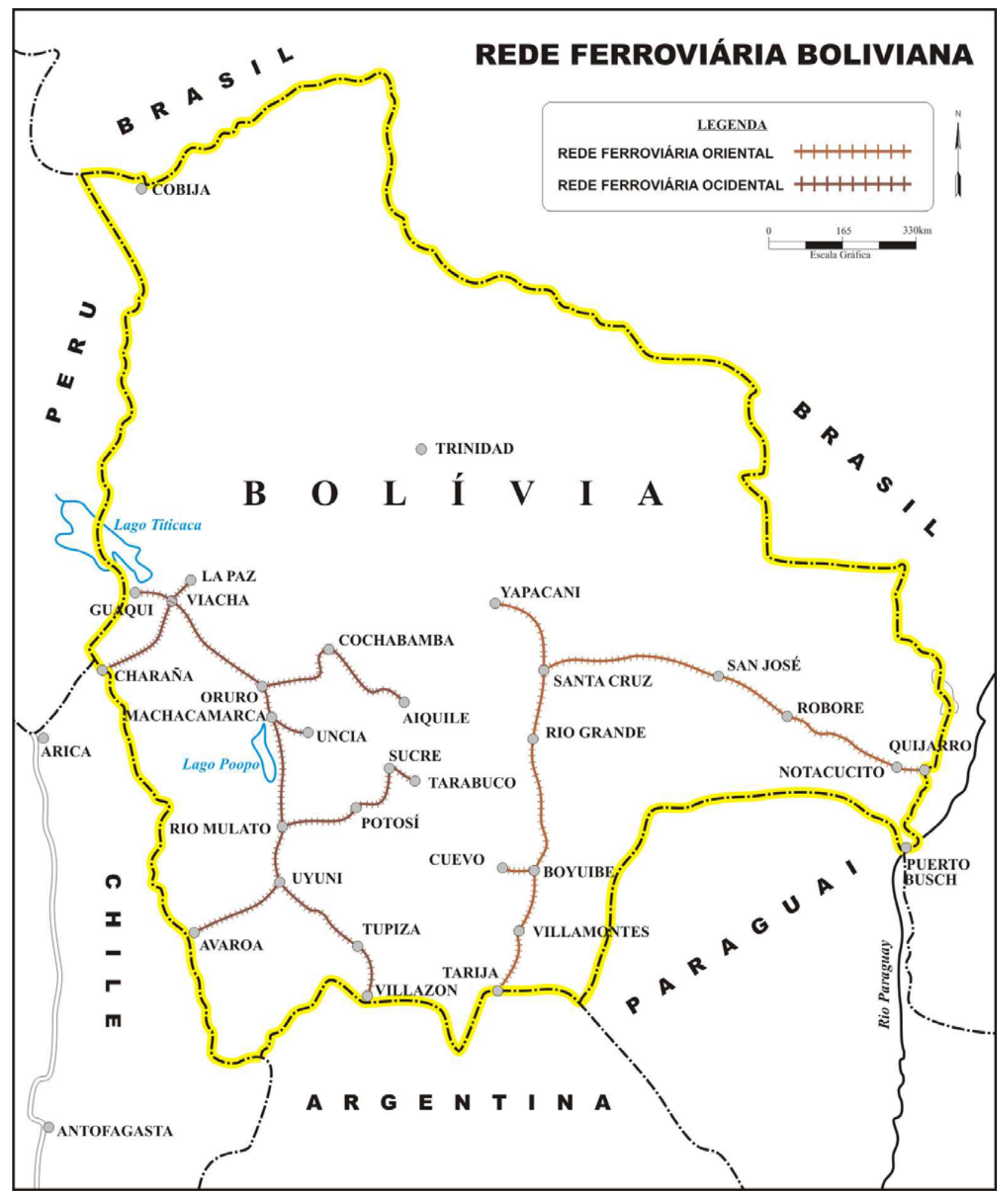

\section{Mapa 9}

Rede ferroviária boliviana

(disponível em: <http://www.umss.edu.bo/epubs/etexts/downloads/26/1.htm>. Acesso em 08 dez. de 2009 - adaptado) 
O posicionamento favorável à rodovia partia do jornal La Razón, que sustentava a tese de que essa seria menos onerosa, mais curta e requereria um tempo menor de construção, além de o valor do frete rodoviário ser mais barato do que o frete ferroviário.

O jornal Los Tiempos agrupava os defensores da solução ferroviária. Estes argumentavam que devido ao investimento de grandes somas na construção de $18 \mathrm{~km}$ de ferrovia, não se deveria abandoná-la. Além disso, alertavam o fato de que a rodovia era financiada com dinheiro dos Estados Unidos (Plano Bohan), e que o governo boliviano somente poderia pedir verbas para a construção àquele país, amarrando dessa maneira a edificação da rodovia aos humores estratégicos do governo estadunidense para a América do Sul. Assim, fica clara a influência dos Estados Unidos na política territorial boliviana e em sua integração territorial e, por extensão, na integração sulamericana.

Apesar dos posicionamentos penderem a favor da ferrovia, ela não se concretizou por falta de verbas federais. Para Azevedo (s.d.), a questão financeira não deveria ser um impedimento para sua construção, pois ao contrário de uma rodovia, a ferrovia se transformaria em um patrimônio público inventariável, uma espécie de anel ferroviário que se converteria em ponto de ligação de todas as ferrovias bolivianas e, fundamentalmente, colocaria Cochabamba no ponto central da ligação da Ferrovia Pan-americana. Além disso, a ferrovia se tornaria o centro de integração nacional. Sem essa ligação, as malhas ferroviárias do ocidente e do oriente não se conectariam, bloqueando possibilidades de expansão do comércio exterior boliviano.

A falta de dinheiro público para a construção e manutenção de obras é um problema bastante relevante para um país pobre. A Bolívia ainda tem um agravante, a sua geomorfologia, em que formas de relevo muito distintas devem ser interligadas.

É caro construir estradas nas regiões andina e subandina. A fragilidade do solo e as chuvas abundantes também encarecem a construção, e em especial da manutenção de estradas confiáveis na planície. A combinação 
desses fatores faz com que, uma vez construídas as estradas, os custos de transportes sejam na verdade mais baixos na região andina que na região de planície. Além de tudo, a Bolívia tem a menor densidade rodoviária (quilômetros por milhão de habitantes) entre todos os países sul-americanos. Apesar do grande crescimemento ocorrido entre as décadas de 1960 e 1990, o país ainda tem a menor extensão de estradas pavimentadas do continente. (GALLUP, GAVIRIA \& LORA, 2005, pp. 95-96).

Quanto à questão da exploração de petróleo, esta se arrastou por um longo tempo em função da difícil tarefa de determinar as áreas de estudos para prospecção, fazendo com que Bolívia e Brasil revisassem, na década de 1950, os tratados assinados em 1938. Em 1958 as negociações resultaram em um novo acordo, chamado de Ata de Roboré. "A tal ata pertencem o Convênio de Livre Trânsito, o Convênio de Cooperação Econômica e Técnica e o Convênio de Comércio Interregional, entre outros". (VIZENTINI, 2004, p. 367)

Foi por intermédio da Nota Reversal no 6 da Ata de Roboré, de 1958, que se permitiu pela primeira vez negociar o gás boliviano, sem ao menos se saber da viabilidade econômica da extração do produto. Na década de 1960, 0 interesse brasileiro pelo petróleo boliviano esmaeceu, pois era mais caro que o do Oriente Médio, uma vez que era controlado pela multinacional Gulf Oil.

Mesmo assim, a Bolívia passou de importadora à condição de exportadora de petróleo e gás natural. De acordo com Gumucio (1996), a produção boliviana de petróleo cru passou de 523.000 barris em 1952 para 3.132.000 barris em 1964. Até essa data, a Bolívia já possuía uma rede de oleodutos de aproximadamente 2.000 quilômetros.

Viotti (2000) destaca que foi a partir da década de 1970 que Brasil e Bolívia voltaram a conversar sobre os acordos de 1938 e sobre a Ata de Roboré de 1958, justamente durante os governos de Emílio Garrastazú Médici e de Hugo Banzer. Este queria dar prioridade máxima às relações de seu país com o Brasil, que passou a investir maciçamente no oriente boliviano, principalmente no departamento de Santa Cruz, a partir do golpe de Estado na Bolívia em 1971. 
Com o apoio decisivo aos golpistas bolivianos, ficou mais fácil para o governo militar brasileiro, num momento em que a geopolítica de Golbery do Couto e Silva imperava na Escola Superior de Guerra, trazer para a influência brasileira o que Golbery chamou de Área Continental de Soldadura, ou "uma área geopolítica de soldadura, caracterizada por seu notório caráter ambivalente amazônico-platino e que abrangeria, grosso modo, a Bolívia e o Paraguai, mais o estado de Mato Grosso e o território de Guaporé ${ }^{3 \prime}$. (SILVA, 1981, p. 89)

Mello (1997) argumenta que, com o golpe banzerista de 1971, apoiado pelo Brasil, e com a assinatura em 1974 do Acordo de Cooperação e Complementação Industrial, o Brasil atraiu para si o chamado heartland sulamericano conseguindo dessa maneira isolar as pretensões argentinas sobre a Bolívia.

\footnotetext{
${ }^{3}$ Atual estado de Rondônia.
} 


\section{CONSIDERAÇÕES FINAIS}

Partindo do pressuposto geopolítico de Travassos, de que está na Bolívia o triângulo que dá vida ao heartland sul-americano, a Bolívia deveria ser potente e conexa, mas o que observamos ao longo de sua história é exatamente o contrário. Trata-se de um Estado fraco e instável, tanto no que tange ao controle político, quanto no que tange à posse e controle de seu território. Afinal, a Bolívia já passou por mais de duzentos golpes de Estado e perdeu grandes porções de seu território para países vizinhos.

Nesta dissertação, procuramos mostrar o papel que as vias de circulação desempenharam na tarefa de dar coesão territorial, nos diversos momentos vividos pelo Estado boliviano, nos momentos de disputas externas ou internas. Além disso, buscamos demonstrar que a circulação é um processo vital para o Capital. Essa premissa é verificada desde a ocupação espanhola do território pré-boliviano até os dias de hoje.

A busca da coesão interna da Bolívia está vinculada às vias de circulação e, nesse sentido, a participação do Estado é fundamental para garantir a conformidade que se procura, pois, de acordo com Vallaux (1914), é apenas o Estado que abre e investe em caminhos para buscar sua unidade, seja pela cessão de uma concessão ou como agente financiador da empreitada. Dificilmente, o capital privado desempenhará esse papel, mesmo que para favorecê-lo.

Observamos que a cada disputa interestatal por territórios em que a Bolívia esteve envolvida, a compensação por suas perdas territoriais foi a construção de caminhos que impedissem o asfixiamento da economia boliviana. Por isso, o controle do Estado pelos grupos hegemônicos é de suma importância para garantir seus propósitos.

Karl Marx (1986), no Manifesto do Partido Comunista, de 1848, escreveu que a melhoria nos aparatos de produção e circulação leva a civilização até os países mais bárbaros, criando um mundo a sua própria imagem. A inserção do 
espaço colonial que veio a se tornar a Bolívia, no mundo dito civilizado, ocorreu em função das primeiras descobertas das riquezas minerais. Daí o esforço para a construção de caminhos que facilitassem o escoamento da prata andina para a metrópole e a sustentação dessas áreas, inserindo esse espaço colonial na economia-mundo.

Nos episódios de conflitos externos com perdas territoriais nos quais a Bolívia se envolveu, a disputa se realizou pela posse de fundos territoriais, ou seja, "áreas de soberania nacional ainda não incorporadas no tecido do espaço produtivo." (MORAES, 2005, p. 70)

Apesar de apresentarem problemas com as demarcações institucionais, as áreas perdidas para o Chile na Guerra do Pacífico, para o Brasil na Questão do Acre, e para o Paraguai na Guerra do Chaco pertenciam formalmente à Bolívia. No entanto, como, inicialmente, não despertavam nenhum interesse econômico, estas áreas permaneceram como fundos territoriais, com uma pequena presença estatal. Quando, porém, passaram a despertar interesse econômico, tais áreas foram ocupadas. Primeiramente, por populações de países vizinhos, que as transformaram em territórios usados, ou seja, "os espaços efetivamente apropriados" (MORAES, 2005, p. 70), causando disputas bélicas interestatais por sua posse. Isso resultou do fato de a Bolívia, apesar de possuir o domínio territorial, não possuir o domínio econômico para mantê-lo. Dessa forma, o Estado boliviano assistiu à balcanização de seu território, perdendo mais da metade de suas áreas em disputa (53,65\%) para seus vizinhos, conforme monstra o quadro a seguir e ilustrado no Mapa 10. Atualmente, o território da Bolívia conta com 1.095 .58 km² (Mapa 11). 


\begin{tabular}{|c|c|c|c|}
\hline \multicolumn{4}{|c|}{ As perdas territoriais da Bolívia com os seus vizinhos ${ }^{4}$} \\
\hline País & $\begin{array}{l}\text { Área } \\
\left(\mathbf{k m}^{2}\right)\end{array}$ & $\begin{array}{c}\text { Territórios perdidos } \\
\text { (\%) }\end{array}$ & $\begin{array}{l}\text { Forma como os territórios } \\
\text { foram perdidos }\end{array}$ \\
\hline Argentina & 170.758 & 13,50 & $\begin{array}{c}\text { Via diplomática por diferenças } \\
\text { limítrofes }\end{array}$ \\
\hline Brasil & 490.430 & 38,76 & Guerra do Acre e pela via diplomática \\
\hline Chile & 120.000 & 9,48 & Guerra do Pacífico \\
\hline Peru & 250.000 & 19,76 & $\begin{array}{l}\text { Via diplomática, por demarcações } \\
\text { fronteiriças }\end{array}$ \\
\hline Paraguai & 234.000 & 18,49 & Guerra do Chaco \\
\hline Total & 1.265 .188 & 100,00 & \\
\hline $\begin{array}{c}\text { Território } \\
\text { da Bolívia } \\
\text { em } 6 \text { de } \\
\text { agosto de } \\
1825 \\
\end{array}$ & 2.363 .769 & & \\
\hline $\begin{array}{c}\text { Território } \\
\text { atual da } \\
\text { Bolívia }\end{array}$ & 1.095 .581 & & \\
\hline
\end{tabular}

\footnotetext{
${ }^{4}$ As perdas territoriais da Bolívia com seus vizinhos (ARAÚJO, 2004, p. 390- adaptado)
} 


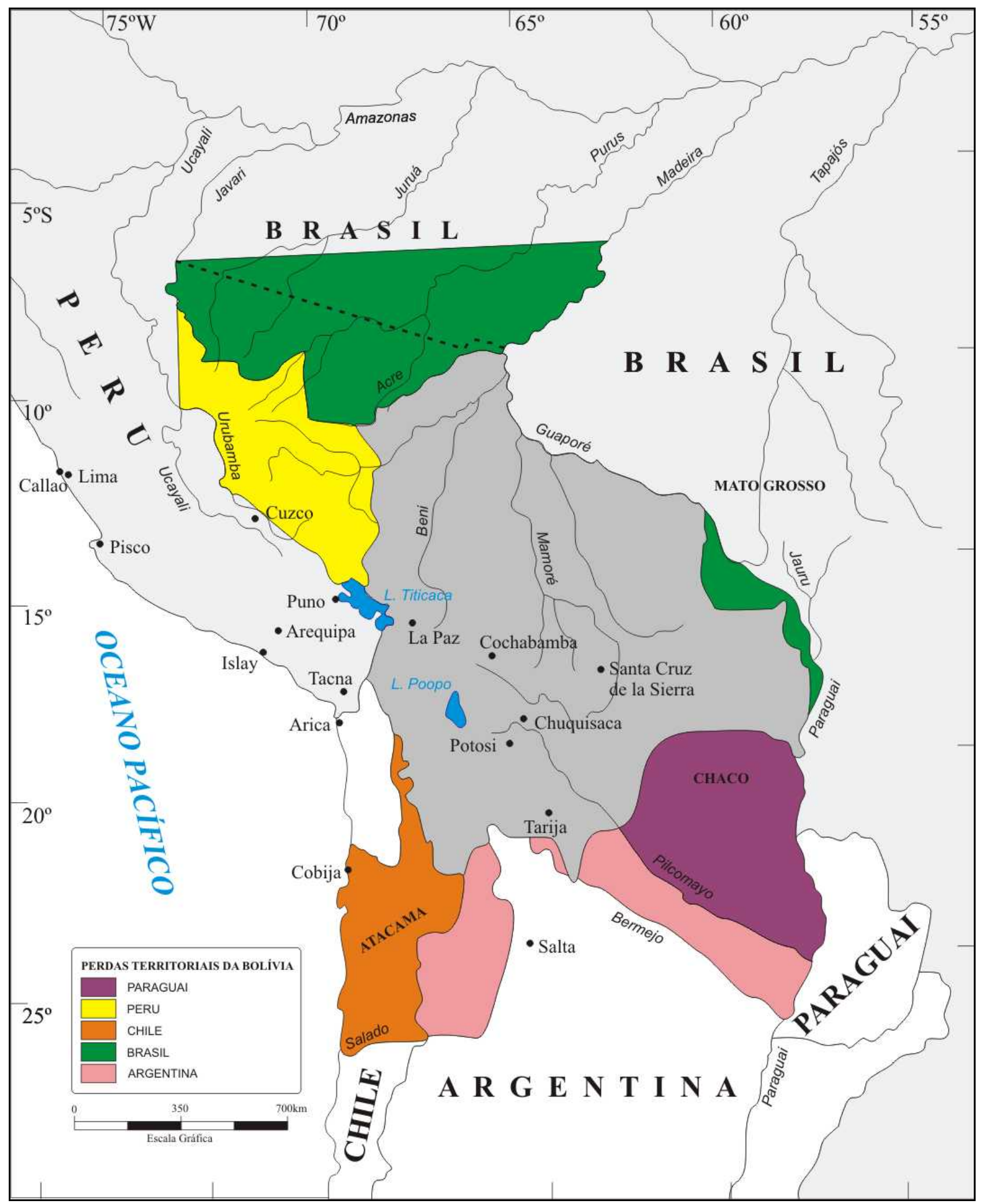

Mapa 10

Perdas territoriais da Bolívia (KLEIN, 1991, p. 72 - adaptado) 


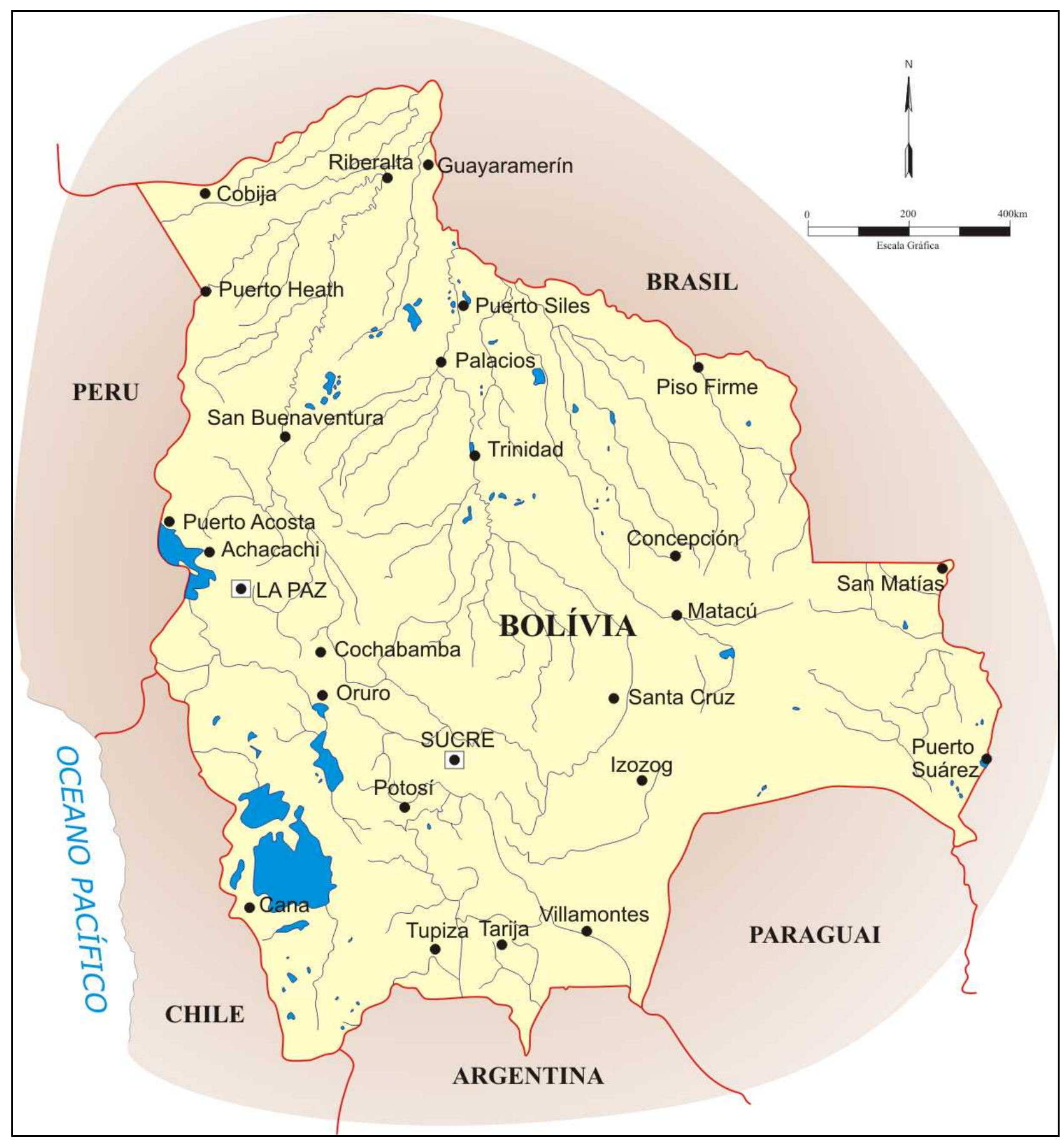

Mapa 11

Mapa do território atual da Bolívia (NATIONAL GEOGRAPHIC, 2008, p. 34 - adaptado) 
Portanto, após analisarmos os conflitos bélicos-territoriais, nos quais a Bolívia esteve envolvida, defendemos a posição que as análises calcadas no mero arrolamento de disputas e rivalidades políticas narradas pelo jornalismo ou a história tradicional, bem como a vitimização terceiro-mundista não dão conta de explicar a complexidade dos confrontos.

Ao perder gradativamente partes de seu território, a Bolívia se via impelida em garantir os movimentos circulatórios, tanto internos quanto externos, para não perder a coesão territorial, sob pena de um esfacelamento territorial causado pelo estrangulamento de suas ligações com o exterior.

Nesse contexto, a questão da circulação ganha relevância, pois a perda dos territórios citados culminou em um movimento de encontrar meios de o Estado boliviano poder manter seu comércio exterior, principalmente, porque as áreas perdidas possibilitavam o acesso, direto ou indireto, ao mercado mundial. Para a elite mineira não importava a perda do território boliviano, o que estava em jogo era a construção de alternativas viárias, bancadas pelo Estado, para o escoamento de sua produção.

Mário Travassos escreveu que o

problema das comunicações sobreleva no complexo dos demais problemas. No ponto de vista absoluto não há quem desconheça o papel que as comunicações representam na formação e mantença dos Estados. As comunicações podem mesmo definir o grau de aproveitamento das possibilidades de um país como de uma região, exprimir materialmente os objetivos que se prosseguem. (TRAVASSOS, 1935, pp. 184185)

Porém,

A política externa boliviana foi condicionada, historicamente, por sua posição geográfica, pela perda de acesso ao mar (e de $40 \%$ de seu território) e pela falta de integração interna, com insuficiente grau de consolidação do Estado nação. Considerada o 'Coração da América do Sul, 'País ponte' e país 
de contatos e gravitações múltiplas, o país está, de fato, inserido nas Bacias do Prata, Pacífico e Amazonas. (VIZENTINI, 2004, p. 383)

Vale acrescentar que a partir de 1971, limite temporal desta dissertação, alguns avanços foram verificados no que tange ao processo de integração calcada nos eixos de circulação no território boliviano. Os novos eixos viários, como o rodoviário, tiveram a intenção de ligar a zona subandina às planícies orientais, seguindo a expansão da fronteira agrícola para os departamentos de Beni e Pando. Além disso, insere-se nesse contexto o ousado projeto assumido entre os governos do Brasil e da Bolívia, em 1992, para a construção do Gasoduto Bolívia-Brasil (Gasbol), com 3.150 km, sendo 2.593 km em território brasileiro. O gasoduto começa na cidade boliviana de Santa Cruz de la Sierra e termina em Porto Alegre, cortando os estados de Mato Grosso do Sul, São Paulo, Paraná, Santa Catarina e Rio Grande do Sul, passando assim, por aproximadamente quatro mil propriedades localizadas em 135 municípios.

A utilização da hidrovia Paraguai-Paraná, que com seus 3.440 quilômetros ligando o coração da bacia do Paraná ao oceano Atlântico, adquiriu importância a partir da assinatura do Tratado da Bacia do Prata, em 23 de abril de 1969, firmado pelos chanceleres de Argentina, Bolívia, Brasil, Paraguai e Uruguai, numa perspectiva de utilização cooperativa e solidária desse corredor de exportação. A Bolívia utiliza-se desse corredor por intermédio do Canal Tamengo, em Puerto Quijarro, província de Santa Cruz, na divisa com a cidade brasileira de Corumbá para escoar parte de sua produção.

A partir do ano 2000, a infraestrutura de transporte foi melhorada, sobretudo, no que se refere a integração dos diferentes corredores de transporte que passam pela Bolívia, planejados a partir da Iniciativa para a Integração da Infraestrutura Regional Sul-americana (IIRSA), um fórum de diálogo que tem por objetivo a promoção do desenvolvimento da infraestrutura de transportes, de energia e de comunicações sob uma perspectiva regional. Outro ponto a destacar é a recente implantação de uma rede de fibra ótica conectando as principais cidades da Bolívia. 
Apesar dos avanços, vale ressaltar, porém, que a infraestrutura interna boliviana ainda deixa a desejar. Dos quase 50 mil quilômetros de rodovias internas, menos da metade estão asfaltados.

Conforme notícia veiculada no sítio do jornal Valor Econômico ${ }^{5}$, é interesse do governo Evo Morales estatizar o bipartido sistema ferroviário da Bolívia. Segundo o ministro boliviano de Obras Públicas, Walter Deldadillo, a intenção do governo é criar uma empresa ferroviária estatal, a Empresa Boliviana de Ferrocarriles e, via financiamento chinês, completar a ligação ferroviária entre Santa Cruz de la Sierra e Cochabamba, o único trecho que falta para interligar o sistema ferroviário boliviano e, por extensão, o porto de Santos no Atlântico ao porto de Arica, no Pacífico.

Esses avanços, porém, devem ser objeto de estudo futuro, em um recorte temporal que abarque o período pós 1971 até o governo Evo Morales, passando pelo período neoliberal de Sanchéz de Lozada.

Sem negar o caráter subalterno da inserção boliviana na ordem do capital, fica nítido que esta sociedade também é tomada pelas mesmas contradições que o capital impõe a qualquer sociedade que controle e imprima seu ritmo de valorização territorial, utilizando-se para tal finalidade, a construção de caminhos na tentativa de dar unicidade ao território nacional.

Portanto, há uma história e, principalmente, uma práxis do Estado Nacional boliviano, que difere em grau, mas não na essência de ações e práticas de Estados Nacionais dito centrais do sistema do capital. O Estado boliviano é parte de um sistema interestatal da América do Sul, nos quais Estados se constituem e se desdobram por meio do contato, atrito e contraste uns com outros. Neste caso, Peru, Chile, Argentina, Paraguai e Brasil fazem parte do processo de constituição internacional/nacional da Bolívia.

\footnotetext{
${ }^{5}<$ http://www.valoronline.com.br/?online/internacional/13/6043955/bolivia-vai-estatizarferrovias>. Acesso em 13 jan. 2010.
} 


\section{REFERÊNCIAS BIBLIOGRÁFICAS}

ALEXANDRE, C. V. M. A política boliviana de nacionalização do petróleo e do gás. Observador on-line, Rio de Janeiro: IUPERJ, vol. 1 n 3, abril 2006. Disponível em: <http://observatorio.iuperj.br>. Acesso em: 3 de janeiro de 2010. ALVARADO, J. G. Las negociaciones comerciales de Bolivia com la Unión Europea, em el Alca y com Mercosur, in ARAÚJO, H. V. de. (org.). Os Países da Comunidade Andina. Vol. 1. Brasília: Fundação Alexandre de Gusmão: IPRI, 2004.

ANDRADE, E. O. Bolívia, 1964 - Os militares também golpeiam. Projeto História, São Paulo: EDUC, nº 31, p. 131 -146, jul/dez 2005.

. A Revolução Boliviana. São Paulo: Editora UNESP, 2007.

ARCE, O. D. O Paraguai Contemporâneo (1925 - 1975). In CASANOVA, P. G. (org.). América Latina: história de meio século. Vol. 1. Brasília: Editora Universidade de Brasília, 1988.

AYERBE, L. F. Estados Unidos e América Latina: a construção da hegemonia. São Paulo: Editora UNESP, 2002.

AZEVEDO, F. de. Um trem corre para o oeste. Obras Completas vol. XII, $2^{\text {a }}$ Ed. São Paulo: Melhoramentos, s.d..

BAKEWELL, P. A Mineração na América Espanhola Colonial. In: BETHELL, L. (org.). História da América Latina: América Latina Colonial. Vol. II, $2^{\text {a }}$ reimpressão. São Paulo: EDUSP; Brasília: Fundação Alexandre de Gusmão, 2008.

BANDEIRA, L. A. M. O expansionismo brasileiro e a formação dos Estados na Bacia do Prata. Rio de Janeiro/Brasília: Ed. Revan/Ed. Universidade de Brasília, 1985.

A guerra do Chaco. Revista brasileira de política internacional, Brasília: RBPI, vol. 41 no 1, janeiro/junho 1998. Disponível em: <http://www.scielo.br>. Acesso em 13 de dezembro de 2009.

. O Barão de Rothschild e a questão do Acre. Revista brasileira de política internacional, Brasília: RBPI, vol. $43 \mathrm{n}^{\circ} 2$, julho/dezembro 
2000. Disponível em: <http://www.scielo.br>. Acesso em 13 de dezembro de 2009.

BARROS FILHO, O. Bolívia: vocação e destino. São Paulo: Versus, 1980.

BARSOTTI, P. PERICÁS, L. B. (Org.) América Latina: história, idéias e revolução. São Paulo Xamã, 1998.

BASTOS, A. C. T. O Valle do Amazonas. $2^{\mathrm{a}}$ ed. São Paulo: Nacional, 1937.

BIEBER, L. E. A Guerra do Chaco e as relações brasileiro - bolivianas no período 1930 - 1945. Um caso de reorientação da política exterior do Brasil. In: ALBUQUERQUE, J. A. G. (org.). Sessenta anos de política externa brasileira (1930-1990): O Desafio Geoestratégico. São Paulo: Annablume/NUPRI/USP, 2000.

BLAKEMORE, H.O Chile da Guerra do Pacífico à Grande Depressão, 1880 1930. In: BETHELL, L. (org.). História da América Latina: De 1870 a 1930. Vol. V. $1^{\mathrm{a}}$ ed. $1^{\mathrm{a}}$ reimpressão. São Paulo: EDUSP; Brasília: Fundação Alexandre de Gusmão, 2008.

BLANES, J. Bolivia: Las áreas metropolitanas en perspectiva de desarrollo regional. Revista Eure. Vol. XXXII n 95. Santiago de Chile: 2006. Disponível em: <http://www.scielo.cl>. Acesso em 05 de março de 2009.

BOLÍVIA. Instituto Nacional de Estadística. Aspectos Geográficos. Disponível em<http://www.ine.gov.bo/html/visualizadorHtml.aspx?ah=Aspectos_Geografic os.htm>. Acesso em 14 out. de 2008.

BONILLA, H. O Peru e a Bolívia da Independência à Guerra do Pacífico. In: BETHELL, L. (org.). História da América Latina: Da Independência a 1870. Vol. III. $1^{\mathrm{a}}$ ed. $2^{\mathrm{a}}$ reimpressão. São Paulo: EDUSP; Brasília: Fundação Alexandre de Gusmão, 2009.

BRADING, D. A. A Espanha dos Bourbons e seu Império Americano. In: BETHELL, L. (org.). História da América Latina: América Latina Colonial. Vol. I. $2^{\mathrm{a}}$ ed. $2^{\mathrm{a}}$ reimpressão. São Paulo: EDUSP; Brasília: Fundação Alexandre de Gusmão, 2008.

BOCHICCHIO, V. R. Atlas Mundo Atual. São Paulo: Atual, 2003.

BRUIT, H. Burguesia Nacional e Internacionalismo do Capital, A Burguesia Chilena no Século XIX. In: BRUIT, H. (org.). Estado e Burguesia Nacional na América Latina. Campinas: Editora da UNICAMP/Ícone Editora, 1985. 
BUSHNELL, D. A Independência da América do Sul Espanhola. In: BETHELL, L. (org.). História da América Latina: Da Independência a 1870. Vol. III. $1^{\mathrm{a}}$ ed. $2^{a}$ reimpressão. São Paulo: EDUSP; Brasília: Fundação Alexandre de Gusmão, 2009.

CHASTEEN, J. C. América Latina: Uma história de sangue e fogo. Rio de Janeiro: Campus, 2001.

CHIAVENATO, J. J. A guerra do Chaco (leia-se petróleo). São Paulo: Brasiliense, 1979.

. Bolívia com a pólvora na boca. São Paulo: Brasiliense, 1981.

CHOQUE, R. "Os Aimarás e a questão colonial". In: BONILLA, H. (org.). Os conquistados: 1492 e a população indígena das Américas. São Paulo: Hucitec, 2003.

COLLIER, S. "O Chile da Independência à Guerra do Pacífico". In: BETHELL, L. (org.). História da América Latina: Da Independência a 1870. Vol. III. $1^{\mathrm{a}}$ ed. $2^{\mathrm{a}}$ reimpressão. São Paulo: EDUSP; Brasília: Fundação Alexandre de Gusmão, 2009.

COSTA, A. L. M. C. "Muitas Bolívias", in Revista Carta Capital, São Paulo: Ed. Confiança, ano XIV, nº 476, p. 34 - 35, 26 de dezembro de 2007.

COSTA NETO, C. Políticas Agrárias na Bolívia (1952 - 1979): Reforma ou Revolução? São Paulo: Expressão Popular, 2005.

COUTO E SILVA, G. Conjuntura Política Nacional: O poder Executivo \& Geopolítica do Brasil. 3ª Ed. Rio de Janeiro: José Olympio Editora, 1981.

DONGHI, H. História da América Latina. Rio de Janeiro: Paz e Terra, 1975.

DORATIOTO, F. Espaços nacionais na América Latina. São Paulo: Brasiliense, 1994.

DUSSEL, E. "Europa, Modernidade e Eurocentrismo" in LANDER, E. (org) A Colonialidade do Saber: Eurocentrismo e Ciências Sociais. Perspectivas Latino-americanas. Buenos Aires: CLACSO, 2005.

ELLIOTT, J. H. "A Conquista Espanhola e a Colonização da América", in BETHELL, L. (org.). História da América Latina: América Latina Colonial. Vol. I. $2^{\mathrm{a}}$ ed. $2^{\mathrm{a}}$ reimpressão. São Paulo/Brasília, EDUSP, Fundação Alexandre de Gusmão, 2008. 
FERREIRA, C. da C. B. C. O Tratado de Petrópolis e a Petrobrás: Uma análise das relações Brasil-Bolívia à luz da Teoria da Dependência. Dissertação de mestrado. Florianópolis: Departamento de Direito do CCJ/UFSC, 2007.

FERREIRA, M. R. A Ferrovia do Diabo. São Paulo: Melhoramentos, 2005.

GALLUP, J. L. GAVIRIA, A. LORA, E. Geografia é destino? São Paulo: Editora UNESP, 2005.

GARCIA, D. S. da C. Território e Negócios na "Era dos Impérios": Os Belgas na Fronteira Oeste do Brasil. Brasília: Fundação Alexandre de Gusmão, 2009.

GARCIA, M. del C. L. Proceso de urbanización, estructura productiva y empleo en las ciudades del eje economico de Bolivia. Miami: Latin American Studies Association XXII Internacional Congreso, 2000.

GERAB, K. RESENDE, M. A. A Rebelião de Tupac Amaru. São Paulo: Brasiliense, 1987.

GILL, S. Gramsci, Materialismo Histórico e Relações Internacionais. Rio de Janeiro: Editora UFRJ, 2007.

GUMUCIO, M. P. Breve historia contemporânea de Bolívia. México D.F.: Fondo de Cultura Economica, 1996.

HARDMAN, F. F. Trem-Fantasma. $2^{a}$ ed. São Paulo: Companhia das Letras, 2005.

HARVEY, D. Condição pós-moderna. 6ª ed. São Paulo: Edições Loyola, 1996. - A produção capitalista do espaço. $2^{\mathrm{a}}$ ed. São Paulo: AnnaBlume, 2006.

HEMMING, J. Fronteira Amazônica. São Paulo: EDUSP, 2009.

HYLTON, F. THOMSON, S. Revolutionary Horizons - Past and present in Bolivian Politics. London: Verso. 2007.

HOBSBAWM, E. J. A Era do Capital 1848 - 1875. Lisboa: Editoral Presença, 1975.

Nações e Nacionalismo desde 1780 - Programa, Mito e

Realidade. $4^{\circ}$ ed. São Paulo: Paz e Terra, 2004

HOFMEISTER, W. "Bolívia: a construção da democracia e a evolução do processo político", in ARAÚJO, H. V. de. (org.). Os Países da Comunidade Andina. Vol. 1. Brasília: Fundação Alexandre de Gusmão: IPRI, 2004. 
KLEIN, H. S. Bolívia: Do período pré-incaico à independência. São Paulo: Brasiliense, 1991. (Tudo é História: 137)

- "A Bolívia da Guerra do Pacífico à Guerra do Chaco, 1880 1932", in BETHELL, L. (org.). História da América Latina: De 1870 a 1930. Vol. V. $1^{\mathrm{a}}$ ed. $1^{\mathrm{a}}$ reimpressão. São Paulo/Brasília, EDUSP, Fundação Alexandre de Gusmão, 2008.

LANDER, E. "Ciências Sociais: Saberes Coloniais e Eurocêntricos", in LANDER, E. (org) A Colonialidade do Saber: Eurocentrismo e Ciências Sociais. Perspectivas Latino-americanas. Buenos Aires: CLACSO, 2005.

. "Marxismo, Eurocentrismo e Colonialismo", in BORON, A. A., AMADEO, J. GONZÁlEZ, S. (orgs.). A Teoria Marxista Hoje: Problemas e perspectivas. São Paulo, Expressão Popular, 2007.

LEWIS, P. H. "O Paraguai da Guerra da Tríplice Aliança à Guerra do Chaco, 1870 - 1932", in BETHELL, L. (org.). História da América Latina: De 1870 a 1930. Vol. V. $1^{\mathrm{a}}$ ed. $1^{\mathrm{a}}$ reimpressão. São Paulo/Brasília, EDUSP; Fundação Alexandre de Gusmão, 2008.

MACLEOD, M. J. "Aspectos da Economia Interna da América Espanhola Colonial: Mão-de-obra, Tributação, Distribuição e Troca", in BETHELL, L. (org.). História da América Latina: América Latina Colonial. Vol. II, $2^{\mathrm{a}}$ reimpressão. São Paulo: EDUSP; Brasília: Fundação Alexandre de Gusmão, 2008.

MAPA de la actual red ferroviaria de Bolivia. Disponível em: <http://www.umss.edu.bo/epubs/etexts/downloads/26/1.htm>. Acesso em 8 dez. de 2009 - adaptado.

MARIÁTEGUI, J. C. Sete ensaios de interpretação da realidade peruana. São Paulo, Expressão Popular/CLACSO, 2008.

MARTIN, A. R. Fronteiras e Nações. São Paulo: Contexto, 1992.

As Fronteiras internas e a "questão regional" do Brasil.

Tese de doutorado. São Paulo. Departamento de Geografia da FFLCH/USP. 1993.

Brasil, Geopolítica e Poder Mundial - o anti-Golbery. Tese de Livre docência. São Paulo: Departamento de Geografia da FFLCH/USP. 2007.

MARTÍNEZ ALIER, J. O ecologismo dos pobres. São Paulo: Editora Contexto, 2007. 
MATTOS, C. de M. A geopolítica e as projeções de poder. Rio de Janeiro: Biblioteca do Exército Editora, 1977.

- Uma geopolítica pan-amazônica. Rio de Janeiro:

Biblioteca do Exército Editora, 1980.

MARX, K. Manifesto do Partido Comunista. 6ª ed. São Paulo: Global, 1986.

MAURO, F. "Portugal e o Brasil: A Estrutura Política e Econômica do Império, 1580 - 1750", in BETHELL, L. (org.). História da América Latina: América Latina Colonial. Vol. I. $2^{\mathrm{a}}$ ed. $2^{\mathrm{a}}$ reimpressão. São Paulo/Brasília, EDUSP, Fundação Alexandre de Gusmão, 2008.

MELLO, L. I. A. A Geopolítica do Brasil e a Bacia do Prata. Manaus: Ed. Universidade do Amazonas, 1997.

Quem tem medo da Geopolítica? São Paulo: HUCITEC e EDUSP, 1999.

MERCADO, R. Z. Bolivia: El desarrolo de la Conciencia Nacional. Montevidéu: Editorial Dialogo, 1967.

. "Considerações Gerais Sobre a História da Bolívia (1932-

1971)", in CASANOVA, P. G. (org.). América Latina: história de meio século.

Vol. 2. Brasília: Editora Universidade de Brasília, 1988.

MIGNOLO, W. D. Histórias locais/Projetos globais: colonialidade, saberes subalternos e pensamento liminar. Belo Horizonte: Editora UFMG, 2003.

MIRANDA, E. E. Quando o Amazonas corria para o Pacífico. $2^{\mathrm{a}}$ ed. Petrópolis: Vozes, 2007.

MORAES, A. C. R. Bases da formação territorial do Brasil: o território colonial brasileiro no "Iongo" século XVI. São Paulo: Hucitec, 2000.

. Território e História no Brasil. $2^{\mathrm{a}}$ ed. São Paulo: Hucitec,

2005. (Geografia: Teoria e realidade: 48. Série "Linha de Frente").

. Geografia Histórica do Brasil: cinco ensaios, uma proposta e uma crítica. São Paulo: Annablume, 2009.

MORSE, R. M. "O Desenvolvimento Urbano da América Espanhola Colonial", in BETHELL, L. (org.). História da América Latina: América Latina Colonial. Vol. II, $2^{\mathrm{a}}$ reimpressão. São Paulo: EDUSP; Brasília: Fundação Alexandre de Gusmão, 2008.

NATIONAL GEOGRAPHIC. Atlas National Geographic: América do Sul. São Paulo: Abril, 2008. 
NOVAIS, F. A. Portugal e Brasil na Crise do Antigo Sistema Colonial (17771808). 8a ed. São Paulo: Hucitec, 2005.

OLIVEIRA, H. A. de. Política Externa Brasileira. São Paulo: Ed. Saraiva, 2005.

PERICÁS, L. B. BARSOTTI, P. (Org.). América Latina: história, crise e movimento. São Paulo: Xamã, 1999.

PFRIMER, M. H. A Guerra da Água em Cochabamba, Bolívia: desmistificando os conflitos por água à luz da geopolítica. Tese de Doutorado. São Paulo. Departamento de Geografia da FFLCH/USP. 2009.

PNUD. Em um momento de crisis, inflexión y cambio Transformaciones regionales en Bolivia. La Paz: Programa de las Naciones Unidas para el Desarrollo, 2003.

PRADO JUNIOR, C. Formação do Brasil contemporâneo. 23a Ed. São Paulo: Brasiliense, 1994.

PRODANOV, C. C. Cultura e Sociedade Mineradora: Potosi 1569 - 1670. São Paulo: Annablume, 2002.

QUIJANO, A. "Colonialidade do Poder, Eurocentrismo e América Latina", in LANDER, E. (org) A Colonialidade do Saber: Eurocentrismo e Ciências Sociais. Perspectivas Latino-americanas. Buenos Aires: CLACSO, 2005.

ROGRIGUES, T. Política e drogas nas Américas. São Paulo: EDUC/FAPESP, 2004.

SANTOS, L. C. V. G. O império e as repúblicas do Pacífico. Curitiba: Ed. UFPR, 2002.

SANTOS, M. A natureza do Espaço. São Paulo: EDUSP, 2002. Economia Espacial. São Paulo: EDUSP, 2003.

SENA, D. R. de. "O Estado do Acre: breve abordagem diplomática e militar", in Revista A Defesa Nacional, Rio de Janeiro: BIBLIEX, ano LXXXVIII, nº 793, p. $4-21$, mai/jun/jul/ago 2002.

TRAVASSOS, M. Projeção Continental do Brasil. $2^{\mathrm{a}}$ ed. São Paulo: Companhia Editora Nacional, 1935.

THIESSEN-REILY, H. "O nacionalismo caudilhista na Bolívia", in PAMPLONA, M. A., DOYLE, D. H. (orgs.). Nacionalismo no Novo Mundo. Rio de Janeiro: Record, 2008. 
THORP, R. "As Economias Latino-Americanas, 1939 - c. 1950", in BETHELL, L. (org.). História da América Latina: A América Latina Após 1930. Vol. VI. São Paulo/Brasília, EDUSP, Fundação Alexandre de Gusmão, 2005.

TOCANTINS, L. Formação Histórica do Acre. 2 Vol. $3^{\mathrm{a}}$ ed. Rio de Janeiro: Civilização Brasileira, 1979.

URQUIDI, V. Movimento Cocaleiro na Bolívia. São Paulo: Hucitec, 2007. VALLAUX, C. El suelo y el Estado. Madrid: Daniel Jorro, 1914.

VALOR ECONÔMICO. Bolívia vai estatizar ferrovias. Valor Econômico Online, 12 jan. 2010.2 Disponível em: <http://www.valoronline.com.br/?online/internacional/13/6043955/bolivia-vaiestatizar-ferrovias>. Acesso em: 13 jan. 2010.

VILAR, P. Ouro e moeda na história (1450 - 1920). Rio de Janeiro: Paz e Terra, 1981.

VIOTTI, M. L. R. "As relações Brasil-Bolívia sob o signo da cooperação energética (1930-1990)", in ALBUQUERQUE, J. A. G. (org.). Sessenta anos de política externa brasileira (1930-1990): O Desafio Geoestratégico. São Paulo: Annablume/NUPRI/USP, 2000.

VIZENTINI, P. G. F. "As relações Internacionais da Bolívia: Os desafios da Globalização e Integração", in: ARAÚJO, H. V. de. (org.). Os Países da Comunidade Andina. Vol. 1. Brasília: Fundação Alexandre de Gusmão: IPRI, 2004.

WACHTEL, N. A. "Os Índios e a Conquista Espanhola", in BETHELL, L. (org.). História da América Latina: América Latina Colonial. Vol. I. $2^{\mathrm{a}}$ ed. $2^{\mathrm{a}}$ reimpressão. São Paulo: EDUSP; Brasília: Fundação Alexandre de Gusmão, 2008.

WADDELL, D. A. G. "A Política Internacional e a Independência da América Latina", in BETHELL, L. (org.). História da América Latina: Da Independência a 1870. Vol. III. $1^{\text {a }}$ ed. $2^{\mathrm{a}}$ reimpressão. São Paulo/Brasília, EDUSP, Fundação Alexandre de Gusmão, 2009.

WASSERMAN, C. "Bolívia: História e identidade. Uma abordagem sobre cultura e a sociedade contemporânea", in ARAÚJO, H. V. de. (org.). Os Países da Comunidade Andina. Vol. 1. Brasília, Fundação Alexandre de Gusmão: IPRI, 2004. 
WHITEHEAD, L. "Bolívia", in BETHELL, L. e ROXBOROUGH I. (orgs.). A América Latina Entre a Segunda Guerra Mundial e a Guerra Fria. Rio de Janeiro: Paz e Terra, 1996. 